Chapman University

Chapman University Digital Commons

War and Society (MA) Theses

Dissertations and Theses

Spring 5-2019

\title{
Women in a Man's War: The Employment of Female Agents in the Special Operations Executive, 1940-1946
}

\author{
Cameron Carlomagno \\ Chapman University, carlo111@mail.chapman.edu
}

Follow this and additional works at: https://digitalcommons.chapman.edu/war_and_society_theses

\section{Recommended Citation}

Carlomagno, Cameron. Women in a Man's War: The Employment of Female Agents in the Special Operations Executive, 1940-1946. 2019. Chapman University, MA Thesis. Chapman University Digital Commons, https://doi.org/10.36837/chapman.000075

This Thesis is brought to you for free and open access by the Dissertations and Theses at Chapman University Digital Commons. It has been accepted for inclusion in War and Society (MA) Theses by an authorized administrator of Chapman University Digital Commons. For more information, please contact laughtin@chapman.edu. 
Women in a Man's War: The Employment of Female Agents in the Special Operations Executive, 1940-1946

\author{
A Thesis by \\ Cameron Davis Carlomagno
}

\author{
Chapman University \\ Orange, California
}

Wilkinson College of Arts, Humanities, and Social Sciences

Submitted in partial fulfillment of the requirements for the degree of

Masters of Arts in War and Society

May 2019

Committee in charge:

Jennifer Keene, Ph.D., Chair

Charissa Threat, Ph.D.

Kathryn Statler, Ph.D. 
This thesis of Cameron Davis Carlomagno is approved.

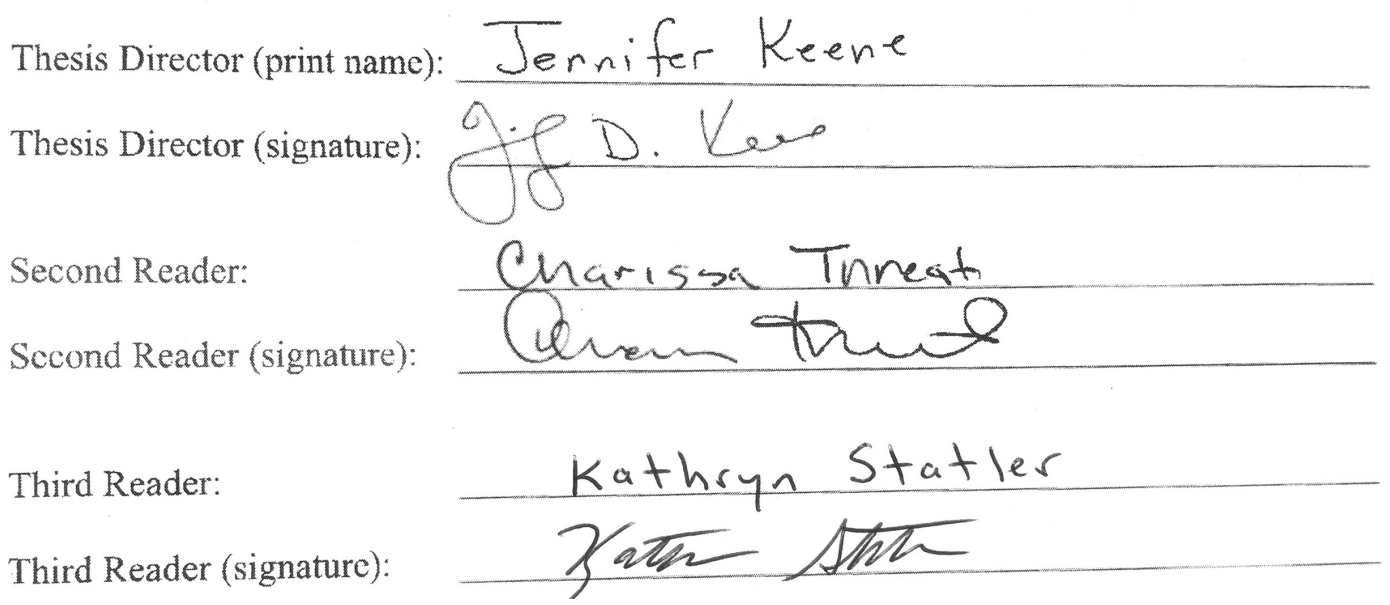

April 2019 
Women in a Man's War: The Employment of Female Agents in the Special Operations

Executive, 1940-1946

Copyright (C) 2019

by Cameron Davis Carlomagno 


\section{ACKNOWLEDGEMENTS}

This thesis has been the culmination of a few years of thought, research, and discussion, all of which would not have been possible without the support of my dedicated professors and friends.

I am particularly thankful for Dr. Jennifer Keene and Dr. Kathryn Statler, both of whom acted as advisors for this project at one point. Without your patience and guidance this project would not have developed in the ways it has over the years. I am eternally grateful for this, as well as their mentorship. I have had the great pleasure to learn from numerous professors from both Chapman University and the University of San Diego, without which I would not be the student nor scholar I am today.

Additionally, I am beyond grateful for my friends who have supported this long journey. I cannot properly express how much I valued their willingness to listen for hours as I worked through some of the more complicated aspects of this project. Their feedback and moral support, made all the difference. I only hope to one day repay the favor. 


\begin{abstract}
Women in a Man's War: The Employment of Female Agents in the Special Operations Executive, 1940-1946

by Cameron Davis Carlomagno

The Special Operations Executive (SOE) was established in 1940 under the directive of Winston Churchill to collaborate with resistance groups, divert enemy military advances and "set Europe ablaze!" As the world's armies marched across the globe once more, dozens of women found themselves deployed by the SOE to act as agents and combatants behind enemy lines; effectively challenging traditional gender roles in war. While World War II has often been perceived as a man's war, the direct and violent participation of women in various theaters of the war have been largely overlooked. Rather, women during WWII have been recalled as factory workers, nurses and mothers, all of which were crucial components in the war effort, but nonetheless conscribe to the traditional notions of the gendered war work hierarchy. In this hierarchy, superiority was defined as soldiering, but only for the men of a nation. As societal norms excluded women from this wartime role, nursing was the valued feminine position. Yet, female agents of the SOE were employed and valued for their claims to femininity as the organization co-opted stereotypes of womanhood to deceive enemy forces in occupied territory. This thesis explores the overarching question of what it means to be a woman in war, a perceived male-dominated sphere of influence. Even though research has expanded extensively on this important question, female SOE agents in France present a unique case study in which women were not only legitimized as combatants by a government, but were also recognized for the advantages of their femininity. Drawing
\end{abstract}


from SOE documentation, personnel files, and personal accounts from agents, this thesis illustrates the elite combatant status of female SOE agents in France. By tracking their experience from recruitment, training, war work, and imprisonment, reveals how both their actions and legal terminology defined these women as combatants, although unlawful. The fascination revolving around female agents has persisted over the past seventy-nine years since the inception of the SOE. That said, the way in which these elite women have been recognized has shifted from combatants to spies, a subtle but important distinction in terms of wartime gender roles. 


\section{TABLE OF CONTENTS}

ABBREVIATIONS ...................................................................................................ii

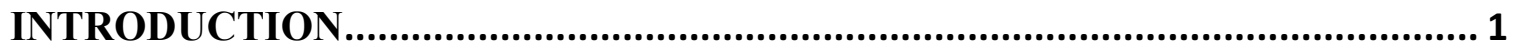

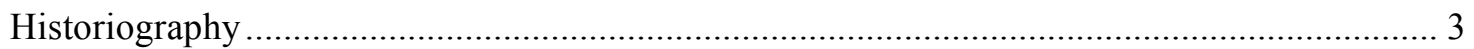

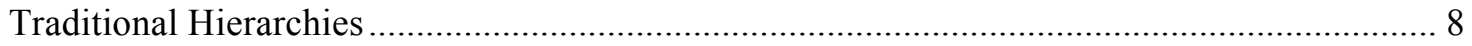

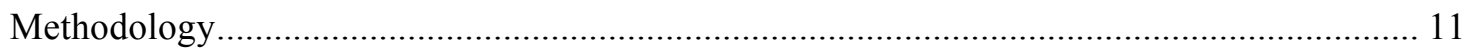

CHAPTER 1: GENDER, POWER, AND THE SOE ............................................ 16

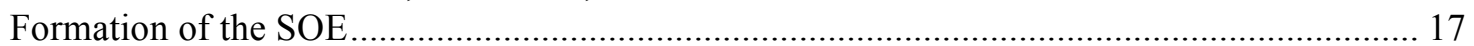

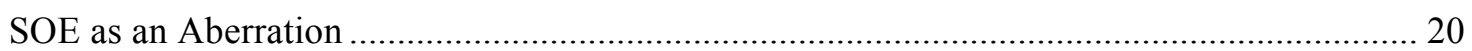

\section{CHAPTER 2: RECRUITMENT, TRAINING AND PERCEPTIONS OF}

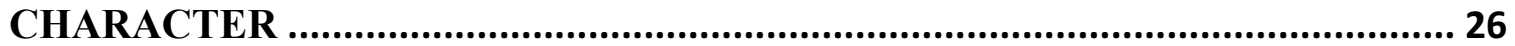

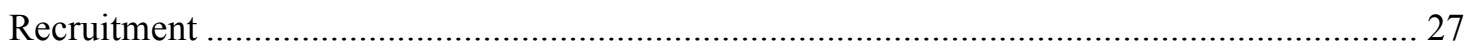

WAAFs, FANYs, and Military Professionals ............................................................... 30

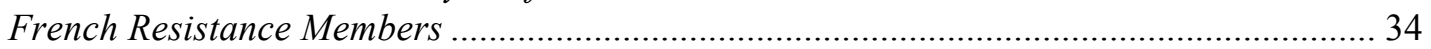

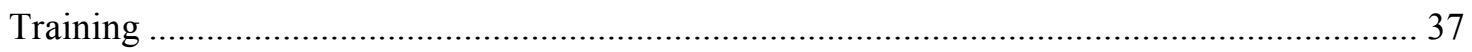

Actions in Relationship to Work................................................................................... 40

Perception of Character …………………………………………………………….... 43

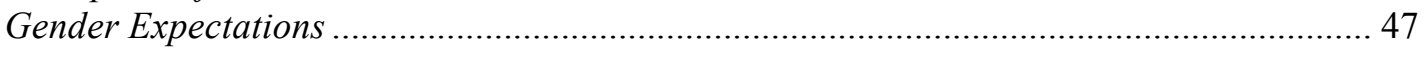

CHAPTER 3: WORKING IN THE SHADOWS ................................................... 53

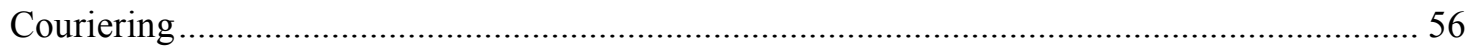

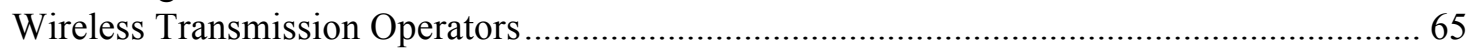

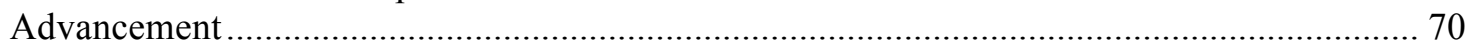

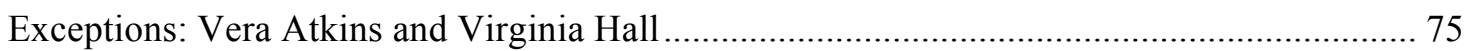

CHAPTER 4: COMBATANTS IN CAMPS: THE ARREST AND DEPORTATION

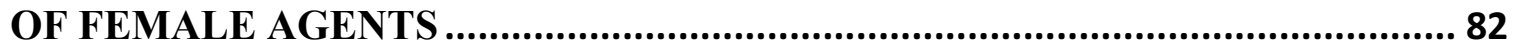

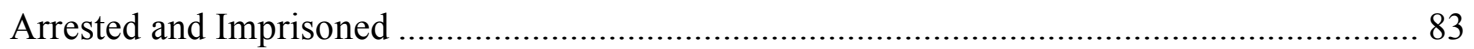

Stories from the Camps .................................................................................................. 95

\section{CHAPTER 5: AGENTS OR SPIES? MEMORY MAKING IN THE POST-WAR}

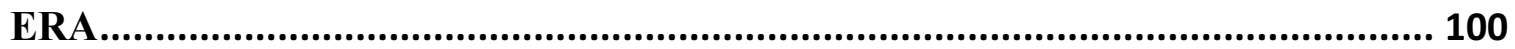

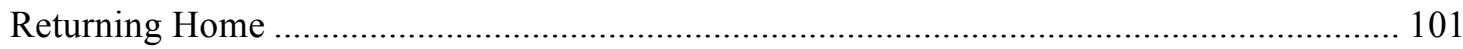

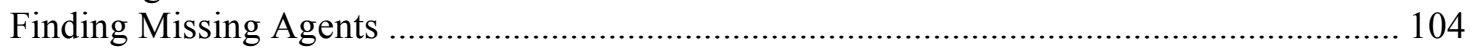

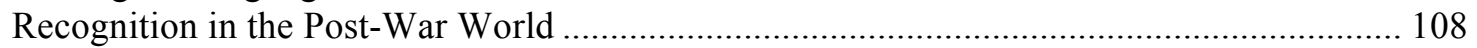

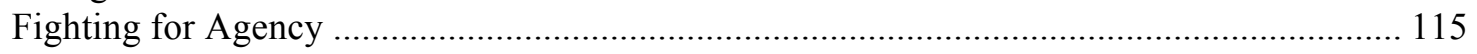

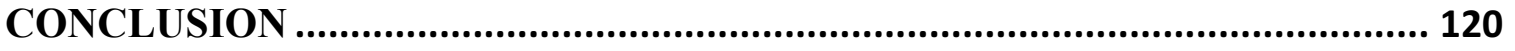

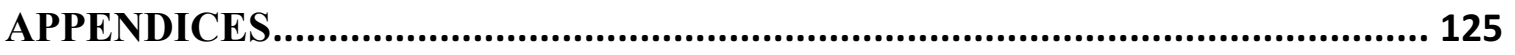

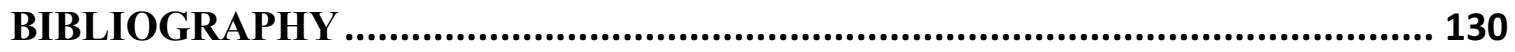




\section{ABBREVIATIONS}

$\begin{array}{ll}\text { EH } & \text { Electra House } \\ \text { FANY } & \text { First Aid Nursing Yeomanry } \\ \text { FLN } & \text { Front de Libération Nationale } \\ \text { FO } & \text { Foreign Office } \\ \text { JAG } & \text { Judge Advocate General } \\ \text { SIS } & \text { Secret Intelligence Service } \\ \text { SOE } & \text { Special Operations Executive } \\ \text { SS } & \text { Schutzstaffel } \\ \text { W/T } & \text { Wireless Transmission } \\ \text { WAAF } & \text { Women's Auxiliary Air Force } \\ \text { WO } & \text { War Office }\end{array}$




\section{INTRODUCTION}

What does it mean to be a soldier or a combatant? These two terms denote service, loyalty and courage in the face of death; all of which supposedly justify the superior position of this wartime role. The public, or popular, connotation of soldiering, however, differs from the legal terminology that defines an individual as a combatant. During the Second World War, the soldier was typified as a man in uniform serving and dying heroically on the battlefield for their nation. This popular memory does not typically include women acting behind enemy lines to subvert enemy forces. Yet, legally such women classified as combatants, although unlawful.

The Special Operations Executive (SOE), which was a British secret intelligence organization established in 1940 under the directive of Winston Churchill, employed forty women to participate in irregular warfare against the Axis powers in Occupied France and to help, as Churchill declared, "set Europe Ablaze!"” The deployment of men and women to France, referred to as the F Section — as well as other global warfrontsdeviated from traditional conceptions of gendered war work by recruiting women and engaging in irregular warfare. As these women traversed wartime France, they proved their merit as combatants to their peers as they took on extreme levels of risk, successfully carried out assignments, and in some cases engaged in the violence of war.

\footnotetext{
${ }^{1}$ The official number of female SOE agents part of the F Section, which was the codename for France, differs among historians. Generally, the number is usually thirty-nine or forty. This is because technically thirty-nine women were deployed to France prior to the liberation of the country in 1944. Yet, this research includes the fortieth, Vera Atkins, who became a high-ranking intelligence officer for the F Section at the London headquarters because of her extensive contribution to the war effort and close relationship to the agents deployed to France, as well as her work in the immediate post-war era. For a complete list of the F Section female agents see Appendix A. Sir Brooks Richards, "SOE and Sea Communications," in Special Operations Executive: A New Instrument of War, ed. by Mark Seaman (London and New York: Routledge, 2006), 33.
} 
While the accomplishments of these women can be attributed to the intense training under the SOE, ultimately, they were powerful components of the resistance effort in France because of their womanhood and their extraordinary character. By taking advantage of their femininity, these women more easily circumvented the enemy and carried out crucial missions that their male counterparts could not due to the suspicion brought on by their gender. Since men were expected to participate in the violence of war, they were more open to detection in comparison to female agents who capitalized on beliefs that women were incapable of operating in war. Classically perceived as the "beautiful souls" of the nation, a term coined by Just War and Feminist theorist Jean Bethke Elshtain, women were not automatically connected to active combat by officials on either side. If they served it would be as nurses or auxiliary forces, positions that male authorities deemed as comparable to the domestic sphere and adequately removed from the violence of war, both spatially and occupationally.

The official participation of these elite women in the war effort during WWII, effectively challenges traditional conceptions of the relationship between women and warfare. As combatants these women contradicted this socially prescribed male sphere of dominance; demonstrating both the invaluableness of their contributions and how femininity proved advantageous in irregular warfare in France. Through an examination of the employment of gender, war work and power dynamics, I argue that female SOE agents in France serve as a significant case-study to illustrate the ways that women operated in the violence of "men's wars." Challenging traditional gender hierarchies in war along the way. 


\section{Historiography}

What does it mean to be a woman in war? This is a long-debated question regarding the relationship between women and war that scholars have more recently began to dismantle; a question that is at the center of this thesis. Prior to the 1980s, this topic remained relatively understudied, but since has become a far more broadly evaluated relationship. Earlier gender scholars focused on properly explaining wartime gender dynamics - mainly the continual subordination of women to men during warmore recent historical literature has expanded upon this topic by demonstrating the ways in which traditional conceptions of the separation of women and war. This is a trend that this research follows, providing a unique case study to illustrate the continual contribution of women in war by taking up irregular positions in war and the ways in which their femininity became a powerful tool.

Just War ethics and feminist theorist Jean Bethke Elshtain was a prominent scholar in the overarching field of gender and warfare, publishing her book Women and War in 1987. Although written more like a narrative, Elshtain critically examines her own experiences to dissect the relationship between women and war. Her greatest contribution stemmed from her conceptualization of the "Just Warrior" and "Beautiful Soul" dynamic to explain societal perceptions on gender norms during war. ${ }^{2}$ Elshtain elaborates on such designations by noting that "Men fight as avatars of a nation's sanctioned violence. Women work and weep and sometimes protest with the frame of discursive practices that turn one out, militant mother and pacifist protestor alike, as the collective 'other' to the male warrior." ${ }^{3}$ Elshtain masterfully notes the role of cumulative

\footnotetext{
${ }^{2}$ Jean Bethke Elshtain, Women and War (New York: Basic Books, 1987).

${ }^{3}$ Elshtain, Women and War, 3-4.
} 
memory in Western society to explain the division between men/war and women/peace.

Further explaining that only "real men and women...take on the personas of Just

Warriors and Beautiful Souls" respectively, she notes the emasculation and defeminizing of those who deviate from these roles. Women in War ultimately acted as a first step in challenging the notion that all embrace societally assigned gender roles in war, points which this research strives to expand upon. As Elshtain was one of the early contributors to feminist theory regarding war and women's place in war-whether as warriors, mothers, or protestors - she does not come to a definitive conclusion other than the need to reexamine ideas of the war/male and peace/female dichotomy. The experience of female agents in the SOE demonstrates the myriad roles women fill during war, contesting the idea that there is a "rightful" place in war for women.

Laura Lee Downs' essay "War work" in The Cambridge History of The First World War challenges the idea that women gained political and social status through wartime work during World War I. Throughout this chapter, Downs strives "to find a new way to discuss what did and did not change during the First World War." contests traditional definitions of work, asserting that domestic work situations and caring for a family classifies as war work. Although women became part of crucial wartime industrial enterprises, Downs demonstrates that most women only experienced a temporary occupational shift during the war and returned to their pre-war domestic status following the end of World War I. Similarly, this thesis demonstrates that regardless of their challenges to wartime hierarchies, SOE women received little permanent change in social status.

\footnotetext{
${ }^{4}$ Laura Lee Downs, "War Work" in The Cambridge History of The First World War, volume III, edited by Jay Winter (United Kingdom: Cambridge University Press, 2016), 76.
} 
Kimberly Jensen is another WWI historian who explores the role of women in war in her book Mobilizing Minerva. By looking at armed women, nurses, and female physicians, Jensen argues that "By raising questions of the relationship of women's service to the state and their civic and professional status, by challenging the script of the Protector and the Protected, by seeking to transform the military itself, women challenged policy makers' assumptions and dependence on women's support and the way they conducted the war." Through each of these groups, Jensen illustrates the ways in which women were put in considerable danger during times of war-whether by the enemy or the men of their own nation — disrupting traditional ideas that women are removed from the violence of war for their protection. Rather, Jensen demonstrates how women were both physically and verbally threatened, oftentimes by their fellow countrymen. The women who bore arms during WWI, on the homefront and on the battlefield, were deemed as sexually deviant by men who sought to maintain the gender divide in war. If female combatants were not actually women, they did not challenge traditional gender norms. This thesis contributes to Jensen's challenge of the protected and the protector dynamic in war by demonstrating the inordinate risk that female agents took during WWII. This research, however, deviates by focusing on an example where female combatants were valued for their femininity.

MRD Foot's book, SOE: An Outline History of the Special Operations Executive 1940-1945, is the first official history of the Special Operations Executive. Pulling from official SOE documents, Foot creates an overall picture of the background of the agency and its effectiveness during World War II. The more important role that Foot plays,

\footnotetext{
${ }^{5}$ Kimberly Jensen, Mobilizing Minerva American Women in the First World War (Urbana, Chicago, and Springfield: University of Illinois Press, 2008), xiii.
} 
however, is that of memory-maker. Since Foot's goal was to provide a narrative of the SOE as a wartime institution, the women of the organization were placed in the background, which subsequently shaped many of the narratives surrounding the female agents. By only mentioning them in passing, Foot upholds traditional perspectives that women acted as noncombatants in war, especially in relation to the men at the SOE. Conversely, this thesis will focus primarily on the collective female experience in the $\mathrm{F}$ Section. Moreover, I challenge Foot's negative review of agents, primarily Odette Sansom, and show that they were elite women who accomplished extraordinary acts under immense pressure.

Juliette Pattinson is one of the leading scholars researching the female agents of the Special Operations Executive. In her book Behind Enemy Lines: Gender, Passing and the Special Operations Executive in the Second World War, Pattinson explores the role of gender in the SOE-comparing the female and the male experiences—in hopes to "extend the debate about wartime gender relations." By progressing through the various stages of recruitment, training and deployment, Pattinson explores how gender contributes to the ability for SOE agents to pass in wartime France. Noting the varying definitions of passing, Pattinson depicts the ac of passing as "the term used to refer to the process whereby individuals of one race, gender, class, religion or sexuality attempt to appropriate the characteristics of the 'Other' and desire not to be recognized as different." ${ }^{, 7}$ As such, Pattinson contributes to the larger debate about the role of women in war, by demonstrating the ways in which gender determined how an agent passed as a

\footnotetext{
${ }^{6}$ Juliette Pattinson, Behind Enemy Lines: Gender, Passing and the Special Operations Executive in the Second World War (Manchester and New York: Manchester University Press, 2007), 10.

${ }^{7}$ Pattinson, Behind Enemy Lines, 15.
} 
French native. Pattinson's work is particularly important because unlike previous sources, she "examines the one British organisation which did deploy women in a combat situation and by so doing potentially destabilized conventional gender norms." ${ }^{\prime 8}$ Although Pattinson's exploration of the impact of gender on passing for female agents is an important concept of consideration, this research deviates from Pattinson's by primarily focusing on the ways in which these women contradicted traditional ideas about gendered war work hierarchies.

Finally, Roderick Bailey has contributed to SOE literature by deviating from the traditional historiographies of earlier scholars, like Foot. While his research centers on the SOE in the Balkans, Bailey's book Forgotten Voices of the Secret War: An Inside History of Special Operations during the Second World War provides a personal account of the wartime experiences of SOE agents that operated across the globe. Compiling the oral testimonies of male and female agents of the SOE taken by the Imperial War Museum, Bailey "seeks to underline both the complexities of SOE and the realities of behind-the-lines work, from the terrible risks run to the appalling reprisals on occupied populations which agents' actions could precipitate." ${ }^{.9}$ Although Bailey does not specifically focus on women in the SOE, he seamlessly integrates their experiences into the pages of his book. Moreover, the structure of this work allows for the voices of agents to speak for themselves, which both creates a unique perspective of the wartime experiences of agents and shows the ways in which women fit into the larger narrative. Ultimately, it is Bailey's methodological approach, utilizing oral histories, that makes this

\footnotetext{
${ }^{8}$ Pattinson, Behind Enemy Lines, 11-12.

${ }^{9}$ Roderick Bailey, Forgotten Voices of the Secret War: An Inside History of Special Operations During the Second World War (Great Britain: Ebury Press, 2009), vii.
} 
source important to my research project. It demonstrates the various ways to rely on the limited primary sources to construct an argument that contributes to the discussion about women and war.

\section{Traditional Hierarchies}

Gender and war work are interrelated subjects, which aid in the understanding of gender power dynamics. According to R.W. Connell, "gender can be defined as the ways in which the 'reproductive arena,' which includes 'bodily structures and processes of human reproduction,' organizes institutions." ${ }^{10}$ Connell's theory applies biological definitions of gender to resulting social norms and practices, asserting that "masculinity is an identifiable set of practices that occur across space and over time and are taken up and enacted collectively by groups, communities, and societies."11 Mimi Schippers furthers this understanding by stating, "social practice, in all its forms, from embodied interaction to child raising, sexual activity, developing and executing policy, passing legislation, producing television programming, and invading countries, is the mechanism by which masculinities and femininities, as part of a vast network of gender meanings, come to organize social life." ${ }^{12}$ The social practices, values, and norms in relation to authority that determine one's status were aspects that female SOE agents used to their advantage.

Connell's theory also assumes that despite the existence of "multiple masculinities," there is a dominant one which acts as the ideal form which in turn justifies

\footnotetext{
${ }^{10}$ Mimi Schippers, "Recovering the Feminine Other: Masculinity, Femininity, and Gender Hegemony," Theory and Society 36, No. 1 (February 2007): 86.

${ }^{11}$ Schippers, "Recovering the Feminine Other," 86.

12 Schippers, "Recovering the Feminine Other," 92.
} 
the subordination of all other gender behaviors. ${ }^{13}$ Connell refers to this as hegemonic masculinity, in "“which guarantees (or is taken to guarantee) the dominant position of men and the subordination of women." ${ }^{, 14}$ As the ideal, hegemonic masculinity dominates both femininity and all other masculinities that do not fit the paradigm.

As a result, the gender hierarchy consists of hegemonic masculinity, inferior masculinities, hegemonic femininity, and inferior femininities. ${ }^{15}$ While Schippers describes the hegemonic masculine as "the qualities defined as manly that established and legitimate a hierarchical and complementary relationship to femininity..." she notes that "Hegemonic femininity consists of the characteristics defined as womanly that establish and legitimate a hierarchical and complementary relationship to the hegemonic masculinity..." descriptions automatically become part of the inferior.

In Great Britain, the wartime hegemonic characteristics were a culmination of attributes informed by World War I, the poverty of the Great Depression, and the requirements of civic-duty. According to Sonya O. Rose, author of Which People's War?, hegemonic masculinity during this period "combined...two potentially contradictory masculinities — one exemplified by the soldier-hero, and the other generated from the anti-heroic mood of the inter-war period and fashioned in opposition to the hyper-masculine German other. But to perform it successfully men had to be in uniform."

\footnotetext{
${ }^{13}$ Schippers, "Recovering the Feminine Other," 85.

${ }^{14}$ Schippers, "Recovering the Feminine Other," 87.

${ }^{15}$ See Appendix B: Traditional Gender-War Work Hierarchy.

${ }^{16}$ Schippers, "Recovering the Feminine Other," 94.

${ }^{17}$ Sonya O. Rose, Which People's War? National Identity and Citizenship in Wartime Britain 1939-1945 (Oxford: Oxford University Press, 2003), 195.
} 
Hegemonic femininity during World War II was far more complicated because it required the balance between participation in the public sphere, the maintenance of the private sphere, and conveying physical glamour. ${ }^{18}$ Finding a middle ground was difficult. Wartime participation — whether by joining the work force or the military—made mothering difficult. There was also an expectation to remain physically attractive, without being overly sexual. If women focused too much on mothering they would be accused of being unpatriotic, and if they became too involved with the war effort they threatened masculine authority. In either case, a misstep would impact their place in the traditional gender hierarchy.

As seen through the characterizations of hegemonic traits in WWII Britain, work played a significant role in designating one's status. For men, military service was key; "Lacking a military unform [sic], working men stressed the heroic features of their masculinity. They drew upon both a language of military battle and a language of working-class manhood in their self-representations. ${ }^{, 19}$ Without the symbolic value of a military uniform, men replaced it with rhetoric and other significant values in British society. For women, nursing was the epitome of wartime hegemonic femininity. War work further legitimized the traditional hierarchy because of the exclusion of women from military service. When women did enter the military sphere, however, their claims to femininity were largely questioned. For instance, Sonnie Hale, a variety actor quoted in Woman's Own—a British magazine—stated, "'You may be in one of the women's

\footnotetext{
18 "In World War II Britain women and men could enact good citizenship in numerous ways, but for women, sexuality and motherhood were fundamental." Rose, Which People's War?, 118.

${ }^{19}$ Rose, Which People's War?, 195.
} 
services and therefore in uniform. If you are remember there is no need to strut and shout around. There is no need to ape men.",20

Contrary to popular belief, World War II did not permanently nor significantly alter this traditional hierarchy. ${ }^{21}$ Although women were more readily accepted into the public sphere, filling the void left by men-turned-soldiers, they were largely still subjected to masculine power. That said, the demands of WWII did allow for the creation of the Special Operations, which in turn provided the opportunity for this traditional hierarchy to be contested. More importantly, as will be seen throughout this research, this unique space that allowed for the operation of female combatants challenges longstanding conceptions about the relationship between women and war.

\section{Methodology}

The SOE created an astounding opportunity to challenge traditional notions of gender dynamics, but its secretive nature prevented discovery of this face. The organization went to elaborate extents to conceal its inner workings during wartime, and shortly after the war ended the SOE was disbanded. With its dissolution, many of the documents detailing its actions and agents were destroyed, altered or restricted. According to Vera Atkins, a female F Section intelligence officer, the SOE "kept records to an absolute minimum and only for direct operational purposes and not for with any regard to future historians or post war inquiries. That was never in anyone's mind that

\footnotetext{
${ }^{20}$ Rose, Which People's War?, 123.

${ }^{21}$ For further information see, Laura Lee Downs, "War Work" in The Cambridge History of The First World War, volume III, edited by Jay Winter (United Kingdom: Cambridge University Press, 2016); Karen Anderson, Wartime Women: Sex Roles, Family Relations, and the Status of Women in World War II, (Westport, CT: Greenwood Press, 1981); D'Ann Campbell, Women at War with America: Private Lives in a Patriotic Era, (Cambridge: Harvard University Press, 1984); and Ruth Milkman, Gender At Work: Dynamics of job Segregation by Sex during World War II, (Urbana: University of Illinois Press, 1987).
} 
there would be authors and similarly interested people of post-war histories, that was never in anyone's mind." 22 Rather than keeping meticulous files, members at SOE headquarters "[saw] that every scrape [of intelligence] was under lock and key, or destroyed..." ${ }^{23}$ Whether due to potential security risks or lack of forethought, the poor record keeping of the SOE poses a serious issue in reconstructing the full picture of agents' lives.

What documentation remains has only recently become available to the public. Many of the government documents were released in the early 2000s, which has two significant draw backs. First, that there are fewer sources available that can be used to double check information both in the files and in other secondary sources. ${ }^{24}$ Second, as few female agents took it upon themselves to detail their lives in the SOE, early scholars acted as memory-makers. Foot was the official SOE historian, commissioned by the British government to write the history of the organization. As a result, Foot's 1966 work significantly impacted the conceptions of female agents and their contributions to the war effort. It was difficult to argue against his perspectives without access to the documents. Moreover, Foot crafted an image of these women that has existed for nearly fifty years.

\footnotetext{
${ }^{22}$ Vera May Atkins, interviewed by Conrad Wood, Imperial War Museum, January 6, 1987, interview 9551.

${ }^{23}$ Vera May Atkins, interviewed by Conrad Wood, Imperial War Museum, January 6, 1987, interview 9551.

${ }^{24}$ This consequence is seen in William Stevenson's significantly fabricated biography of Vera Atkins, Spymistress: The Life of Vera Atkins, the Greatest Female Secret Agent of World War II, which to the unknowing reader comes off as a fantastical account of spying during WWII. Without the ability to factcheck, Stevenson's book could easily drift into the popular image of female SOE agents. Stevenson's book was featured in a Vanity Fair article, "Five Badass Female Spies Who Deserve Their Own World War II Movie," which used his book as the authority for Vera Atkins, illustrating how easily false narrative can make it into the public view. Luckily since the book was published in 2007, scholars were able to more easily disprove Stevenson's work as a credible source. William Stevenson, Spymistress: The Life of Vera Atkins, the Greatest Female Secret Agent of World War II (New York: Arcade Publishing, 2011); Erika Jarvis, "Five Badass Female Spies Who Deserve Their Own World War II Movie," Vanity Fair, 25 November 2016, https://www.vanityfair.com/hollywood/2016/11/allied-world-war-2-female-spy-movies.
} 
This research specifically depends on the personnel files available through the National Archives in Kew. These files contain a collection of documents related to individual SOE agents that survived following the close of the organization in 1946, files ranging from fifty to over three-hundred. Each agent has a personnel file, however the number of documents in each file depends on both the length of an agent's service in the SOE and knowledge of the agent's actions while in the field. Since there was limited communication between the homefront in London and the battlefield in France, it was difficult for members at Headquarters to ascertain the specific movements and experiences of an individual agents. This was further complicated when an agent was arrested or killed, because the SOE had to piece together the information about the missing agent based on witness accounts and other indirect sources, such as unclear transmissions sent from the field. In comparison, the agents who returned were debriefed and provided a personal recollection of their experiences, which were then placed in their personnel file. In some unique cases, such as Noor Inayat-Khan who was arrested in France and executed in Germany, the SOE gained significant information regarding her imprisonment from post-war captured Gestapo guards' interrogations. Overall, the personnel files include information regarding the recruitment, training, and deployment of agents, as well as memorandums recommending an agent for an award. Furthermore, some files contain letters from family members, wireless transmission notes, mission details, and newspaper clippings.

The recommendation for awards records are also particularly useful in understanding the accomplishments of female agents and the weight of gender in determining commendations. While some of these memorandums provide the minimal 
requirement for the approval of the award, others elaborate by offering detailed testimonials. Despite the variation, the files provide accounts of the agents' war record and demonstrate what actions were valued by both $\mathrm{SOE}$ and British government officials. As will be explored in the final chapter, these records also reveal the eventual devaluation of women's participation in war in the post-war period.

The way in which these documents, and the people authoring them, choose to describe, support, praise, and disavow these female agents makes them invaluable sources. The gendered language utilized throughout these documents is vital. Not only does the word choice impact gender perception in the SOE, but the evolution of language also illustrates the significance of war work. Generally, the documents following the initial training reports highlight the importance of the contribution of these women. For the few female agents that survived the war and were recognized in the post-war world, the level of publicity given shows the shift back to traditional gender norms.

Although there are considerable issues regarding the government documents, they nevertheless provide important information that is not available in other forms. Collectively, they provide a full picture regarding the wartime experience of these women - many of whom did not live on to nor chose not to write their own perspectiveand their relationship with the larger organization.

Oral histories and memoirs are two other sources utilized in this research, although there are far fewer in number. These types of documentation are highly debated among historians because of the questionable accuracy of such sources. Historians primarily cite the potential problems of self-censorship and the fallibility of memory. ${ }^{25}$

\footnotetext{
${ }^{25}$ For further information regarding this debate and the use of oral histories and memoirs see, Peter Burke, "History as Social Memory" in The Collective Memory Reader, ed. by Jeffrey K. Olick, Vered Vinitzky-
} 
That said, as bias seems to be the greatest concern, arguably all sources present a certain bias. The personnel files, for instance, are terse and only provide information deemed important at the time. More importantly, oral histories and memoirs are crucial in this thesis not only because they help fill the gaps in information left by the personnel files, but also because they act as a form of agency for the female agents. As will be explored in the final chapter, the ability for these women to participate in the shaping the collective memory became crucial to them.

Collectively, these sources illustrate the complex wartime experiences of female $\mathrm{F}$ Section agents, and how they negotiated their gender and war work in a man's war. Conceptions of gendered war work altered power dynamics within the SOE, ultimately allowing for the women at the bottom of the hierarchy to either gain power within their designated space or to elevate their status as a result of their contributions during the war.

Seroussi, and Daniel Levy (Oxford: Oxford University Press, 2011), 189-192; Marion A. Kaplan, "Revealing and Concealing: Using Memoirs to Write German-Jewish History," in Text and Context: Essays in Modern Jewish History and Historiography in Honor of Ismar Schorsch, ed. Eli Lederhendler and Jack Wertheimer (New York: Jewish Theological Seminary of America, 2005), 383-410. 


\section{CHAPTER 1: GENDER, POWER, AND THE SOE}

"Set Europe ablaze!"1 What did Winston Churchill's famous words regarding the Special Operations Executive mean? Churchill was plausibly feasibly alluding to the hope that the organization would be able to catch the Axis powers off-guard through its use of irregular warfare. ${ }^{2}$ If so, Churchill overestimated the effectiveness of the SOE, because the SOE was never meant to be a force that could single-handedly topple the Axis powers. Churchill's statement can also be interpreted in a more metaphorical way. Rather than literally burning through Europe, the SOE figuratively singed the social standards that governed Europe. Unintentionally, the SOE challenged several presumptions regarding women and war. The organization operated outside the norm in two ways, through irregular warfare practices and by drawing women into direct participation of war. Thus, in this unique time and space, the SOE challenged longestablished gender power dynamics.

It would be a mistake to assume that traditional gender power dynamics disappeared in the SOE, but the distinctive mission of the SOE allowed for a slight shift. This chapter will first give a brief introduction and evaluation of how the SOE utilized

\footnotetext{
${ }^{1}$ Sir Brooks Richards, "SOE and Sea Communications," in Special Operations Executive: A New Instrument of War, ed. by Mark Seaman (London and New York: Routledge, 2006), 33.

${ }^{2}$ Sources differ on the definition of irregular warfare, many of which have focused on the post-World War II era. Colin S. Gray confirms the ambiguity in definining irregular warfare by stating, "We think we can improve our understanding of a subject as diffuse and richly varied as irregular warfare and insurgency by hunting for the most precise definition and subdefinitions. The results all too often are official definitions that tend to be encyclopaedic and are utterly indigestible." While Gray highlights the ways in which irregular and regular warfare are similar in nature, he does provide a few distinctive characteristics of irregular warfare, one of which being "Irregular warfare is warfare waged in a style, or styles, that are nonstandard for the regular forces at issue. The enemy is unlikely to be in the service of a state." This flexible and simple understanding of irregular warfare is useful for this research as it highlights the opposition of this mode of waging war from traditional methods and illustrates the flexibility of the method, which the SOE used to establish their own doctrine of irregular warfare. Colin S. Gray, "Irregular Warfare: One Nature, Many Characters,” Strategic Studies Quarterly 1, no. 2 (December 2007): 37; Ibid., 43.
} 
women, largely the basis for an alternative form of gender power dynamics. Additionally, this chapter strives to unpack the traditional gendered war work hierarchy and compare it to a model more applicable with the SOE.

\section{Formation of the SOE}

Wary of German military capabilities in the late-1930s, the British government devised new offensive and defensive means to subvert enemy forces. ${ }^{3}$ The organization was starting almost from scratch, MRD Foot asserted that "by 1938 the days of irregular warfare as a normal tactic of imperial expansion and defence were past, and half forgotten; no organization for conducting it survived, and there was no readily available corpus of lessons learned or of trained operators in this field." At first, three separate organizations - the Secret Intelligence Service (SIS), the Foreign Office (FO) and the War Office (WO) — established individual branches focused on researching various subversive techniques. ${ }^{5}$

Founded in 1909, the SIS specialized in gathering intelligence and in April 1938 formed Section IX, later known as Section D. ${ }^{6}$ The head of the SIS, Admiral Sir Sinclair, tasked Major L. D. Grand, an army officer, to "look into the theory of secret offensives: how could enemies be attacked, otherwise than by usual military means?"7 As war had yet to break out, Grand was left to theorize different scenarios that could hinder the Nazis. For instance, Grand “[thought] over sabotage, labour unrest, inflation, anything

\footnotetext{
${ }^{3}$ William Mackenzie, The Secret History of the SOE: The Special Operations Executive 1940-1945 (Great Britain: St. Ermin's Press, 2000), 3.

${ }^{4}$ M.R.D. Foot, SOE in France: An Account of the Work of the British Special Operations Executive in France 1940-1944 (London: Frank Cass, 2004), 3.

${ }^{5}$ David Stafford, Britain and European Resistance, 1940-1945: A survey of the Special Operations Executive, with Documents (Toronto: University of Toronto Press, 1980), 19.

${ }^{6}$ Stafford, Britain and European Resistance, 1940-1945, 20.

${ }^{7}$ Foot, SOE, 11.
} 
else that could be done to weaken an enemy, and if he could he was to make outline plans for them." ${ }^{\prime \prime}$

In addition to Grand's research, the FO contributed to plans of sabotageparticularly through propaganda. The organization "remembered that Lord Northcliffe, the newspaper magnate, had had great successes in 1917-18 in corrupting the morale of the German army by through propaganda." ${ }^{99}$ Continuing Northcliffe's ideas of propaganda, the FO recruited Canadian Sir Campbell Stuart to closer analyze the impact of propaganda on national morale, as well as how it could be systematized and employed. ${ }^{10}$ This new branch became known as "EH, named after Electra House on the Embankment where it worked under Sir Campbell Stuart (so it was also sometimes called CS). $" 11$

The last of the agencies was the War Office, which possessed a small research section called GS(R) - later known as MI(R). This branch was tasked "to study the practice and lessons of actual warfare." ${ }^{, 2}$ Yet, the focus of research did not turn towards irregular warfare until December 1938 when Lieutenant Colonel J. F. C. Holland was appointed to the division. ${ }^{13}$ His military experiences in Ireland, where irregular warfare tactics had been used by the Irish Republican Army (IRA), as well as his fascination with this mode of warfare, Holland made particularly suited for this position. ${ }^{14}$

\footnotetext{
${ }^{8}$ Foot, $S O E, 11$.

${ }^{9}$ Foot, $S O E, 10$.

${ }^{10}$ Foot, $S O E, 10$.

${ }^{11}$ M.R.D. Foot, "Was SOE Any Good?" Journal of Contemporary History 16, no.1 (1981): 167. http://www.jstor.org.libproxy.chapman.edu/stable/260622.

${ }^{12}$ Mackenzie, The Secret History of the SOE, 8.

${ }^{13}$ Mackenzie, The Secret History of the SOE, 8.

14 "Major J. C. F. Holland's career was already impressive. During the First World War he had been transferred to the Royal Flying Corps and was awarded the Distinguished Flying Cross. His service also included a period in Ireland during the 'Troubles'." Quoted in Mark Seaman, "'A New Instrument of War'
} 
While each of these organizations contributed in significant ways to Britain's conceptualization of irregular warfare, they were only stepping stones to the creation of the SOE. It was not until the collapse of France in 1940, and the regular army's defeat and evacuation from Dunkirk that these three sub-divisions were brought together to be "co-ordinated under a single minister." ${ }^{15}$ On July 1, 1940 Churchill's War Cabinet consented to the consolidation of these three sub-branches into one overarching organization. ${ }^{16}$ The following day Hugh Dalton, the first head of the SOE, wrote to Lord Halifax stating that:

What is needed is a new organization to co-ordinate, inspire, control and assist the nationals of the oppressed countries who must themselves be the direct participants. We need absolute secrecy, a certain fanatical enthusiasm, willingness to work with people of different nationalities, complete political reliability. ${ }^{17}$

With such a sweeping goal in mind, Dalton proposed pulling from a variety of methods, "including industrial and military sabotage, labour agitation and strikes, continuous propaganda, terrorist acts against traitors and German leaders, boycotts and riots." ${ }^{18}$ Although overly optimistic about the amount of resources that this new organization would receive, Dalton set out to reinvigorate Britain's use of irregular warfare.

Ironically the creation of the SOE was handed over to the same man who failed to secure peace prior to the outbreak of WWII, Neville Chamberlain. Following his resignation as Prime Minister in May, Chamberlain remained within the government as Lord President of the Council. In the last days of his life, he worked to draw up what

The origins of the Special Operations Executive, in Special Operations Executive: A New Instrument of War, ed. by Mark Seaman (London and New York: Routledge, 2006), 10.

${ }^{15}$ Foot, SOE, 18.

${ }^{16}$ Pattinson, Behind Enemy Lines, 2.

${ }^{17}$ Foot, "Was SOE Any Good?" 169.

${ }^{18}$ Foot, "Was SOE Any Good?" 169. 
became known as the founding document of the SOE. The document stated "that, on the Prime Minister's authority, 'a new organization shall be established forthwith to coordinate all action, by way of subversion and sabotage, against the enemy overseas." ${ }^{\prime 19}$

\section{SOE as an Aberration}

Focused on irregular warfare strategies, the SOE deviated from traditional practices of warfare. The SOE acted in the shadows of society with armed male and female agents operating under the guise of being civilians. Gary D. Solis explains in his book, The Law of Armed Conflict that "combatants fall into two categories: members of the armed forces of a party to a conflict (other than medical and religious personnel), and any others who take a direct part in hostilities. ${ }^{, 20}$ These two groups are referred to as legal and illegal combatants respectively, and their status ultimately determined their protection status - legal combatants were Prisoners of War (POW) upon capture, whereas illegal combatants had no claim to POW status. Moreover, to classify as a POW, and thus a lawful combatant, there are four requirements; "(a) that of being commanded by a person responsible for his subordinates; (b) that of having a fixed distinctive sign recognizable at a distance; (c) that of carrying arms openly; (d) that of conducting their operations in accordance with the laws and customs of war. ${ }^{.21}$ SOE agents at most met the first requirement, making them unlawful combatants and arguably outside the accepted norms of war.

Since the SOE did not follow accepted societal norms regarding warfare, a space was created for further transgressions, particularly, the use of women as agents. Captain

\footnotetext{
${ }^{19}$ Foot, SOE, 20-21.

${ }^{20}$ Gary D. Solis, The Law of Armed Conflict: International Humanitarian Law in War, $2^{\text {nd }}$ ed., (New York: Cambridge University Press, 2016), 201.

${ }^{21}$ Solis, The Law of Armed Conflict, 209.
} 
Selwyn Jepson, the recruiting officer of the French section of the SOE, primarily pushed for the inclusion of women, because he believed that "women have a greater capacity for cool and lowly courage than men, who usually want [a] mate with them. Men don't work alone their lives tend to be always in company with other men. Women are mostly on their own, a fairly logical thing." ${ }^{, 22}$ As a result, a space opened up for women to challenge traditional gender-war work hierarchies and gender power dynamics. Not only were women acting as combatants, but they were also able to own their femininity as they performed these roles.

By the D-Day invasions on June 6, 1944, the SOE had deployed thirty-nine women to Occupied France. Since female agents in the F Section needed to pass as natives - arguably more so than their male colleagues - the SOE searched for women who could blend into the French citizenry. This primarily meant that all of the women were fluent in French. This did not mean they were all French nationals, in fact it was difficult for the F Section to recruit agents of French nationality, because they were directed to the Gaullist section of the SOE (RF). Rather, these women were Polish, Romanian, British, Indian, and Irish, among other nationalities. Many of them, however, had either grown up in or spent a significant amount of time in France prior to the outbreak of war. The age of the female agents ranged from twenty to thirty-five upon recruitment.

The existence of traditional gender norms surrounding military service made it impossible for women to act as combatants without also being deemed sexually deviant

${ }^{22}$ Selwyn Jepson, interviewed by Conrad Wood, Imperial War Museum, July 3, 1986, interview 9331. 
or having their gender identity questions, attitudes which kept social norms in-check. ${ }^{23}$ Denying women status within the military subsequently played a significant role in determining the relationship between men and women. ${ }^{24}$ By being refused official combatant status - or any of the ranks associated with soldiering - women within the armed forces found themselves near the bottom of the military chain of command, similar to their social standings in peacetime. Within the SOE, however, women leveled the playing field between men and women to a certain extent. On paper, agents, regardless of sex, underwent recruitment, training and deployment together, arguably making it harder for traditional power dynamics to come into play. For instance, a male agent could not devalue the training of a female agent when he participated in the same course. Since both men and women classified as combatants, the power dynamics between men and women changed.

The SOE, however, was not impervious to social norms. The recruitment of women to act as combatants was not a popular idea, neither inside nor outside the organization. Jepson acknowledged that, "I was responsible for recruiting women for the work, in the face of a good deal of opposition from the powers to be, who said that women, under the Geneva Convention, were not allowed to take combatant duties which

\footnotetext{
${ }^{23}$ Kimberly Jensen illustrates the backlash experienced by women that participated in the military during World War I. In many cases, the women were deemed to be sexually deviant, effectively stripping them of their claims to femininity and removing them as a threat to the traditional gender hierarchy. Jensen uses the Women's Battalion of Death as an example. For further information, see Kimberly Jensen, Mobilizing Minerva: American Women in the First World War (Urbana, Chicago, and Springfield: University of Illinois Press, 2008), 60-76.

${ }^{24}$ Kimberly Jensen provides one example of the significance of military status in her book Mobilizing Minerva: American Women in the First World War. While examining the power dynamic between female nurses and men in military, particularly that women were vulnerable to the advances and demands of the men they were around, Jensen notes the overarching belief held that military rank would improve the situation. "Military rank, [Daisy] Urch insisted, would give the army nurse the 'proper protection' so that she could do her job 'and not be harassed by the petty jealousies and vagaries, peculiar to the temperament of some officers and corps men." Kimberly Jenson, Mobilizing Minerva: American Women in the First World War, (Urbana, Chicago, and Springfield: University of Illinois Press, 2008), 133.
} 
they regarded resistance work in France as being. ${ }^{, 25}$ Interestingly, none of the Geneva Conventions leading up to WWII-1864, 1906, 1929—referred to the exclusion of women from combat. The only reference to women, in any of these treaties, was in terms of their treatment as prisoners of war. For instance, Article 3 of the 1929 Geneva Convention states, "Women shall be treated with all consideration due to their sex." ${ }^{26}$

Although Winston Churchill authorized the use of women, effectively ending this debate, the division of work for SOE agents ultimately reestablished a traditional gender hierarchy. Officially, women were only trained to be wireless operators and couriers, whereas men were sent out into the field as organizers, saboteurs, and wireless operators. There were distinct advantages for women to serve as couriers over men. Historian Juliette Pattinson best illustrated such benefits when quoting an SOE report from the Netherlands that stated:

Girl couriers were used extensively, because it was a fact that women were rarely stopped at controls; and only during the period immediately before the Liberation - and even then rarely - were they searched. They were seldom picked up in mass arrests. They provided excellent cover for their movements about the country by visiting friends, carrying out shopping expeditions and later, foraging the country for food. ${ }^{27}$

Yet, characterizing courier work as "woman's work" officially discouraged women from taking up leadership roles and more dangerous work, such as the male-oriented roles of organizer and saboteur. Pattinson explained that, "A gendered division of labour was developed within the SOE with women being sent into the field only as wireless operators and couriers, thus preserving the "combat taboo," which insisted that women

\footnotetext{
${ }^{25}$ Selwyn Jepson, interviewed by Conrad Wood, Imperial War Museum, July 3, 1986, interview 9331.

${ }^{26}$ ICRC, Customary IHL Database, https://ihl-databases.icrc.org/applic/ihl/ihl.nsf/ART/305430004? OpenDocument, (accessed: January 16, 2019).

${ }^{27}$ Pattinson, Behind Enemy Lines, 136.
} 
were biologically incapable of participating in warfare. ${ }^{28}$ While Pattinson's work primarily focuses on gender in the SOE in terms of passing and the "combat taboo" in wartime France, an important aspect touched upon in the following chapters, my research adds to the scholarship by primarily focusing on the importance of war work in contradicting traditional gendered dynamics.

Despite the maintenance of social gender norms within the combatant hierarchy, the SOE war work hierarchy operated differently from traditional war work hierarchies. Conventionally, femininity is viewed as faulty, erratic, and subordinate to masculinity, perspectives that support the superiority of men. In the SOE, however, women were employed specifically because of such gender norms. The SOE capitalized on the prejudices of their enemies, knowing that social norms depicted women as ineffectual combatants. Vera Atkins, an intelligence officer at SOE Headquarters in London, explained

I've always found personally that being a woman has great advantages if you know how to play the thing right and I believe that all the girls, the women who went out, had the same feeling. They were not as suspect as men, they had very subtle minds when it came to talking their way out of situations... and they performed extremely well. ${ }^{29}$

Thus, the success of the female agents, and to an extent the success of the SOE as a whole, depended significantly on existing gender prejudices.

Since femininity was arguably more valued in the SOE than in conventional military settings, the traditional hierarchy fails to provide a full picture of power

\footnotetext{
${ }^{28}$ Pattinson, Behind Enemy Lines, 136.

${ }^{29}$ While Atkins began as a secretary in the F Section, she eventually rose the ranks to become an important officer in the SOE hierarchy. Many considered her to be as important as Maurice Buckmaster, the Head of F Section, especially when considering her personal relationship with agents. Bailey, Forgotten Voices of the Secret War, 42.
} 
dynamics within the organization. While the traditional hierarchy of war work remained intact with men at the top and women at the bottom, due to the essential nature of the women at the lower levels, they were able to reassert power from the bottom up. To better understand this seemingly paradoxical relationship — women gaining authority in their gender subordinate position — picture a Jenga ${ }^{\mathrm{TM}}$ tower, in which each level represents a different position on the traditional gender war work hierarchy. While the British government and male SOE officials dictated the actions of the SOE from the top, because the structural integrity depended on the lower pieces - the female couriers and $\mathrm{W} / \mathrm{T}$ operators - women in the SOE were integral to the success of the organization. If they were removed, like pieces from the tower, the ability for the circuit and the SOE to function properly was compromised. This supporting dynamic altered the traditional flow of power and gave lower ranking female agents greater authority, as will be seen in the following chapters.

Additionally, because femininity was particularly valuable in the field, female agents further disrupted gender dynamics. Women were able to own their femininity, rather than hide or change it, in war. The legitimization of this ownership by SOE officials - even if flawed — confirmed the significance of female participation and the ability for women to impact the war effort from the bottom.

Ultimately, these women were exceptional. Not everyone could follow in their foot-steps, taking on such extreme levels of danger, and oftentimes going beyond expectations. Recognizing that they were women, who owned their gender, and used it to their advantage, is crucial for understanding their greater impact on the SOE and the relationship between women and war. 


\section{CHAPTER 2: RECRUITMENT, TRAINING AND PERCEPTIONS OF CHARACTER}

"'If you're caught by the gestapo there's a good chance you would be tortured and shot." "' This warning was issued to potential agents during the interview portion of the recruitment process. Although SOE HQ released little information regarding its missions, the danger involved was clearly stated in interviews. Thus, women faced the real consequences by serving as illegal-combatants.

Nonetheless, though women earned the status of combatant in the SOE, the recruitment and training of female agents to a certain extent reestablished traditional gender norms. Women were evaluated in terms of perceived stereotypical feminine behaviors, and the accentuation of gendered terms often resulted in the negative evaluations of performance. This chapter will primarily focus on the recruitment and training of female agents in the SOE. Traditional gender power dynamics, including the push back against the inclusion of female combatants, illustrates the ways in which the SOE both co-opted traditional societal norms and challenged them. On one hand the organization attempted to stymy the authority of female agents by maintaining both actual and rhetorical female inferiority. The subordination of women in the SOE also meant that men — particularly in training — had to compete on a similar level to preserve their claim to masculinity. It also feasibly helped quell arguments against the inclusion of women in war. Moreover, the SOE understood of the tactical advantage of manipulating traditional norms regarding femininity. On the other hand, the employment of women this non-traditional role provided the opportunity for female agents to problematize popular

\footnotetext{
${ }^{1}$ Pattinson, Behind Enemy Lines, 27.
} 
perceptions regarding the relationship between women and war. The requirements of recruitment and training undergone by the women illustrates their competency in irregular warfare and their unique skill sets, which oftentimes set them apart from their male counterparts. As will be seen throughout this chapter, F Section female recruits' fluency in French, expertise in French culture and mannerism, and adaptability to a given scenario all contributed to their acceptance and accomplishments in the SOE. ${ }^{2}$ Adaptability, in particular, was an important skill for female agents as the predictability of war time affairs was small. Being able to change actions at a minute's notice, take on a different persona, or, even, become a different person altogether, often made the difference between success and failure for an agent whether male or female.

The experience of female recruits illustrates how SOE recruitment and training officers relied on gender norms to determine the supposed success or failure of an individual. Pattinson notes the mixed opinions of agents regarding the equality of treatment during these stages of the wartime experience. My analysis of the official documentation highlights how perceptions of femininity were used to either uphold or oppose certain agents.

\section{Recruitment}

Not everyone could be an agent in the SOE. Undercover work, which was the majority of work undertaken by agents—especially women who acted as couriers and were subsequently the most visible individuals in a circuit—required certain skills, behaviors and traits. Passing as a native in an occupied territory while also assisting

\footnotetext{
${ }^{2}$ For further information regarding the linguistic, appearance and other qualities evaluated during recruitment, see Juliette Pattinson, “'To pass as a native': recruiting for operations in France," in Behind Enemy Lines: Gender, Passing and the Special Operations Executive in the Second World War, (Manchester: Manchester University Press, 2007), 25-50.
} 
subversive missions, was the end goal. That said, while some of the skills required could be taught, others needed to be part of one's upbringing or pre-existing civilian identity.

The secretive nature of the organization ultimately hindered the ability for the SOE to recruit agents. According to MRD Foot, the SOE relied primarily on word of mouth, otherwise referred to as the "old boy network." Foot asked, "how else could [the SOE] recruit?"3 While propaganda greatly impacted the enlistment of various military branches - patriotic posters exclaiming "Uncle Sam I want YOU for U.S. Army" and "We beat 'em before. We'll beat 'em again" uplifting the national spirit and encouraging enlistment in the US and Britain - the SOE could not rely on such outwardly nationalistic calls to service. Rather, as Foot explained, "If you'd been to public school with somebody, you knew whether he was any good...Women could come in equally as people could have sisters, cousins, etc, who they would know and invite them to join [the SOE]. .4

Overall, the recruitment process included a series of interviews of perspective agents, people oftentimes showing up to the interview with little knowledge of purpose of their visit. For instance, Yvonne Cormeau was in the Women's Auxiliary Air Force (WAAF), and following her husband's death, she "received a telex from London asking that [she] should come down to town as soon as possible to see a certain Captain Selwyn Jepson." Cormeau's language capabilities in German, Spanish and French had become known to the SOE, leading to this invitation. Odette Sansom was recruited through an advertisement that she "'saw in the newspaper and heard on the radio that if people had

\footnotetext{
${ }^{3}$ Pattinson, Behind Enemy Lines, 28.

${ }^{4}$ Pattinson, Behind Enemy Lines, 28.

${ }^{5}$ Bailey, Forgotten Voices of the Secret War, 40.
} 
photographs of a certain part of the coast of France would they send them to an address in London." " A few weeks later, Sansom received a letter asking if she would journey to London for an interview, which she originally thought was simply about returning her pictures. ${ }^{7}$ After the first interview, she was asked back and the topic of subversive work was finally broached. The interviewer told her, "'We train people here... and we send them to the country of their origin, or if they speak a foreign language very well we send them to that country, where they can use it and be useful to the war effort.",8

The directive of the SOE was not disclosed in the interview process - only that recruits would return to occupied Europe, or other territories, but interviewers were assessing an array of characteristics that signaled whether a person would be a good agent - taking into account both tangible, traits visible to the outside world, and intangible traits. Sex/gender, appearance, language, and mannerisms constituted an individual's tangible identity. Since passing among the native population was a significant element of the work undertaken by agents, particularly the women, these traits were an important aspect for interviewers to consider. ${ }^{9}$

Intangible qualities of an agent's character, such as motive, were also important for recruiters to note during the interview process. Motives could highlight the

\footnotetext{
${ }^{6}$ Odette Marie Céline Sansom, interviewed by Conrad Wood, Imperial War Museum, October 31, 1986, interview 9478.

${ }^{7}$ Odette Marie Céline Sansom, interviewed by Conrad Wood, Imperial War Museum, October 31, 1986, interview 9478 .

${ }^{8}$ Odette Marie Céline Sansom, interviewed by Conrad Wood, Imperial War Museum, October 31, 1986, interview 9478.

${ }^{9}$ Juliette Pattison focuses on many of these qualities in her book Behind Enemy Lines, specifically looking at "French nationality or alternatively an ability to speak French 'like a native,' a typically 'French appearance' and various other 'necessary qualities." The last category referred to more abstract aspects of an agent's character, such as motive for joining the SOE, which will be primarily discussed in this section. Pattinson, Behind Enemy Lines, 29; Juliette Pattinson, "'To pass as a native': recruiting for operations in France," in Behind Enemy Lines: Gender, Passing and the Special Operations Executive in the Second World War, (Manchester: Manchester University Press, 2007), 25-50.
} 
determination of a prospective agent when working in the field, as well as help underscore where loyalties lay. Recruiters paid little attention to the pre-recruitment work of women, perhaps due to expectations that women's work prior to the SOE was insignificant. That said, the forty female agents recruited had real life experiences that potentially impacted their desirability as agents, in particular those already serving in the WAAF or the First Aid Nursing Yeomanry (FANY), or the women participating in the various resistance groups in Europe.

\section{WAAFs, FANYs, and Military Professionals}

The First Aid Nursing Yeomanry was founded in 1907 by Captain Edward Baker, who envisioned "courageous horsewomen in scarlet uniform galloping side-saddle onto the battlefield to tend to the wounded and transport them to military dressing stations." The original conception of this auxiliary force contradicted traditional conceptions of women in war, as noted by Janet Lee in her book War Girls: The First Aid Nursing Yeomanry in the First World War. Instead of remaining on the homefront, in the private sphere, the women were "to be present on the battlefield" and acquire technical skills that "deviated from the traditional expectations of the fairer sex (and certainly from standard nursing duties). ${ }^{, 11}$ Even though FANYs were nurses, conforming to the hegemonic feminine, the conscious original intention of these women to move onto the battlefield challenged traditional norms in war-protecting women from the horrors of war. With this legacy, FANY became an appropriate place for the SOE to recruit.

\footnotetext{
${ }^{10}$ Janet Lee, War girls: The First Aid Nursing Yeomanry in the First World War (Manchester and New York: Manchester University Press, 2005), 32.

${ }^{11}$ Lee, War girls, 35.
} 
In June 1940, members of FANY were incorporated to the SOE. ${ }^{12}$ According to Lee, "several thousand FANY were employed by the British Special Operations Executive...working 'in ciphers and signals, as agents-conducting officers, [and] administering the Special Training Schools." ${ }^{\prime 13}$ In the beginning, these women "were prepared to undertake any duties that might be useful, such as housekeeping, driving, cooking, orderly work and packing: and, in fact, the first F.A.N.Y. attached to the S.O.E. were employed as housekeepers and drivers." ${ }^{\prime 14}$ The early relationship between the FANYs and the SOE, therefore, reinforced the limited participation of women in warfare. Instead of allowing women to become combatants, the SOE utilized women in traditional female, non-combatant work. It was only in 1941 that the SOE began considering the use of FANYs in non-traditional roles; "In November 1941, Lieut. BINGHAM was asked if she though the F.A.N.Y. would train as Wireless Operators, since W/T [wireless transmission] personnel were being dropped into Europe, and it was necessary that women should be trained to receive their messages."15

This transition from "women's work" to technical jobs that were previously dominated by male employees, highlights the slow shift within the two organizations that eventually sanctioned the participation of FANYs in further untraditional jobs. A year later, in 1942, "An agreement was entered into with the War Office and Ministry of Labour to enable F.A.N.Y. to be recruited into S.O.E. and paid." ${ }^{16}$ Moreover, "In April 1942, it was decided to recruit women for the field" through FANY.${ }^{17}$ In January 1942 ,

\footnotetext{
${ }^{12}$ The National Archives HS 7/7.

${ }^{13}$ Lee, War girls, 253.

${ }^{14}$ The National Archives HS 7/7. For further information see Janet Lee, War Girls: The First Aid Nursing Yeomanry in the First World War, (Manchester and New York: Manchester University Press, 2005).

${ }^{15}$ The National Archives HS 7/7.

${ }^{16}$ The National Archives HS 7/7.

${ }^{17}$ The National Archives HS 7/7.
} 
female recruits outside of the FANY, were funneled into the SOE through FANY. This was a strategic move on the part of the SOE because officials hoped that nurses' military status, although inferior to the male-soldier equivalent, would provide some protection for their female agents if caught by the enemy.$^{18}$ Thus, whether they were previously part of the FANY or not, female SOE agents "wore [the] F.A.N.Y. uniform during their training and on their return to the U.K." instilling in them "a background, morale, and status." 19

Although the FANY became the official link between traditional military organizations and the SOE, women employed in other branches found themselves funneled into the organization. Noor Inayat Khan, for instance, was in the Women's Auxiliary Air Force (WAAF) prior to her recommendation to the SOE. The WAAF was established in June 1939 and the women acted as "cooks, clerks, orderlies, equipment assistants and motor drivers (fabric workers being added for companies attached to balloon squadrons). ${ }^{20}$ In a letter written on February 12, 1943, a superior-although it is not clear who authored the document as they only signed "Capt."—endorsed Khan's character, stating;

I have known this applicant socially for a considerable period and I have no hesitation at all in saying that she is, in my opinion, fully qualified to be a member of the F.A.N.Y. She has never belonged to or had any connection with an organisation of a subversive character and is morally of good name. This lady will do excellent work in connection with the special employment in which it is proposed that she should serve. ${ }^{21}$

\footnotetext{
${ }^{18}$ Under the Law of Armed Conflict, illegal combatants receive little to no protections under international law. Rather one must classify as a legal combatant, which these female agents did not qualify as, to access the rights of a Prisoner of War (POW). This will have unfortunate consequences in the wartime experiences of SOE female agents, as will be explored in later chapters.

${ }^{19}$ The National Archives HS 7/7.

${ }^{20}$ Jeremy A. Crang, "The revival of the British women's auxiliary services in the late nineteen-thirties," Historical Research 83, no. 220 (May2010): 353, DOI: 10.1111/j.1468-2281.2008.00478.x

${ }^{21}$ The National Archives HS 9/836/5.
} 
As many other women, Khan "felt that she has come to a dead end as a WAAF., and was longing to do something more active in the prosecution of the war, something which would make more call on her capabilities and perhaps, demand more sacrifice" as noted in her personnel file. ${ }^{22}$ This acted as a core motive for Khan, as well as other agents in the SOE, especially women who were limited in their ability to participated in the war effort. Occupational background and motives reveal the types of women that were eventually employed by the SOE.

The WAAF and FANY were not the only official military organizations that the SOE recruited women from, in fact the SOE partnered with the US Office of Strategic Services (OSS) when they included Virginia Hall in the SOE organization. Hall was a female agent for the OSS who acted as liaison between the two organizations. Hall began operating in Vichy France as early as April 1941, prior to official US entry into the war, and was subsequently recommended to the SOE. A letter explaining that "Robertson, correspondent to P.M. in London, confirms that he has seen Miss Virginia Hall and is quite agreeable to her going to Unoccupied France... We hope to use Miss Virginia Hall...for liaison and intelligence work in Vichy France with newspaper cover...Miss Hall...is known to us as a reputable person..."23

Khan and Hall are just two examples of women who were employed by official military organizations prior to their recruitment to the F Section. As such, these women already had first-hand experience with the more mundane aspects of military organizations, and its gendered structure.

\footnotetext{
${ }^{22}$ The National Archives HS 9/836/5.

23 The National Archives HS 9/647/4.
} 


\section{French Resistance Members}

Nancy Wake's recommendation likely came from someone who knew her from her participation in "Underground work" in France during 1940, her recommendation letter read, "I have known the applicant in a professional capacity long enough to feel sure that she is suitable for confidential work, and have no hesitation in recommending her. This lady has qualifications which render her valuable for special operation duties.. ${ }^{24}$ SOE historian Roderick Bailey elaborated on her connection to the French resistance, stating that "In 1940, with France defeated, Wake and her husband began assisting the clandestine escape to neutral Spain of fugitive allied evaders and escapers. ${ }^{25}$

Wake was not the only female recruit with previous experience in subversive warfare. Madeleine Damerment was also seemingly recommended by a contact from the French resistance as a memo was sent to the SOE asserting that, "[Damerment] worked for us for a short time during 1940-1941 and had to be sent out of France as we feared she was being sought by the Gestapo... She did very good work for us and we have no objection to her being employed by S.O.E." ${ }^{26}$ Dated October 25, 1943, this memo was not signed, however, the reference to "we" in the document provides the necessary context to assume that it was sent from someone with the resistance networks in France. Even though Damerment fled from France, posing questions regarding her success in resistance work, it is important to understand that success in this context differed from the success in a traditional military or during peacetime. This idea will be explored in

\footnotetext{
${ }^{24}$ The National Archives HS 9/1545.

${ }^{25}$ Roderick Bailey, "Wake, Nancy Grace Augusta," Oxford Dictionary of National Biography, 08 January 2015, https://doi.org/10.1093/ref:odnb/104083.

${ }^{26}$ The National Archives HS 9/1654.
} 
greater depth in following chapter, but Damerment's experience working in the French Resistance, regardless of her tenure, was nonetheless experience.

SOE headquarter personnel reaffirmed Damerment's past association, explaining that "From soon after the collapse of FRANCE, the family DAMERMENT became active members of an organisation whose main object was to assist French prisoners of war... she found herself to be taking a very keen interest in this sort of work and in the wellfare $[$ sic $]$ of the French prisoners of war and their escape. ${ }^{27}$ Moreover, Damerment helped British prisoners of war in northern France escape. ${ }^{28}$ As such, Damerment's work was recognized as "very risky as she was constantly out in the streets with British airmen and prisoners of war and had [she] been caught in this sort of thing, [the] death penalty would have been unavoidable." ${ }^{29}$ After her story was confirmed and the security risk was deemed limited, Damerment went on to training. ${ }^{30}$

Andrée Borrel had a similar background to Damerment. Living in France and working as a nurse following the German invasion in May 1940, Borrel became involved with resistance work in 1941. After meeting a British Airman, known in records as Lieutenant Dufour, a member in the French resistance in contact with the SOE, Borrel left her work as a nurse “in order to work for [Dufour's] Organisation which facilitated the escape of British Airmen shot down over France and British escaped prisoners-ofWar." ${ }^{31}$ After fleeing France for security measures, like Damerment, Borrel arrived in England and looked for ways to contribute to the war effort. In May 1942, Borrel

\footnotetext{
27 The National Archives HS 9/1654.

${ }^{28}$ The National Archives HS 9/1654.

${ }^{29}$ The National Archives HS 9/1654.

${ }^{30}$ The National Archives HS 9/1654.

31 The National Archives HS 9/183.
} 
interviewed with the SOE stating that "since arriving in LONDON, she attempted to join the CORPS FEMININ of the Free French movement. ${ }^{, 32}$ According to a memo written that day, she did not join because the Free French movement "made it a condition that she should give them all the intelligence concerning the organisation for which she was working in France. This she [refused] to do and apparently they [refused] to employ her unless she [did]."33

Information regarding occupied territories was particularly valuable to organizations such as the SOE, and as a result Borrel was recruited by the SOE. The author of the May 1942 memo asserting "I think that she would make an excellent addition to our own CORPS FEMININ..."

Christine Granville was another example of the usefulness of women with resistance experience. Granville was an interesting case because she had been in contact with the SOE since its conception and operated in Eastern Europe as well as Cairo before being deployed to France in 1944. As such, her extensive experience with both undercover work and resistance groups made her an incredibly attractive recruit for the SOE. One report stating, that "It is assumed that CHRISTINE is the only trained W/T operator at our disposal who has any knowledge of Hungary, has the requisite personal qualities, would stand at least a chance of survival and is willing to be infiltrated." ${ }^{, 35}$ As one of the only women with such a repertoire it is understandable why she was employed by the SOE for the entire war.

\footnotetext{
32 The National Archives HS 9/183.

33 The National Archives HS 9/183.

34 The National Archives HS 9/183.

35 The National Archives HS 9/612.
} 
The qualities that the SOE looked for in female recruits inadvertently revealed a range of extraordinary accomplishments before joining to SOE. Whether finding a way to escape from occupied territory—which was not an easy feat—or aiding in the resistance networks prior to the SOE, these women had already set themselves apart.

Not everyone could be an agent in the SOE; not everyone had the drive to voluntarily go above and beyond their required duty. All of the women mentioned in this section, along with the other women recruited for the F Section, did not need to volunteer for such a dangerous wartime occupation. Women such as Khan could have remained with the WAAF, or those that were part of the resistance movements could have decided to live out the rest of the war in England. In both situations, the women had already arguably filled their civic duty to the war effort in an outwardly dangerous manner. Their dedication to the war effort was not found in everyone, and became important aspects to consider when recruiting.

These women were probably more qualified than some of the men who joined traditional militaries during World War II. In fact, FANY records recount the highly selective process of recruitment of women from such organizations, which "resulted in a high standard of intelligence, initiative, and stability of character." ${ }^{\prime 36}$ The division between male combatants in a traditional military and these women was in name rather than in attributes and experiences, especially considering their formal training.

\section{Training}

While the recruitment process primarily looked at the inherent qualities of an agent, training began to mold female recruits into agents. Although the time spent in

\footnotetext{
${ }^{36}$ The National Archives HS 7/7.
} 
training varied, particularly because the demand for the deployment of agents sometimes cut the length of training short, agents generally went through three training schools; preliminary school, paramilitary school, and finishing school. The other exception to this course of training was the time in which an agent was recruited, because these three schools were only solidified after 1942. As part of the general information distributed to agents in training, based on a memorandum in Pearl Witherington's personnel file, women who parachuted into France first "had to undergo an arduous course of training...in fieldcraft, map reading and particularly in security, as not only their own safety but that of their whole group." 37

The purpose for these three stages was to not only provide specialized information, but also to help eliminate recruits deemed unsuitable for work in the SOE. ${ }^{38}$ Furthermore, the various levels acted as a security measure. Agents did not officially know what the SOE did or what their role would be in this organization, beyond that they would be sent to France, until they finished training. Since details were distributed on a need-to-know basis, agents learned more information as they progressed through training, and some were able to guess the type of work they would be doing.

Ironically, rather than reaffirming female agents' combatant status, this period of training invoked traditional gender norms. While agents were taught basic skills and trained for their SOE related job—-such as wireless transmission or sabotage operationsthe evaluation of their behavior during and reactions to training were dependent on the situation. Simulations arguably provided greater insight into an agent's potential success

\footnotetext{
${ }^{37}$ The National Archives HS 9/356.

${ }^{38}$ Candidates could be removed at any point and for many reasons. After failing, they would be relocated to a holding area to be observed until they were no longer considered a security risk.
} 
for the field than the individual skills taught—it was the ability to apply the training to real life scenarios that mattered. This was especially true considering training lasted days or weeks, rather than months or years. ${ }^{39}$ As a result, the training schools doubled as a prolonged evaluation, building upon initial interviews. Even though some reports were reserved for an assessment of technical skills—-like weapons training and codes—a majority of these comments emphasized the attitude and actions of agents. Focusing on an agent's temperament, persistence, and ability to work with others, these documents attempt to determine the potential success of an agent.

While there were certain traits that hindered the chances of becoming an agent, particularly actions that drew unnecessary attention to an individual, behaviors stereotypically associated with femininity were also assessed negatively. Being overly emotional, erratic, and vain, for instance, resulted in SOE trainers questioning the capabilities of an individual and could lead to removal from training, regardless of the stage of training they were completing. Nancy Wake was temporarily dismissed due to reports of drunkenness, but was later reinstated when an official noted in a report "I can easily imagine that her almost abnormal cheerfulness could be easily mistaken for drunkeness [sic]. ${ }^{, 40}$ The incorrect interpretation of a female recruit's character, as seen in Wake's case, demonstrates the need to question the accuracy of comments about female agents. Were the critiques warranted or simply commentary on the agent's gender? Moreover, it is important to explore the moments in which gendered expectations were

\footnotetext{
${ }^{39}$ Due to the high demand of agents, whether for new missions, an expansion of territory, or as replacements to lost agents, training could only last so long. In some cases, training was cut short in favor of a faster deployment. As such, the lived experiences prior to recruitment were important because they added to an agent's repertoire of skills.

${ }^{40}$ The National Archives HS 9/1545.
} 
applied in evaluations. Women were specifically employed by the SOE because of their gender, therefore officers at training schools undoubtedly viewed female recruits in accordance to certain assumptions. This, unsurprisingly, had both positive and negative outcomes in the evaluation of agents.

While not all comments were negative, an evaluation of language is important because these reports impacted the future careers of these agents. Plus, the reports potentially impacted the perceived worth of an agent. Although hindsight is twentytwenty, in many cases the women who became great agents, such as Pearl Witherington and Nancy Wake, were given poor training reviews and viewed as only suited for subordinate roles.

\section{Actions in Relationship to Work}

The aptitude of an agent in relationship to both the overall and the work-specific training was a considerable concern to SOE officers, who continually evaluated the strengths and weakness of each agent. The ability to properly shoot a gun, for example, likely determined the capability for an agent to protect themselves. These physical aspects of the agents' training were arguably the most direct evaluation of an individual's success in the field.

As women were employed primarily as wireless operators and couriers, the training at specialty schools was crucial for determining their wartime occupation. For instance, Yolande Beekman was praised for her work in mastering wireless transmission; "She shows any amount of determination in mastering the intricacies of W/T and gives 
the impression that although she expects to learn slowly and with pains, it never occurs to her that she will not get there in the end."41

From the beginning of training, Marguerite Knight was flagged as a potentially successful courier. Citing her civilian record, which detailed her as "efficient and adaptable," the initial training report stated, "She would make a good courier and although her temperament is perhaps a little too energetic and active to make her an ideal W/T operator, she will no doubt train well in this work and do it efficiently and well."42 Furthermore, in the final training reports, officers reaffirmed her capabilities as a courier after a simulation, explaining that "This young lady did a very good scheme and seems well suited to act as a courier. Indeed she has the intelligence and initiative to take on even more responsible work." ${ }^{43}$ Knight was one of the few women to receive such a positive review, rarely was a woman recommended to take on more work during training.

Nancy Wake's experience during training was more tumultuous than the average agents due to her temporary suspension from the SOE. Rising to the occasion, however, one of Wake's instructors noted in her file that she was "A very keen, hard-working student who has a lot of common sense. She is a determined type, who should prove to be extremely useful in the field, as a lieutenant or W.T. Operater [sic]." ${ }^{44}$ Following her training, Wake was sent into France to act as an assistant to a circuit organizer.

Noor Khan, one of the more well-known SOE agents, received mixed reports regarding the technical side of her training. During a 96-hour scheme, a final simulation meant to see how well agents applied training, Khan was both praised and reprimanded

\footnotetext{
${ }^{41}$ The National Archives HS 9/114/2.

${ }^{42}$ The National Archives HS 9/849/7.

${ }^{43}$ The National Archives HS 9/849/7.

${ }^{44}$ The National Archives HS 9/1545.
} 
for her actions. Khan impressed her instructors with the security precautions she took during the simulation, following protocol by taking "precautions against search and surveillance. She carried no incriminating papers with her as she memorised her orders before leaving here. ${ }^{45}$ That said, during a mock police interrogation, the report stated that "She made several stupid mistakes during this interrogation which could easily have been avoided by a little forethought. She always volunteers far too much information when being questioned." ${ }^{46}$

Despite her failings during this training exercise, Khan was ultimately successful in the perspective of her supervisors; "This student has obviously worked very hard and [shown] interest in the exercise, but, however, she must learn to be more discreet. Apart from the police interrogation, I consider this quite a good scheme. ${ }^{47}$ This comment is particularly important to consider because of its emphasis on persistence and determination. This points out the fact that in field not everything can be minutely controlled and perfected, thus instead of demanding an unreasonable level of perfection, determination and dedication were of value.

Not all reports of this categorization, however, were as positive or encouraging. Instead, many highlighted the shortcomings of the technical training of female agents. Eileen Nearne received a particularly scathing account during finishing school. Although not as specific as the previous reports, this document asserted that "She is not very intelligent or practical and is lacking in shrewdness and cunning. She has a bad memory, is inaccurate and scatter-brained. She seems keen but her work was handicapped by lack

\footnotetext{
${ }^{45}$ The National Archives HS 9/836/5.

${ }^{46}$ The National Archives HS 9/836/5.

${ }^{47}$ The National Archives HS 9/836/5.
} 
of the power of concentrate. ${ }^{48}$ E. Nearne's flaws, if accurate, would hamper survival in the field. That said, this report is devoid of any context regarding both the situations in which she erred and her state of being. Considering this was one of the final parts of training, E. Nearne was potentially tired or overwhelmed. Furthermore, the language of this comment was overly negative. The author continually reasserted her apparent unintelligence and using "scatter-brained," which has a very negative connotation, rather than absentminded, develop the gendered aspect of this language.

\section{Perception of Character}

When examining the training reports of female agents there was a greater emphasis on their character than their proficiency of technical skills. While some women were commended for their behavior and temperament, in many instances commanding officers wrote extremely critical comments. It is important to point out that each file contains comments from different authors, whether because the evaluations occurred at different stages of training with different superiors or because there were different instructors for certain technical aspects of a school.

This fact only contributes to the uncertainty of the accuracy of reports. Since agents only spent a limited amount of time at each school — at most a few weeks - it is improbable that their core personality changed significantly. Furthermore, in the cases that women were only at the school for a handful of days or a week, how precise could observers be regarding an agent's personality? This increases the likelihood that officials misunderstood the complexities of some agents' disposition. The training reports of Lise de Baissac, Andrée Borrel, Madeline Damerment, Violet Szabo, and Anne-Marie Comert

\footnotetext{
${ }^{48}$ The National Archives HS 9/1089/2.
} 
illustrate the degrees of appraisal for character traits. These four files provide examples that were incredibly positive at one end of the spectrum, as in the case of Baissac, to largely dismissive on the other end, as seen in Comert's file.

Lise de Baissac's reports were overwhelmingly favorable regarding her as an "Intelligent, extremely conscientious, reliable and sound in every way...capacity to sum up a situation, make a decision and stick to it without becoming flustered... a very high degree of self confidence..." ${ }^{49}$ One source going as far as stating that, "She was very much ahead of her fellow-students and, had she been with others as mentally mature as herself, she would have shown herself even more capable. ${ }^{.50}$ Considering female and male agents trained together, this comment is incredibly telling of both the SOE's inclusion of women and the perceived value of Baissac. As will be seen later, Baissac became a successful agent in the field, making such statements warranted.

While Baissac provides an example of an overarching positive review of her time during training, the following agents were deemed to possess some of but not all the qualities that the SOE valued in agents: intelligence, assertiveness, the ability to work well with others, and emotional maturity.

Andrée Borrel's report reaffirms many of these characteristics, although she fails to showcase all of them successfully in comparison to Baissac. In a commandant's report during paramilitary training, Borrel was described as "Of sound intelligence, if lacking somewhat in imagination. She has little organising ability and will do her best work under definite instructions. She is thoroughly tough and self-reliant with no nerves. Has plenty of common sense and is well able to look after herself in any circumstances and

\footnotetext{
${ }^{49}$ The National Archives HS 9/77/1.

${ }^{50}$ The National Archives HS 9/77/1.
} 
she is absolutely reliable." ${ }^{51}$ The difference between Borrel and Baissac's portrayal is important because it begins to highlight the potential effects of these reports. While Baissac clearly ranks above both the men and the women in her group, because Borrel apparently lacks certain traits, particularly organization, there was no doubt in the minds of SOE officers that she needed to be a subordinate, not leadership, position. Even though this seems to be an accurate depiction of Borrel, mentioning both her strengths and weaknesses, this example nevertheless demonstrates how valued characteristics ultimately shaped the chain-of-command.

Violet Szabo's training report provides the best example of a middle ground between the two ends of the spectrum for character approval during training. An instructor admitted that her

Character [was] difficult to describe:- Pleasant personality, sociable, likeable, painstaking, anxious to please, keen, mature for her age in certain ways but in others very childish. She is very anxious to carry on with the training but I am afraid it is not with the idea of improving her knowledge but simply because she enjoys the course, the spirit of competition, the novelty of the thing, and being very fit... ${ }^{52}$

She was praised for qualities that follow traditional gender norms, specifically her pleasant disposition and her people-pleasing tendencies, but is rebuked for her ambition.

Interestingly, Damerment, who had first-hand experience with the French resistance, was flagged as troublesome in her training report. In one instance, a commandant reported that "I have not a great deal of faith in this student. Although she has a good brain, she is too temperamental and not sufficiently impersonal for a firstclass student. She has, however, a good sense of humour and a certain amount of charm

\footnotetext{
${ }^{51}$ The National Archives HS 9/183.

52 The National Archives HS 9/1435.
} 
and intelligence." ${ }^{53}$ Damerment's report shows a move farther away from the unadulterated praise received by Baissac. Moreover, gendered language appears as Damerment was appreciated and criticized for some more traditionally feminine traitsher charm and her temperament respectively.

Furthermore, while attending the paramilitary school, Damerment's advisor noted that "she did not always work very hard. Her character is strong, but she is self-centred [sic], rather irresponsible and sometimes impatient and turbulent...personal relationships play a considerable part in her life... she can be pleasant when she wants to be, but she is also inclined to be malicious and sulks when she does not get her own way..." 54 Ultimately, the report ends with the recommendation that "This student should make a satisfactory subordinate under a strong leader, but she would need careful handling." ${ }^{55}$ These comments, again even if true, illustrate how negative perceptions of agents resulted in their underestimation before being deployed. As will be seen in the following chapter, many of the women who were devalued during training, and placed in subordinate positions due to perceived flaws, often went above and beyond the expectations set for them during training.

Anne-Marie Comert was one of the more troublesome female agents in the SOE. Although referred to as "A keen, very intelligent girl with a realistic practical sense. Ample courage, determination and a sense of humor," the SOE deemed her more problematic than useful. ${ }^{56}$ This is seen in the following characterizations, which arguably illustrate the ways in which gendered language was applied. One report stating that

\footnotetext{
${ }^{53}$ The National Archives HS 9/1654.

${ }^{54}$ The National Archives HS 9/1654.

${ }^{55}$ The National Archives HS 9/1654.

${ }^{56}$ The National Archives HS 9/339/2.
} 
"Whilst I appreciate Walters to be an extremely courageous young woman, nevertheless I feel bound to draw attention to her exhibitionist tendencies, which are very bad from a security standpoint." ${ }^{57}$ Furthermore, her instructors recognized her potential asserting that "She has marked latent capabilities but is at present immature, inexperienced and not sufficiently in control of herself for subversive work. With maturity she should prove a girl of exceptional qualities." $" 58$ Yet, by characterizing Comert as "a girl" rather than the twenty-year old woman she was at the time of her recruitment, the SOE underestimated and diminished her capabilities through gendered language.

Even though the problems pointed out in these examples might be valid, they also illustrate how women were held to a certain gender expectations, standards that could have negative consequences by unnecessarily devaluing an agent's potential.

\section{Gender Expectations}

Contradictions soon crept into the SOE's evaluation of female agents. Comert was clearly a flawed agent, whether because of her innate personality or her youth. She was also faulted for flaunting her sexuality. For instance, in training she was criticized for "not [hesitating]...to make use of her physical attractiveness in gaining influence over men." 59 Femininity, however, was one of the reasons that women were employed in the first place and ended up being a useful tool in the field for some agents. For instance, Sonya Butt recalled that a fellow male recruit " made me lead all the time. I'd be the first of the group of five when we were going on a mission, or doing whatever...His theory

\footnotetext{
${ }^{57}$ The National Archives HS 9/339/2.

58 The National Archives HS 9/339/2.

59 The National Archives HS 9/339/2.
} 
was if I did it, they'd have to even if they found it tough. They'd have to keep up with a girl. ",60

Whereas Comert was viewed as overly-sexual, other agents were denounced as not attractive enough. Yolande Beekman was deemed to be "feminine enough." ${ }^{61}$ Noted in the initial interviews of Beekman, this comment confirms the importance of femininity. Yet, the undertone of the statement was also negative, as if she just barely passed the threshold of femininity. Such comments demonstrate the inherent contradictions that existed in expectations for female agents. While on one hand they were praised for possessing traits traditionally associated with the hegemonic masculine norm—such as maturity, intelligence, and confidence — on the other hand, the women were similarly chastised when they did not display enough feminine qualities. ${ }^{62}$

As a result, if the women did not strike a happy medium between classically feminine and masculine traits, they were unequivocally diminished in their perceived usefulness as agents. Eileen Nearne, for instance, was depicted as “very 'feminine' and immature," and subsequently viewed as "[lacking] all experience of the world and would probably be easily influenced by others." ${ }^{\prime 63}$ This presents an image of a damsel in distress, incapable of fending for herself, which does not align with the fact that E. Nearne escaped from occupied territory with her sister Jacqueline.

E. Nearne was also faulted for the little experience she has with irregular warfare; "It is doubtful whether this student is suitable for employment in any capacity on account

\footnotetext{
${ }^{60}$ Pattinson, Behind Enemy Lines, 64.

${ }^{61}$ The National Archives HS 9/114/2.

${ }^{62}$ For further information see The Routledge History of Gender, War, and the U.S. Military, ed. by Kara Dixon Vuic (London and New York: Routledge, 2018).

${ }^{63}$ The National Archives HS 9/1089/2.
} 
of her lack of experience." ${ }^{64}$ Of all of the inaccurate expectations for female agents, this was potentially one of the worst for two reasons. First, it assumes that these women were significant participants in the pre-war public sphere. While some did have occupational experiences outside of wartime, they were mainly dressmakers, typists, or secretaries. Second few agents recruited, whether male or female, had experience in irregular warfare. Considering this was one of the first times that women were authorized to participate in combat, this was an unrealistic expectation of the SOE.

The result of many of these inaccuracies was the devaluing of female agents, which impacted their initial occupation when deployed to occupied France. In many cases, the women were classified as insufficiently qualified for field work and assigned to "handler," meaning a male superior. In Beekman's report, she was deemed as "not a sufficiently strong personality to be a leader but should make an excellent subordinate or W/T operator." ${ }^{65}$ Witherington, regardless of all of the praiseworthy comments on her training reports, was seen as not having "the personality to act as a leader, nor is she temperamentally suited to work alone. She would be best employed as a subordinate under a strong leader in whom she had confidence." ${ }^{\prime 66}$ Yet, in 1944 Witherington became a successful organizer, illustrating the potential misjudgments made by evaluators during training.

Interestingly, although male agents were not praised for any sign of emotional or psychological instability, Francis Nearne's - the brother of Eileen and Jacqueline Nearne - poor temperament was excused on accounts of his help with resistance work in

\footnotetext{
${ }^{64}$ The National Archives HS 9/1089/2.

${ }^{65}$ The National Archives HS 9/114/2.

${ }^{66}$ The National Archives HS 9/356.
} 
France prior to being recruited to the SOE. Of the remarks made in his training reports, one supervisor asserted that F. Nearne was "A man of exceptionally low intelligence. Rescued rather than recruited in the field. He gives no history of any sustained work and his performance here fully confirms this impression. He shows many signs of an unstable personality and should on no account be sent into the field. ${ }^{.67}$ Nonetheless, he continued on to specialized training because of his sisters' successes. Even when Lt. Gordon at a specialty school noted his nervousness, he nonetheless gave F. Nearne the benefit of the doubt. Gordon reported that "he tried very hard and to everybody's satisfaction...He has the inestimable advantage of speaking perfect French and has done a little work in France. ${ }^{, 68}$ Eventually, however, F. Nearne was dismissed from training.

His removal from SOE training did not mark the end of his relationship with the organization. There are several memorandums in his personnel file that relayed concern over F. Nearne's mental state and attempted to excuse his poor temperament. Maurice Buckmaster, head of the F Section, even wrote in June 1944 contesting the removal of F. Nearne, stating that the original report "was made at a time when Nearne had just escaped the Gestapo clutches and was terribly nervous." ${ }^{\circ 9}$ Buckmaster, thus, excuses both his poor performance and temperament on his service to the SOE — he aided as a courier to his sister J. Nearne and her organizer, HECTOR, before leaving for London. Yet, this same consideration was not given to Damerment, which clearly highlights the difference in gender expectations. While the personal character of female agents was blamed, the bad mental state of male recruits was excused as external forces. The recommendation of

\footnotetext{
${ }^{67}$ The National Archives HS 9/1089/3.

${ }^{68}$ The National Archives HS 9/1089/3.

${ }^{69}$ The National Archives HS 9/1089/3.
} 
one training instructor arguably best explains the difference in gender expectations between the men and women; "I agree that one should not occupy a valuable training space out of compassion, but would be extremely grateful if you would agree exceptionally to F. [Nearne's] going to SCOTLAND at least to see whether the Scotch air produces a change in his mental activity."70 It was this "compassion," the consideration of external forces, that was often denied to female recruits.

Overall, the training undergone by female agents was a complicated phase in their wartime experience. On one hand, they learned important technical skills that would aid in their time undercover work in France. On the other hand, however, training highlighted some of the fluctuating gender standards in the SOE. Women were praised for their behavior and their work, but training reports put their achievements in terms of gender expectations. Absentmindedness, vanity, aggressiveness and immaturity were gendered terms connected to negative female stereotypes. Such negative comments, especially when they were used harshly, reflected much about the male evaluators. Whether or not they were accurate descriptions of the female agents is harder to say.

Furthermore, the inconsistencies of valued traits for women versus men-like aggressiveness or attractiveness - had great consequences for future of women in the organization. Regardless of their technical capabilities, and despite the fact that both men and women underwent the same training, most women were relegated to the lowest levels in the SOE war work hierarchy. Therefore, even though gender norms were suspended to a degree in the SOE, such norms dictated the war work structure. As will be seen in the next chapter, while some women preferred their more subordinate war work-courier or

\footnotetext{
${ }^{70}$ The National Archives HS 9/1089/3.
} 
wireless operator-others succeeding in transcending the limited expectations given to them. 


\section{CHAPTER 3: WORKING IN THE SHADOWS}

The SOE attempted to reestablish a level of traditional gender norms through wartime assignments that relegated women to lower ranking positions; the reality of working behind enemy lines was far more complicated. As the demand increased for agents, female agents found the opportunity to gain additional authority and respect. Using war work as a lens to examine power dynamics in the SOE reveals the reassertion of power by women at the bottom of the chain of command; an altering of traditional power dynamics. This was accomplished when female agents demonstrated the irreplaceable value to both the individual circuit and the war effort of their participation in war. More importantly, women gained authority as women. They did not abandon traditional notions of femininity or attempt to fit a masculine mold as they gained influence within the SOE.

Before moving on to the specific wartime experiences of agents, however, it is important to reassess a key concept success as it applied to the SOE. In general, wartime alters peacetime conceptions of success, an already highly subjective term. The survival of the collective, the state, and the homefront supersedes the safety of the individual, in particular the soldier. This sentiment was best reflected in Alfred Lord Tennyson's famous poem “The Charge of the Light Brigade,” stating “'Forward, the Light Brigade!' Was there a man dismayed? Not though the soldier knew. Someone had blundered. Theirs not to make reply, Theirs not to reason why, Theirs but to do and die." ${ }^{\prime 1}$ Although Tennyson's British brigade faced mass slaughter and categorical defeat in battle, this

\footnotetext{
${ }^{1}$ Edgar Shannon and Christopher Ricks. "'The Charge of the Light Brigade': The Creation of a Poem." Studies in Bibliography 38 (1985): 1-44. http://www.jstor.org.libproxy.chapman.edu/stable/40371812.
} 
phrase is telling of the prototypical duty of soldiers. To obey orders even when faced with poor odds of survival. While the soldier as an individual may be driven by the hope to return home, the soldier as a collective loses his distinctive individualism in the mechanized war by sacrificing himself for the nation. The trade-off is his immortalization in the nation's memory, as Tennyson's poem indicates.

For SOE agents, who were warned from the beginning of the danger, survival was unlikely once they were deployed behind enemy lines. Their recognition of their poor odds, signaled a willingness to put the collective above the individual. The "Objects and Methods of Irregular Warfare," a portion of the SOE training syllabus, listed the agency's six overarching goals. Divided in political, economic and strategic aims, SOE agents were tasked with the following objectives:

(a) Politically. (i) To undermine enemy's morale and that of his collaborators. (ii) To raise morale of Occupied Territories. (b) Economically. (i) To damage enemy's material. (ii) To improve and augment our own material. E.g. By infiltration of weapons, explosives, sabotage equipment. (c) Strategically. (i) To damage enemy's man-power and communications. (ii) To improve our own manpower and communications. E.g. By infiltration of 'organizers', radio sets and operators, etc. ${ }^{2}$

These objectives were not achievable by any individual agent, rather they required a group. As such, success for an SOE agent meant the completion of a mission, the survival of the circuit, and the disruption of enemy forces. Capture, although tragic for the individual, only denoted defeat if it threatened these larger goals of the war effort. ${ }^{3}$

\footnotetext{
${ }^{2}$ British SOE, How to become a Spy: The World War II SOE Training Manual (New York: Skyhorse Publishing, 2015), 4-5.

${ }^{3}$ It is important to recognize that the SOE trained agents in the case of suspicion by the enemy led to personal/house searches and arrest. This both further illustrates the acknowledgement of the danger faced by agents and that capture did automatically mean failure. Rather it was an agent's response to capturethe ability to further subvert the enemy and to maintain the secrecy of the organization - that mattered. Capture did not mark an end to an agent's war work, rather it was a continuation in many cases. This idea will be explored further in Chapter 4.
} 
Moreover, the very nature of the SOE's work guaranteed a certain degree of failure, because of limited information and lack of control over circumstances. Whereas traditional militaries may be able to retreat, to request support, or to repel the enemy, these options were not always open for an SOE agent. While small skills such as weapons training could be useful, the ability to succeed in the field relied more on the ability of an agent to adapt to the circumstances and not falter in the face of unforeseen problems.

This was particularly true in the case of female agents as they arguably faced greater danger than some of their male colleagues due to their visibility to the enemy. Although some women took on increased responsibilities after deployment, most female agents acted as couriers or as W/T operators. In many ways, they served as the face of the SOE, since they interacted directly with other members of the allied resistance in France, taking greater day-to-day risks. Legally, these women were unlawful combatants—as discussed in chapter one - but the titles of courier and W/T operator suggest they engaged in non-combatant work. ${ }^{4}$

Their actual work as couriers and W/T operators, work deemed acceptable for women, highlighted several ironies. Women were delegated to these positions, in part, because of the perception that women needed to be separated from unnecessary violence. Tapping into the protector (men) versus the protected (women) dynamic explored by Kimberly Jensen's book Mobilizing Minerva, couriering and W/T operating presented

\footnotetext{
4 "The female agents of the SOE were seconded to the FANY, the First Aid Nursing Yeomanry, whose independent, voluntary and civilian status enabled the British authorities to circumvent the military regulations concerning women firing weapons to which the auxiliary services were subject." This quote reaffirms that even under the guise of an official military organization, the FANY, female agents were still civilians. Juliette Pattinson, “'Playing the daft lassie with them': Gender, Captivity and the Special Operations Executive during the Second World War," European Review of History 13, no. 2 (June 2006): 271-292, 272. DOI: 10.1080/13507480600785955.
} 
two jobs that were viewed as "non-combatant" because they did not require operating a gun, using explosives, or performing sabotage missions. ${ }^{5}$

Couriering and W/T operating, however, were far from safe. In fact, they were arguably the most dangerous positions, because of the visibility element. Both jobs required constant interaction with the world outside of the SOE, including the Gestapo. So, while the male agents acting as organizers and saboteurs were able to operate in the shadows, female agents walked — literally and figuratively — in the daylight.

The assignment of women to these two jobs, however, should not simply be put in terms of gender bias, because it ignores the capabilities of female agents. These women faced the danger of their position knowingly and carried out their assignments rather successfully, all the while proving their worth as agents and combatants. Through their intelligence, cleverness, and dedication, female agents found opportunities to advance in the SOE and assert power from the bottom.

\section{Couriering}

Twenty of the forty F Section female agents were classified as couriers. ${ }^{6}$ Couriering was the work with the least prestige in the SOE gendered war work hierarchy; yet, it was an integral aspect of the SOE's organization and success. The job title summons a banal image and while at times the work was tedious, difficulties also came with this position. Couriers moved between the clandestine world and civilian realm, simultaneously existing in both without belonging in either. Even though their successes were smaller and less spectacular than those of saboteurs, the contribution of female

\footnotetext{
${ }^{5}$ For further information see, Kimberly Jensen, Mobilizing Minerva: American Women in the First World War (Urbana, Chicago, and Springfield: University of Illinois press, 2008).

${ }^{6}$ The National Archives HS 8/442.
} 
couriers was invaluable as they passed along information and materials, and acted as a liaison between different groups.

According to the SOE training syllabus, "A courier supplies means of circumventing censorship by having messages carried by hand or verbally. Slow but surer than other methods. Message can be destroyed in emergency. On the other hand, if courier should be captured and interrogated, there may be imminent personal danger to several organizers."7 This depiction not only provides a basic description of the job of couriers, but also reaffirms both the danger faced by couriers and the perceived inferiority of this job—a woman's role — in comparison to organizers — a man's role traditionally_ in the circuit. Rather than expressing concern over the arrest - and potential violence of interrogation — of the female agent, SOE officials conveyed distress over the potential loss of male agents. ${ }^{8}$ By underscoring the threat of capture and interrogation, as well as recognizing the important information transmitted by couriers, this description also hints at the couriers' second-class status.

Elaine Plewman's file aptly depicts the overarching role of couriers, stating that "She travelled constantly, maintaining liaison between the various groups, acting as guide to newly arrived agents, and transporting W/T equipment and compromising documents." ${ }^{9}$ Even though the SOE training syllabus instructed that couriers not examine the content of information passed, to a certain extent this was difficult to accomplishespecially when intelligence was relayed verbally. Plus, as the communicator along various parts of the circuit, female couriers feasibly knew more than the average agent.

\footnotetext{
${ }^{7}$ British SOE, How to Become a Spy, 117.

${ }^{8}$ This also reaffirms the need to reevaluate standards of success in the SOE. While the loss of an agent was unfortunate, perhaps even mourned, the survival of the circuit was valued over the individual.

${ }^{9}$ The National Archives HS 9/1195/1.
} 
Regardless, the less a courier knew the better in case they were captured. Although the job of each woman varied based on the needs of the circuit, this description hits upon several of the main expectations women faced. One of the most important details gleaned from this excerpt is the extensive travel required of couriers.

Following the capitulation of France in May 1940, a few months prior to the establishment of the SOE, the country was divided into a northern German-Occupied territory and a southern French governed area, known as Vichy France. Acting as a puppet government run by Marshal Phillippe Pétain, Vichy France provided little resistance against the Nazi agenda—whether in terms of occupying Europe or enacting exclusion policies against the Jewish population. The first SOE circuits were sent to France in May $1941 .{ }^{10} \mathrm{~A}$ circuit was a group organization in a certain region and was composed of the following roles: organizer, lieutenant, arms instructor, saboteur, W/T operator, and courier, among other participants. ${ }^{11}$ During this period, only a handful of female agents were deployed to France. ${ }^{12}$ By the time that the SOE began readily recruiting women in 1942, Vichy France had been overrun by Axis forces-the division essentially eliminated—which had various implications for agents. Arguably the most important impact was that travel across the country was easier with the removal of the demarcation line. Yet, this also meant that German and Italian soldiers were stationed

\footnotetext{
${ }^{10}$ By the end of the war, there were ninety-two circuits that had operated in Occupied France. Not all of the circuits lasted from the time of their establishment to the end of the war, many experiencing periods of inactivity. For further information see Appendix H in MRD Foot, SOE in France: An account of the Work of the British Special Operations Executive in France 1940-1944 (London: Frank Cass, 2004).

${ }^{11}$ The National Archives HS8/998.

${ }^{12}$ The women sent to France during the division of country into two zones included: Giliana Gerson, Virginia Hall, Yvonne Rudellat, Blanche Charlet, Lise de Baissac, Mary Herbert, Odette Sansom and Marie-Thérèse Le Chene. For further information, see MRD Foot, SOE in France, 414.
} 
throughout the country, further increasing the risk for female couriers - as well as other SOE agents in general—who were constantly moving.

Traveling by train, bicycle, foot and car, female couriers' risk was significant due to the presence of enemy soldiers and check points. For instance, Jacqueline Nearne's "work involved train journeys all over Southern France and to Paris; on nearly every occasion she had to pass through German controls and was subject to lightning Gestapo checks on the trains. ${ }^{, 13}$ Check points were dangerous, because of the potential discovery of physical information transported by couriers. The longer that female agents worked in France and the more successful they were, the more "anxious [The Gestapo] were to locate and destroy the circuit with which [female couriers worked in]" as noted in the file of J. Nearne.

Similarly, Nancy Wake joined the FREELANCE circuit in May 1944 and went on several missions collecting information, both physical and verbal, engaging with other resistance members and moving materials. While the circuit was primarily located near Cantal in south-central France, Wake traveled hundreds of kilometers to other posts, such as Montlçon, Laroquebrou, and Chateauroux. At one point, Wake traveled "on foot...approximately $200 \mathrm{~km}$..." from Fridefront to Laroquebrou. ${ }^{14}$

Acting as liaisons, women met with other circuits, resistance members, civilians and military members. Samson was sent by her organizer "on a mission to MARSEILLE where she had to contact GILS and GISELLE and to take them a message from RAOUL...."15 The rescue of downed or captured Allied soldiers and airmen was also

\footnotetext{
${ }^{13}$ The National Archives HS 9/1089/4.

${ }^{14}$ The National Archives HS 9/1545.

${ }^{15}$ The National Archives HS 9/648/4.
} 
figured into their work as couriers often escorted members of the Allied military to safety. Wake travelled "by car from CHAUDESAIGUES [sic] to MONTLUÇON, accompanied by one armed man, and collected ANSELME [Lt. DUSSAC, U.S. Army]." ${ }^{\text {16 }}$ Similarly, Witherington "was responsible for the safe keeping of several escaped airmen." ${ }^{, 17}$

While interaction with other members of the SOE and the French resistance was part of the general job description for couriers, in some cases reports noted that the female agents were also sent because they were the best option. "Owing to her sang froid and presence of mind she [Andrée Borrel] was always chosen for the most delicate and dangerous work such as recruiting and arranging rendezvous, and she acted as cut-out for her commanding officer." ${ }^{18}$ Interaction with important members of the resistance or the Allied military demonstrates one of the ways that couriers - even though at the bottom of the hierarchy—asserted power upwards. Female agents were sometimes viewed as better liaisons than some of the male operatives, even organizers.

The Gestapo, however, presented a constant threat to a courier's safety. Pearl Witherington aptly summarized this in her oral history, asserting

I was terribly, terribly careful and very much awake to what was going on around me because you never know, wherever you were, in a train or a restaurant, if anybody was listening. An occupation is really one of the most awful thing[s] because you're just not at home. You have to be careful of everything. ${ }^{19}$

Yvonne Cormeau reiterated this concern when interacting with non-SOE members, "You never knew, man or women, who was prepared to give information to the Gestapo.

\footnotetext{
${ }^{16}$ The National Archives HS 9/1545.

${ }^{17}$ The National Archives HS 9/356.

${ }^{18}$ The National Archives HS 9/183.

${ }^{19}$ Bailey, Forgotten Voices of the Secret War, 186.
} 
Sometimes it was a personal vendetta between two families. Other times it was just for money." 20

The death of female couriers was essentially guaranteed if authorities discovered their direct participation in the resistance. Even if physical evidence of their resistance work was hidden in bags or on their person, a thorough search by Gestapo agents could easily lead to discovery. Odette Sansom's file highlighted this danger, stating that she "worked for six months in dangerous and trying conditions. The circuit to which she was attached was large, and she travelled widely, maintaining liaison between the various groups, delivering operational messages and transporting W/T equipment." ${ }^{21}$ Due to her travels, Sansom "was frequently stopped and searched by police and Gestapo..."22 Although Sansom's personnel file did not specifically state how she avoided capture, J. Nearne's file provides some insight to the ways in which Sansom and other female couriers were able to bypass enemy controls.

In a final report of J. Nearne's war work, her success was attributed to "Her resourcefullness [sic] and her complete understanding of the art of clandestinity $[s i c] \ldots$ and by her coolness and courage she set a most notable example to everyone with whom she came into contact." ${ }^{23}$ This excerpt alludes to the importance of behavior and character in the success of couriers when facing such dangerous obstacles.

This aspect of couriering, the constant travel and passing of German check points, demonstrates the innate danger faced by female agents, and the ingenuity of the women. While female agents were trained by the SOE to use guns and other weapons, agents

\footnotetext{
${ }^{20}$ Bailey, Forgotten Voices of the Secret War, 188.

${ }^{21}$ The National Archives HS 9/648/4.

${ }^{22}$ The National Archives HS 9/648/4.

${ }^{23}$ The National Archives HS 9/1089/4.
} 
were encouraged to rely on forms of defense that decreased further attention. As such, men and women were taught hand-to-hand combat and how to silently disarm an enemy. This training proved useful in the field, specifically seen in the case of Wake. When during a raid on a French factory Wake "'stepped up to [a German guard] and broke his neck,"” and noted that she "“was glad to find the method [taught in training] worked all right" ${ }^{24}$ Wake's ability to kill a German illustrates both her physical strength and willingness to participate in violence. In an interview with Juliette Pattinson, Wake further demonstrates her ruthlessness, “"All I wanted to do was to kill Germans.”,25 Although only one example of how female agents defended themselves in such dangerous positions, Wake's experience contradicts the wartime gender dichotomy that insists that women were incapable of such violent actions. Even though women like Wake may have been subjected to claims of sexual deviancy and defeminized, in an attempt to preserve the gender divide, female agents in the SOE complicate the narrative as they clearly take on traditionally feminine along with masculine traits.

Relying on violence, or force, to elude discovery was often unrealistic. Instead, the female agent's character often acted as her greatest weapon. One report noted Sansom's "outstanding coolness and complete disregard of danger." ${ }^{26}$ Although the statement "disregard of danger," presents a worrisome picture, as it alludes to a level of carelessness on behalf of Sansom, the author of this report feasibly meant to point out her bravery or fearlessness.

\footnotetext{
${ }^{24}$ Roderick Bailey, "Wake, Nancy Grace Augusta (1912-2011)" 2.

${ }^{25}$ Pattinson, Behind Enemy Lines, 62.

${ }^{26}$ The National Archives HS 9/648/4.
} 
The danger that came with every interaction, however, provided another opportunity for women to showcase their value. Not only because it demonstrated their bravery, but also because it highlighted their ingenuity when finding ways to overcome such difficulties. One report referenced Jacqueline Nearne's “common-sense and charm. Her sense of security was unequalled by anyone else in the field. She did a tremendous amount of unspectacular, hard and uninteresting work, which she always discharged faultlessly. I think the world of her. ${ }^{27}$ Such reports demonstrate the intelligence and courage inhibited by female agents, the command of which contradicts some of the negative reports given to female agents during training. More importantly, however, Jacqueline Nearne's praise underlines an important trait that women possessed and used to their benefit; their charm.

Utilizing their appearance, personality and mannerisms to manipulate others, female agents were able to successfully circumvent several problematic situations. Particularly, when coming across the Gestapo. Wake, for instance, played "'the part of a giddy Frenchwoman who didn't give a bugger what happened in the war...[She] was a good-time girl. [She] used to give Germans a date sometimes, sometimes three or four if [she] was away on a long trip and give them a little bit of hope. [She] played the part..." ${ }^{28}$ Sonya Butt, another courier, reiterated the success of charm in undermining Gestapo checkpoints, stating "'You just react to the moment and think, I'll get by alright with a nice smile. I just sort of smiled and waved to them. All the time...no matter what

\footnotetext{
${ }^{27}$ The National Archives HS 9/1089/4.

${ }^{28}$ Pattinson, Behind Enemy Lines, 149.
} 
you had hidden in your handbag or your bicycle bag, if you had a nice smile, you know, just give them a little wink." ${ }^{29}$

Playing upon German gender conceptions_-or misconceptions such situationsfemale agents both achieved at their missions and illustrated their value. By putting forth the most innocent version of themselves - whether that meant playing the part of a flirtatious young woman, or a demure woman blending in the background-female agents successfully passed through Gestapo check points and avoided extra attention. Furthermore, such actions qualified as a unique type of sabotage, only capable of being enacted by women. Taking advantage of the Gestapo in this way qualifies as a form of psychological subversion as it not only undermines the authority of the enemy, but also acted as a morale booster for witnesses. As referenced in her personnel file, Christine Granville rescued SOE agent Lt. Colonel Francis Cammaerts and two British officers, following their arrest in August 1944 in Digne, by “[waking] straight into Gestapo headquarters, [interviewing] the officials and by a mixture of bluff and strength of character [persuading] one of them to release the three [male] prisoners... and escape." ${ }^{\prime 30}$

This form of psychological sabotage was only accomplished by women. In no circumstance could a male agent flirt or charm a German soldier to get what they wanted. Although it would be a misrepresentation of the entire group of female couriers to say they used flirtation as a weapon, they did draw upon—whether intentionally or not— manipulated gender norms in their favor.

Although this paints a romanticized account of female couriers, at the end of the day they succeeded by passing information, communicating with others, and moving

\footnotetext{
${ }^{29}$ Pattinson, Behind Enemy Lines, 148-149.

${ }^{30}$ The National Archives HS 9/612.
} 
resources. The mode in which they accomplished such tasks was dictated by unpredictable circumstances and required the quick thinking of female agents. Ultimately, these assignments were crucial in the success of the circuit because they provided the funds, the arms, and the information to plan and to enact subversive plans against the Germans.

\section{Wireless Transmission Operators}

Wireless Transmission operation was the only wartime position that officially employed both men and women. ${ }^{31}$ Acting as a bridge in the SOE gendered war work hierarchy, placed above couriering but below the designated masculine roles, W/T operators were crucial components in communication. Wireless transmitters were "the only method for rapid communication and for obtaining immediate reply."32 Moreover, $\mathrm{W} / \mathrm{T}$ operators acted as the link between the homefront - London — and the battle fieldOccupied France. As such, they were valuable members in the circuit because they communicated need for materials and significant information back to headquarters, which ultimately impacted the capabilities of the individual circuit.

Drawing from the files of Eileen Nearne, Noor Inayat-Khan, and Yolande Beekman - all of whom were W/T operators in France - it is clear that, similar to female couriers, female $\mathrm{W} / \mathrm{T}$ operators were put in substantial danger-again upending presumptions about the protected status of women during war. In fact, female operators

\footnotetext{
${ }^{31}$ This position could be compared to that of nursing or medics in a traditional army. Close to the violence of the battlefield, these men and women shared the rank in status. This arguably had as many problems as it provided solutions. While women were able to participate in the war effort, because of the constant struggle between male and female medics/nurses/surgeons, it was unlikely that women be recognized. Particularly if men's ego and status is defined in opposition to women's role in society. For further information on this general concept, see Kimberly Jensen, Mobilizing Minerva: American Women in the First World War (Urbana, Chicago and Springfield: University of Illinois Press, 2008).

${ }^{32}$ British SOE, How to become a spy, 119.
} 
potentially faced greater danger because only male operators could claim military status and receive protections as prisoners of war. Pattinson explained this added protection provided to male agents in her article, “"Playing the daft lassie with them,"” when referencing Edward Zeff and Bob Sheppard's attempt to conceal their British SOE identities upon capture. While arrested male and female agents tried to claim to "[undertake] non-resistance acts," which would warrant less severe punishment, because of gender norms men could more easily pretend to be "[airmen] and blackmarketeer[s]."33 Zeff and Sheppard "“pretended at once to be pilots of the Royal Air Force. Could only speak English. We didn't know anything. And it went on rather well with the Germany Army who arrested us." ${ }^{34}$ According to Pattinson, since the Germans were aware of "escape lines" for downed Allied airmen in France, "[Zeff and Sheppard's] ruse worked and they were able to deceive the German soldiers who captured them....”35 Although Zeff eventually confessed under torture by the Gestapo, his ability to because pose as military personnel, provided a method to escape immediate death. ${ }^{36}$

During training, male and female agents underwent specialized instruction to become $\mathrm{W} / \mathrm{T}$ operators, learning the technical operation of the $\mathrm{W} / \mathrm{T}$ and the various codes needed to send and receive information. Although organizers were encouraged to be the sole decoder, the SOE recognized that "In some cases [W/T operators] may have to do the encoding and decoding." ${ }^{, 37}$ Thus, agents learned the various methods and types of

\footnotetext{
${ }^{33}$ Black-marketeers were those who participated in the black market in France. Pattinson explains that by confessing to a lesser crime than resistance work, such as partaking in the black market, agents could oftentimes avoid harsher punishment or suspicions of their connection to the SOE. Pattinson, "'Playing the daft lassie with them,"” 275.

${ }^{34}$ Pattinson, "'Playing the daft lassie with them,"” 275.

${ }^{35}$ Pattinson, "'Playing the daft lassie with them,"” 275.

${ }^{36}$ Pattinson, "'Playing the daft lassie with them,", 275.

${ }^{37}$ British SOE, How to become a spy, 209-221.
} 
codes used in the SOE; such as Playfair cipher and double transpositions. ${ }^{38}$ This required not only required the technical skills of how to use the W/T set, but also the memorization of such ciphers, both of which illustrate the intellectual prowess of an agent.

Furthermore, for security purposes each W/T operator held a unique keyword that was used to code and decode messages. For instance, Khan's keyword was "Complimentary." "39 Just as this acted as a security measure, however, it also feasibly increased the danger to which W/T operators were subjected. As Gestapo agents sought to stop SOE transmissions, capturing W/T sets was not enough for German counterespionage missions. These actions were only beneficial if the Gestapo had the keywords of agents, which required $\mathrm{W} / \mathrm{T}$ operators to be captured alive. As will be seen in the following chapter, the arrest of female $\mathrm{W} / \mathrm{T}$ operators had potentially disastrous consequences for both the circuit and the individual agent.

The Gestapo traced W/T operators with their own technology when illegal transmissions were broadcasted. As a result, "the more [the wireless transmitter] is used the more likely it is to be detected," according to the SOE training syllabus. ${ }^{40}$ Even though operators were instructed to take precautions - such as moving locations often, relying on others to move their equipment, and sending quick and concise messages - in the chaotic environment that these agents worked in, these precautions were not always

\footnotetext{
${ }^{38}$ Playfair cipher required the use of a five by five grid, in which letters would be placed into each boxexcluding one letter that was omitted. The agents' keyword would be entered first and the rest of the letters of the alphabet not already added in the grid. Once completed, this grid was used to code and decode messages based on a number of rules dictating the change of letters.

${ }^{39}$ The National Archives HS 9/836/5.

${ }^{40}$ British SOE, How to become a spy, 119.
} 
feasible. ${ }^{41}$ For example, although Yolande Beekman was assigned to a circuit in Lille, Beekman "was landed in the TOURS area and was obliged to make a dangerous journey alone via PARIS to LILLE, carrying her W/T equipment." ${ }^{42}$ If she had been caught carrying her W/T set during this four-hundred kilometer trip, there is little doubt she would have been arrested on the spot.

While the SOE attempted to implement certain safeguards to protect these female W/T operators, if an agent was traced by the Gestapo they had no feasible method of protection. The SOE training syllabus noted that $\mathrm{W} / \mathrm{T}$ operators were not to carry weapons, like their courier counter-parts, nor were official protection teams created to watch the operator. ${ }^{43}$ In a testimony of Beekman's arrest, a Frenchwoman noted that in the four months she operated in Lille, Beekman "[transmitted] about three times a week" and upon discovery she "had no "[protection team]." "'44 Whether Beekman should have moved more often or taken it upon herself to recruit lookouts is debatable; however, it is clear that this role was both incredibly dangerous. Moreover, unlike female couriers, W/T operators could not manipulate the Gestapo or Gendarmes with their charms once they had physical proof of illegal transmissions.

Completely avoiding dangerous scenarios, however, was impractical and as noted at the beginning of the chapter would potentially constitute a greater failure. Khan took a

\footnotetext{
${ }^{41}$ For further information regarding the precautions wireless transmitters were advised to take, see British SOE, How to become a spy, 125.

${ }_{42}$ The National Archives HS 9/114/2.

${ }^{43}$ Since the goal of female couriers and W/T operators was to remain inconspicuous, carrying weapons and traveling with other SOE agents, or resistance members, was unadvisable. If a female courier was passing through a German checkpoint with the possibility of being searched, having a weapon, let alone resistance related information, would be incredibly dangerous. Moreover, traveling in large groups of SOE agents or resisters would draw undesired attention to the courier or operator. Granted the decision to take either of these security measures was dependent on the circumstance and the agent's preference.

${ }^{44}$ The National Archives HS 9/114/2.
} 
significant risk to continue her work, when "During the weeks immediately following her arrival, the Gestapo made mass arrests in the Paris Resistance groups to which she had been detailed. She refused however to abandon what had become the principal and most dangerous post in France."

Of the eleven female W/T operators, six were arrested: Yolande Beekman, Yvonne Baseden, Denise Bloch, Noor Khan, and Eileen Nearne. Only Baseden and E. Nearne survived, demonstrating the significant dangers related to this work. Yet, the risks faced and importance of their contribution seems paradoxical to their inferior position in the SOE hierarchy. For example, Eileen Nearne had sent about "105 messages" in the five months she operated in the field. ${ }^{46}$ These messages provided crucial information regarding supplies needed to support the resistance, updates about the circuit and the region, and potential locations for supply drops. Beekman's “work made possible the delivery of arms and explosives to the resistance forces and coolness in face of the constant dangers and risk she underwent." ${ }^{17}$ In Khan's case, "For four months, she carried out her hazardous work in this most difficult and dangerous region, and by her efficiency and devotion to her work made possible the delivery of arms and explosives to the resistance forces and coolness in face of the constant dangers and risk she underwent." 48

While their official title alludes to a secretarial position, removed from the dangers of the battlefield, the circuits' capabilities and success depended on these female operators. Female authority was recognized by SOE officials in Khan's mission report.

\footnotetext{
${ }^{45}$ The National Archives HS 9/836/5.

${ }^{46}$ The National Archives HS 9/1089/2.

${ }^{47}$ The National Archives HS 9/114/2.

${ }^{48}$ The National Archives HS 9/114/2.
} 
The document states that "Although you are under [Cinema's] command and will take your instructions from him, you are the ultimate judge as regards the technicalities of W/T and W/T security." ${ }^{49}$ This communication highlights the authority possessed by female operators, demonstrating how they asserted power upwards in the hierarchy. Khan, Beekman, and Eileen Nearne illustrate how women challenged the traditional gendered war work hierarchy without necessarily taking on a different roles over the course of the war.

\section{Advancement}

Female couriers and W/T operators illustrated the advantages of their participation in the SOE flow of power. The women impacted the success of others above them in the SOE hierarchy even while clearly influenced by the decisions of commanding officials. That said, not all women operated exclusively in these two roles. Rather, due to the chaos of warfare - let alone irregular warfare - women gained the opportunity to expand upon their officially designated roles. In such circumstances, women further challenged traditional notions of the role of women in war.

Experience and demand played a significant roles in the advancement of female agents. Some took on higher ranking roles when agents holding the position were arrested, gaining the respect of their male peers in the process. Ultimately these women adapted while in the field, taking on the roles of organizers, co-organizer, lieutenant, arms instructors and saboteurs.

Odette Sansom temporarily took on a leadership role in March 1943 when "her commanding officer was away on a visit to England. ${ }^{, 50}$ During this period, Sansom was

\footnotetext{
${ }^{49}$ The National Archives HS 9/836/5.

${ }^{50}$ The National Archives HS 9/648/4.
} 
noted in a recommendation letter to have "arranged for several parachute deliveries of arms and equipment, and was always present on the reception ground to direct the operations. She also organised the reception of her commanding officer at very short notice and in a dangerous area, when he returned to France by parachute in early April." ${ }^{51}$ In addition to taking on the duties of organizer, Sansom continued her work as a courier. In her debriefing, Sansom stated that "From time to time she was still going to MARSEILLE to take and fetch messages from GILS and GISELLE because they had no radio. ${ }^{, 52}$ Sansom's multiple roles within the circuit demonstrates both the shortages in supplies in the field and how female agents adapted to the needs of the circuit, taking on the jobs they needed in order for the circuit to succeed.

Pearl Witherington also took on the role of organizer twice during her time in France. From October 1943 to January 1944 Withertington's commanding officer was out of the country, so she "took an active part in running the whole circuit, and was responsible for the safe keeping of several escaped airmen." ${ }^{, 53}$ Shortly after her organizer's return, however, "he and his W/T operator were arrested by the Gestapo" in May $1944 .{ }^{54}$ As a result, Witherington and Amédée Maingard, the radio operator and assistant organizer for the Stationer circuit, "split the enormous Stationer network into three sections. [Witherington] took the northern part of the Indre department, which she renamed Marie-Wrestler after two of her code names. ${ }^{, 55}$ Just a month before the Allied invasion of Europe, SOE circuits were called upon to prepare for the upcoming

\footnotetext{
${ }^{51}$ The National Archives HS 9/648/4.

${ }^{52}$ The National Archives HS 9/648/4.

${ }^{53}$ The National Archives HS 9/356.

${ }^{54}$ The National Archives HS 9/356.

${ }^{55}$ Pearl Witherington Cornioley and Hervé Larroque, Code Name Pauline: Memoirs of a World War II Special Agent, ed. by Kathryn J. Atwood (Chicago: Chicago Review Press, 2013), 81.
} 
onslaught. During this time Witherington organized both the circuit and the maquis group in the region, "acting as an arms instructor and planning concerted attacks on the enemy communications on D-Day.",56

On June 11, 1944, following D-Day, Witherington's circuit “[was] attacked by two thousand Germans... and the small maquis comprising approximately forty men, badly armed and untrained, put up a terrific fight, with the neighbouring communist maquis belonging to ALEX, which numbered approximately one hundred men." ${ }^{57}$ This attack became known as the Battle at Les Souches. According to Witherington's report, "This attack completely disorganized the set-up and we had to start from scratch again." Among the casualties, the circuit "had...no weapons and no radio" as everything was taken by the Germans during the attack. ${ }^{59}$ Yet, in the aftermath of the battle and the DDay landings, with definitive hope that the Allies could win against the Germans, "volunteers came flooding in [to the circuit]: locals, boys from youth camps, and a few who had been commandeered for the STO [Service du travail obligatoire, the compulsory work service, still operating in 1944] who didn't want to go to Germany and so joined the Maquis. ${ }^{, 60}$ Witherington noted that "At the end [they] had about 3,5000 men" join the Maquis connected to the circuit. ${ }^{61}$ At which point Witherington "organized them and had the idea of dividing the Nord-Indre Maquis [north Indre, the Marie-

\footnotetext{
${ }^{56}$ The National Archives HS 9/356. The maquis were French resistance fighters participating in guerrilla warfare against the Nazis. It is important to note that there were several groups of maquis, some of which clashed because of the difference in political leanings. Witherington noted in her memoir that there was a level of tension between communist marquis groups and non-communist marquis groups.

${ }^{57}$ The National Archives HS 9/356.

58 The National Archives HS 9/356.

${ }^{59}$ Cornioley and Larroque, Code Name Pauline, 84.

${ }^{60}$ Cornioley and Larroque, Code Name Pauline, 86.

${ }^{61}$ Cornioley and Larroque, Code Name Pauline, 86.
} 
Wrestler network] into four subsections. ${ }^{, 62}$ Although not trained as an organizer, Witherington adapted to fit into the role as best as possible.

The organization and control over the maquis was often difficult, making her success in doing so applaudable. This was reflected in her report, which stated that "[her] great difficulty in organizing the maquis was the lack of a military chief, who had to be French. ${ }^{, 63}$ Furthermore, due to her gender it is unlikely that all maquis members instantly agreed to her leadership role. Cornioley confirmed that "The fact that [she] was a woman was at times a handicap in instructing. The CLERMONT-FERRAND group would have preferred a man to instruct them. ${ }^{.64}$

Sansom and Witherington were exceptions, because the likelihood of women acting as organizers - the most valued position in the SOE circuit—was rare. Other women, however, were able to climb the ladder to significant positions. For instance, Borrel was regarded as "an able and devoted lieutenant, and was appointed second in command of the organisation." ${ }^{65}$ While originally dispatched as a courier, Borrel's participation in the circuit took on various roles. Not only was she responsible for upholding liaisons and "organizing parachute dropping operations," but she also "assisted in many acts of sabotage.." ${ }^{, 66}$ Even though several women found ways to further participate in the war effort, few directly engaged in sabotage.

Recognition on an official level was particularly important to validate the actions of female agents, and Borrel's war record was noteworthy. Her commanding officer

\footnotetext{
${ }^{62}$ Cornioley and Larroque, Code Name Pauline, 87.

${ }^{63}$ The National Archives HS 9/356.

${ }^{64}$ The National Archives HS 9/356.

${ }^{65}$ The National Archives HS 9/183.

${ }^{66}$ The National Archives HS 9/183.
} 
stating that "she is the best of us all. In J...'s absence she acted as my Lieutenant. Shared every danger. Took part in a December reception with myself and some others. Has a perfect understanding for security and as imperturbable calmness. Thank you very much for having sent her to me." ${ }^{67}$ Her worth as an agent and in the circuit was further cemented when she was listed as a "co-organizer" on her casualty report. ${ }^{68}$

Marguerite Knight was another courier turned saboteur, who "helped with arms inventories, parachutages $[\mathrm{sic}]$ and ran around." ${ }^{69}$ Moreover, she was noted as having done "a man's work there being no courier work... [Knight] did regular liaison work on a stolen bicycle...carried out one dangerous reconnaissance to Montargis...[and] Thereafter she made several reconnaissances for them...."70 Knight acts as an important example of how official occupation designations by SOE did not necessarily continue into the field. While the gender norms could largely be maintained during training, working in the field required agents — men and women — to adjust accordingly. To an extent, it was the unpredictability of irregular warfare that facilitated the alteration of traditional gendered war work.

Not only did Knight's war work exceed the expectations of the average courier, but she also "Carried on practically alone after the arrest of her organiser and his lieutenant. She ensured the carrying out of D.Day work in the Yonne and Côte d'Or...But for her, many [train] derailments would not have taken place."71 The ability for Knight to continue on with her work without her superiors further breaks down assumptions held

\footnotetext{
${ }^{67}$ The National Archives HS 9/183.

${ }^{68}$ The National Archives HS 9/183.

${ }^{69}$ The National Archives HS 9/849/7.

70 The National Archives HS 9/849/7.

${ }^{71}$ The National Archives HS 9/849/7.
} 
by society, and even in the SOE, that women needed to be handled by a man. ${ }^{72}$ Knight's experience was even more impressive when considering that she only underwent ten days of training. ${ }^{73}$

Gender was an important consideration for Knight's experience as she was often referred to as "one of the men." 74 One citation explaining this characterization, stating that "She marched with [the men] and took her [turn] at sentry with them, always as a volunteer. Or one occasion she marched 35 kilometres by night with a sabotage party...."75 Similar to Borrel, this quote alludes to Knight's acceptance into the circuit. While this was an example of the ability for women to be considered on a comparable level of male agents, such commendations also diminish the accomplishments of female agents as women. As seen throughout this chapter part of the success of female agents in France was due to their sex and gender performance. Thus, it would be an injustice to only define female agents' success in terms of their comparability to their male counter parts.

\section{Exceptions: Vera Atkins and Virginia Hall}

As seen throughout this chapter, female agents took on various roles that did not necessarily relate to their officially designated occupation when the need to fill vacancies arose. In a similar way, Vera Atkins and Virginia Hall assumed broad responsibilities within the F Section organization. Yet, because of the unique aspects of their war work, from an official stance, they do not completely fit into the categories discussed above.

\footnotetext{
${ }^{72}$ Several women received marks in their training reports that stated that they needed to be handled by a strong leader if they were to be effective in training.

${ }^{73}$ The National Archives HS 9/849/7.

${ }^{74}$ The National Archives HS 9/849/7.

75 The National Archives HS 9/849/7.
} 
Interestingly, however, their war work replicated the patterns of other female agents. In time their worth increased and resulted in a greater level of authority.

Atkins' final report surmised her role during WWII as "[having] worked in the French Section practically since its inception in March, 1941. Her duties have been those of Intelligence Officer, and adviser on current political events in France.. ${ }^{76}$ Since Hall was officially attached to the OSS, her role in the F Section was a bit less clear cut. "Her job was to provide intelligence about conditions etc. in France, to develop various contacts with a view to the resistance possibilities, to act as channel for transmission of instructions to F Section agents, and to look after agents generally," as surmised in Hall's personnel file. ${ }^{77}$ To a significant extent, these women held similar jobs in different locations - one on the homefront and the other behind enemy lines. Both women acted as mentors to other agents and participated in the dispersal of information.

Atkins and Hall began their work with the SOE in 1941. Atkins was hired in April 1941 as "Secretary in this Section," referring to the F Section, and Hall "started in August 1941 when she went to France with cover as Vichy correspondant [sic] of an American paper." ${ }^{, 78}$ Taking part in resistance work from the early years of the SOE, Atkins and Hall would gradually take on greater responsibility due to their expertise and became important players in the lives of other agents.

In October 1942, SOE officials at headquarters began calling for Atkins' promotion. One of the most notable supporters of Atkins as Maurice Buckmaster who was the leader of the F Section, one memo stating that Buckmaster asked

\footnotetext{
${ }^{76}$ The National Archives HS 9/59/2.

${ }^{77}$ The National Archives HS 9/647/4.

${ }^{78}$ The National Archives HS 9/59/2; The National Archives HS 9/647/4.
} 
to bring the case of Miss Atkins to your notice. She at present receives the top secretarial salary, but is serving in the capacity of an officer of the Section, and is considered very able and efficient... She has very good qualifications and is... a great asset to the F. Section. Her work is...equivalent in responsibility to any other woman officer in the Organisation. $^{79}$

Subsequently, Atkins was promoted from her secretarial position, which most women who worked in SOE headquarters held, to "an Intelligence officer" to the F Section. ${ }^{80}$

Following her promotion, which corresponded with the growing number of female agents, Atkins took on greater responsibilities. For instance, "She was responsible for passing to the B.B.C. the various messages upon which action was taken in the field, including the D-Day action messages." ${ }^{81}$ Atkins' most notable work in intelligence, however, was her dedication to tracking missing agents. As will be seen in future chapters, Atkins' war work extended past the dissolution of the SOE in January 1946 as she traveled to the continent to discover the fate of the agents captured while in France.

Hall, due to her direct deployment to wartime France, played a larger role in intelligence gathering. For instance, in two letters dated in June 1942 she wrote of the deteriorating situation for European Jews. In the first she relayed that "The Jewish question in Cracow has be [sic] fundamentally and drastically solved by this evolution of Cracow into a German City stop A Jewish quarter built on the other side of the Vistule, houses of eighteen odd thousand Jews who remain in the City but they are effectively isolated..." of the population while from Hungary comes the news that Jews will be completely

\footnotetext{
${ }^{79}$ The National Archives HS 9/59/2.

${ }^{80}$ The National Archives HS 9/59/2.

${ }^{81}$ The National Archives HS 9/59/2.

82 The National Archives HS 9/467/4.
} 
excluded from military service which comma in view of conditions on the Eastern front probably does'nt $[$ sic $]$ grieve them too much stop." ${ }^{.83}$ While summarizing the situation in Eastern Europe, Hall also explains the changing environment in Paris. She noted that "The Jews in Paris comma meantime comma are wearing the badge of their race.... a five pointed yellow star stop. ${ }^{, 84}$

Beyond their role in intelligence, Atkins and Hall both interacted closely with other agents. Atkins, in particular, took on a mentorship relationship with F Section men and women as "Hundreds of volunteers parachuted from ENGLAND were chosen, instructed and despatched $[s i c]$ under her personal guidance. ${ }^{, 85}$ Acting as a guiding figure to agents, Atkins "supervised the financial arrangements and private questions affecting officers leaving for the field, and invariably inspired them with the feeling that their requests would be attended to, whatever difficulties might arise." ${ }^{.86}$ Atkins also maintained a relationship with many of the families of agents. Agents could not disclose information about their whereabouts and their war work, and Atkins often acted as an intermediary to reassure families. This was particularly true following the disappearance of agents.

Although operating in the field, Hall was similarly recognized as a mentor of sorts for other agents in official documentation. "Practically every F Section agent sent to France during this period was in touch with her, and she helped them in every possible way, providing papers cover, etc. and looking after them when in difficulties," as noted in

\footnotetext{
${ }^{83}$ The National Archives HS 9/647/4.

${ }^{84}$ The National Archives HS 9/647/4.

${ }^{85}$ The National Archives HS 9/59/2.

${ }^{86}$ The National Archives HS 9/59/2.
} 
Hall's personnel file. ${ }^{87}$ This close interaction between agents resulted in Hall's loyalty to the F Section and the section's agents. Furthermore, this demonstrates Hall's authority within the field not only because agents were told to contact her, but also because of the increased level of her intelligence about the F Section due to her continual interactions.

When Hall was forced to leave France following the German invasion of Vichy France in November 1942, she was transferred to Spain to "indicate... safe houses and possible personnel for future recruitment. She will also take verbal and written messages in order to accelerate correspondence between Bilbao and Madrid. ${ }^{188}$ Yet, upon finding her work in Spain a dead-end, Hall wrote to Buckmaster to discuss a transfer back to France. Citing both the ineffectuality of her presence and her dedication to fellow agents, Hall wrote that "now [she has] had the luck to find two of my very own boys here and send them on to you. They want [her] to go back with them because we worked together before and our team work is good. ${ }^{, 89}$ Furthermore, she expressed her disappointment in her work in Spain, explaining that "When I came out here I thought that I would be able to help F. section people, but I don't and can't. I am not doing a job. I am simply living pleasantly and wasting time...my neck is my own, and if I am willing to get a crick in it because there is a war on...I think I can do a job for you along with my two boys." 90 Hall's response highlights both her dedication to the mission in France, willing to go beyond expectations, and her loyalty to other agents.

\footnotetext{
${ }^{87}$ The National Archives HS 9/647/4.

${ }^{88}$ The National Archives HS 9/647/4.

${ }^{89}$ The National Archives HS 9/647.4.

90 The National Archives HS 9/467/4.
} 
Hall returned to France in March 1944 "as organiser cum W/T operator with a roving mission in central France." ${ }^{91}$ Hall's new role as W/T, however, did not detract from her organizational authority. As part of her second mission in France, Hall "successfully organized a number of groups in [the Haute Loire district] until it was overrun by the Allied Armies. ${ }^{92}$

Overall, Atkins and Hall represent a unique sub-section of female SOE operatives. The pair, took on an unconventional roles for women in the organization, demonstrating both a dedication to the goals of the SOE and the agents in France. While not all SOE historians would group Atkins with the other female agents because she did not work in the field, her actions at headquarters influenced the agents in France. Moreover, as will be seen in the next chapter, Atkins' work did not end with the war. Rather she searched for missing agents, particularly the women, in Europe at the war's conclusion.

The war work of female agents in France challenged traditional conceptions about the relationship of women and war, and gender power dynamics. Women succeeded in the field, demonstrating that their womanhood was an asset rather than a hindrance, which counters ideas that women were incapable of participating in the violence of war. Additionally, rather than being separated from their male counterparts, women developed significant relationships with them and many women earned male respect as a result of their accomplishments. Overall, the women who maintained their roles as courier and W/T operator demonstrated their invaluable contribution to the war effort as the upper levels of the circuit faltered when these positions were vacant.

\footnotetext{
${ }^{91}$ The National Archives HS 9/647/4.

92 The National Archives HS 9/647/4.
} 
Although the war work presented in this chapter illustrates many of the successes of female SOE agents in France - highlighting their intelligence, loyalty and bravery—it is important to acknowledge that such achievements came at a high price. Capture, interrogation, and potential death were all concepts drilled into female agents; yet, even in captivity, the war work of female agents was not finished. Rather it was a continuation, perhaps an adaptation, of the work they accomplished in France. Arrest did not signal an end of the war for female agents, but rather further demonstrated their elite training and the strength of their character. Furthermore, the imprisonment of female agents and their experiences while in captivity — both in prisons and concentration camps — reveals their combatant status, contesting traditional notions of women's role in war. 


\section{CHAPTER 4: COMBATANTS IN CAMPS: THE ARREST AND DEPORTATION OF FEMALE AGENTS}

The term "combatant" conjures images of heroism on the battlefield, men in uniform leading the charge and risking their lives for the greater good. A combatant, however, is also a legal status, subject to the laws and regulations of war. ${ }^{1}$ As such, it is important to recognize the ways in which legal terminology contributes to how female agents classify as combatants.

The actual prosecution of war blurs the distinction between battlefields and homefront; combatant and non-combatant. Soldiers, sailors, and airmen who engage in violence on the battlefield are often distinguished from cooks, hard laborers, and mechanics. While the former supposedly faced danger daily, the men in the rear were seen as separate from the fighting. Yet, those divisions are misplaced. All were needed for victory, and so-called non-combatants often faced danger as well.

Basing combatant status solely on direct uniformed participation in the war effort is also imperfect. In WWII, governments called upon men, women and children on the homefront to contribute in multiple ways. Does working in a munitions factory constitute as direct participation, disqualifying factory workers as civilians? Or do they take up a quasi-status between civilian and soldier? What is the threshold required to move an individual from civilian to combatant? Legally, they still qualify as non-combatants; in reality, however, their categorization is ambiguous.

\footnotetext{
${ }^{1}$ For further information regarding the debate over defining combatant status by action versus semantics, see Charles H.B. Garraway, "'Combatants'-Substance or Semantics?" in International Law and Armed Conflict: Exploring the Faultlines: Essays in Honour of Yoram Dinstein, edited by Michael N. Schmitt and Jelena Pejic (Boston: Martinus Nijhoff Publishers, 2007): 317-334.
} 
This discussion is important because female SOE agents' combatant status—-both legally and in collective opinion-rests upon such definitions. While the titles of courier and $\mathrm{W} / \mathrm{T}$ operator suggests non-combative roles, as seen in the previous chapter; female agents directly participated in the war effort-frustrating the enemy and interfering in their ability to wage war - to such a degree that they effectively became combatants.

However, in terms of international laws of armed conflict, SOE agents qualified as unlawful combatants. They fell into the ICRC category of "all persons taking a direct part in hostilities without being entitled to do so and who therefore cannot be classified as prisoners of war on falling into the power of the enemy."," They were not considered prisoners of war upon capture - a status possessed only by lawful combatants—nor did they receive the protections accorded to civilians. This was a reality that these women knowingly accepted upon recruitment.

\section{Arrested and Imprisoned}

Of the thirty-nine agents sent into Occupied France, seventeen were arrested. ${ }^{3}$ Of these seventeen, fifteen were deported to concentration camps in Eastern Europe: specifically, Natzweiler, Dachau, and Ravensbrück. ${ }^{4}$ Ultimately, only three survived the camps - Yvonne Baseden, Odette Sansom, and Eileen Nearne - to tell their stories. From the time of the arrests to the end of the war, their overall poor treatment attests to their illegal combatant status. Although little information exists on the explicit treatment of each woman, because of their deaths and the cremation of their bodies-eliminating post-

\footnotetext{
${ }^{2}$ Solis, The Law of Armed Conflict, 223.

${ }^{3}$ Pattinson, Behind Enemy Lines, 155. Agents Arrested: Yvonne Baseden, Yolande Beekman, Denise Bloch, Andrée Borrel, Blanche Charlet, Madeleine Damerment, Mary Herbert, Noor Inayat-Khan, Cecily Lefort, Vera Leigh, Eileen Nearne, Elaine Plewman, Lilian Rolfe, Diana Rowden, Yvonne Rudellat, Odette Sansom, and Violette Szabo.

"Pattinson, "'Playing the daft lassie with them," 274-275.
} 
mortem evidence of specific mistreatment - it is not difficult to imagine the suffering that occurred. What is known of their experiences in captivity was due to both the personal accounts of surviving agents and the testimonies from captured Gestapo guards gathered by Vera Atkins while she was part of the Judge Advocate General (JAG) investigation of War Crimes after the war, which will be explored in the next chapter.

There were several French and German prisons where female SOE agents were sent; Avenue Foch, Fresnes prison, and Karlsruhe prison are among three of the places for captured SOE agents — men and women. Avenue Foch, located near l'Arc de Triomphe, was the Paris headquarters for the SS counter-intelligence service. According to historian Stephen Tyas, "interrogations of captured agents took place on the second floor, cells for the prisoners were on the top floor (the fifth floor)." ${ }^{, 5}$ To the south, Fresnes prison acted as another holding station and interrogation center; "the primary purpose of...detention at Fresnes was for Gestapo interrogation prior to being transferred to other prison and camp destinations, mostly in Germany." "Most of the female agents were held either at Avenue Foch or Fresnes prison, before being transferred to concentration camps or Karlsruhe prison, which was located near the Franco-German border.

When comparing the likelihood of capture between male and female agents, it becomes evident that women faced just as great danger, if not more. According to Pattinson, of the 441 men deployed to Occupied France, 104 were captured, meaning that twenty-four percent of the men were arrested. By comparison, forty-four percent of

\footnotetext{
${ }^{5}$ Stephen Tyas, SS-Major Horst Kopkow: from the Gestapo to British Intelligence, (United Kingdom: Fonthill, 2017), 154.

${ }^{6}$ Roderick Miller, "Fresnes Prison," Frank Falla Archive, accessed March 22, 2019, https://www.frankfallaarchive.org/prisons/fresnes-prison/. Although the research conducted by the Frank Falla Archives focus on the Channel Islanders resistance against the Germans, specifically those from Guernsey, based on the personnel files of female SOE agents and the testimonies of several Gestapo agents in the post-war period it is apparent that there was an overlap in experiences.
} 
female agents were captured in France. The tenure of agents in the field rarely spanned five months, let alone a year. Of the thirty-nine women stationed in France, only thirteen operated past five months. Even more grim, of the seventeen women arrested all but two spent a longer time in captivity than working in the field. The fact that nearly half of the F Section female agents were captured is staggering, most likely a result of their visibility to the enemy.

As couriers, female agents interacted with the enemy and the civilian population on almost a daily-basis. Elaine Plewman, for instance, was arrested on the $24^{\text {th }}$ of March 1944 while traveling with her organizer in Marseilles. ${ }^{7}$ According to an informant, M. Jean Hellet, Plewman walked into a trap set by the Gestapo, arriving at a fake rendezvous point in a flat on "Rue Merandet, Marseille [sic]." ${ }^{8}$ Female W/T operators, although not always physically visible, were easily tracked when sending out messages. Eileen Nearne was arrested on July 25, 1944 while working in Bourolareine. In a personal statement after the war, E. Nearne wrote, "I had just sent a message when through the window I saw the Gestapo arrive." " Luckily, because she managed to see the Gestapo approaching, she "had just [enough] time to burn the message and to hide the radio set." ${ }^{.10}$ While this may have protected the rest of her circuit from discovery, E. Nearne was still arrested.

Noor Inayat-Khan's arrest was not directly related to her visibility to the enemy, but to her presence in the civilian population. Although the Gestapo were acutely aware of Khan's presence and success as a W/T operator, they finally located her because she was betrayed. According to the voluntary post-war statement of Werner Ruehl, a guard at

\footnotetext{
${ }^{7}$ The National Archives HS 9/1195/1.

${ }^{8}$ The National Archives HS 9/1195/1.

${ }^{9}$ The National Archives HS 9/1089/2.

${ }^{10}$ The National Archives HS 9/1089/2.
} 
the Avenue Foch prison, "A Frenchwoman...came to the Avenue Foch and told KEIFFER [Ruehl's superior] that she was prepared against a sum of money, to betray a female agent who was staying in her flat." ${ }^{, 11}$ When tasked to arrest Khan, Ruehl noted that upon discovery Khan "quickly disappeared round a corner and we did not see her again. After a lengthy search we returned to the office. About two hours later I heard that MADELEINE [Khan] had, all the same, been arrested..."12 The possibility of betrayal was significant, whether by someone associated with the organization or by a French civilian, revealing the extreme risk taken by those-women in particular-visible to the outside world. Based on the post-war personal statement of Josef Goetz, a Gestapo agent in France, "As far as the French Section is concerned [the arrest of Khan was]...to the best of my knowledge, the only case where an arrest was made following a denounciation from a person not connected with the organisation." 13

Whereas E. Nearne had time to destroy her codes because she saw the Gestapo approaching, Khan — as well as other agents taken off guard — were not able to do the same. Even if the W/T was discovered, the destruction of an agent's codes meant that the Gestapo would have to rely on interrogation for information. ${ }^{14}$ Since Khan used the Frenchwoman's flat to send codes, the Gestapo “found a good deal of material which helped in her interrogation," according to Kieffer. ${ }^{15}$ Although Kieffer noted, in his voluntary statement at the end of the war, that Khan did not divulge any information,

\footnotetext{
11 The National Archives HS 9/59/2.

12 The National Archives HS 9/59/2.

13 The National Archives HS 9/59/2.

14 "The arrest of Inayat Khan resulted in a huge bonus for Kieffer as, contrary to security instructions —or her failure to understand these instructions before infiltration into France with her transmitter-the Germans found copies of all her back radio-traffic to and from London, complete with security checks." Tyas, SS-Major Horst Kopkow, 115.

${ }^{15}$ The National Archives HS 9/836/5.
} 
confiscated materials were often used by the Gestapo against the SOE. Josef Goetz "was in charge of decoy transmissions... When signals personnel were captured, I was present at the technical part of the interview... and had afterwards to give my opinion as to whether a decoy transmission was possible or not." ${ }^{.16}$ Khan's personnel file confirms that the Gestapo sent the decoy transmissions Goetz discussed; "[SOE HQ] had...suspected since early in 1944 that her transmissions were controlled by the Germans, probably since October 1943, and had continued to exchange telegrams with her in order to find out where the controlled circuit was located." ${ }^{17}$ There were, therefore, the potential longterm detrimental consequences when female agents were arrested.

Bad luck also resulted in the capture of female agents. Whether due to poor intelligence or poor timing, Madeleine Damerment "was captured on landing on 29 February 1944 near Chartres. ${ }^{, 18}$ In such situations, SOE training and individual capabilities made little difference. Damerment was subsequently interned in Fresnes prison until May 1944, after which she was deported to Dachau. ${ }^{19}$

Capture, however, did not necessarily represent the end of an agent's war work. Perhaps because they did not receive prisoner of war status and protection, the women were more likely to continue their rebellious behavior against their German captors. With little incentive to surrender peaceably and trained to hold out against interrogation for as long as possible, female agents adapted their work to fit their new circumstances.

\footnotetext{
${ }^{16}$ The National Archives HS 9/59/2.

17 The National Archives HS 9/836/5.

18 The National Archives HS 9/1654.

19 The Dachau concentration camp was located northwest of Munich and was "'the first concentration camp for political prisoners." " Prisoners faced forced labor, medical experimentation, and extermination while interned at Dachau. The camp was liberated by American forces on April 29, 1945. United States

Holocaust Memorial Museum, "Dachau," Holocaust Encyclopedia, accessed April 11, 2019, https://encyclopedia.ushmm.org/content/en/article/dachau.
} 
Keeping in mind that success for the SOE was partially defined by the survival of the whole, agents were trained on how to endure interrogation to provide other agents and the circuit the best chance of survival. SOE training broke down the types of interrogation by the status of the captor: the local police, the specialist police, and the Gestapo. ${ }^{20}$ The SOE provided instructions on how to best subvert enemy questioning. For instance, agents were told to "speak slowly, clearly and firmly. Do not answer simple questions immediately and hesitate with the more difficult ones" and "Avoid replies that lead to further questions. ${ }^{21}$ Like all training, however, the simulated environment did not always account for the actual experience of capture and interrogation. Rather, the SOE was feasibly reaffirming agents' morale, which is evident in their final comment that

If you are arrested by the Gestapo, do not assume that all is lost; the Gestapo's reputation has been built up on ruthlessness and terrorism, not intelligence. They will always pretend to know more than they do and may even make a good guess, but remember that it is a guess; otherwise they would not be interrogating you. ${ }^{22}$

The one piece of information divulged to agents, however, was particularly significant to the war work of female agents; "Do not be clever or abusive. Create impression of being [an] averagely stupid, honest citizen, trying his best to answer questions intelligently. Interrogators are not impressed by tears or heroics. ${ }^{, 23}$ This excerpt from the training lectures continued female agents' war work of playing a certain role to avoid scrutiny. Thus, female agents, once arrested, set about trying to convince their captors of their lack of involvement or unimportance.

\footnotetext{
${ }^{20}$ British SOE, How to become a spy, 82 .

${ }^{21}$ British SOE, How to become a spy, 84-85.

${ }^{22}$ British SOE, How to become a spy, 85.

${ }^{23}$ British SOE, How to become a spy, 85.
} 
Blanche Charlet, who was arrested in October 1942, took advantage of gender misconceptions while imprisoned. According to Pattinson, following the discovery of her codename, Charlet "pretended to faint, and when she recovered, pretended to play the part of a stupid woman who had wanted to play her glorious part in the resistance, but knew nothing about it." ${ }^{24}$ Playing into traditional notions that women "were too emotional to be involved in political activities," Charlet avoided both torture and deportation; eventually escaping from prison. ${ }^{25}$

MRD Foot, SOE's official historian, reaffirmed such strategies when recounting the capture of Eileen Nearne; "Nearne 'put on her act of being a sweet little thing who knew nothing she ought not' and that, consequently, she 'brought off a dexterous bluff, and persuaded the Gestapo she was only a foolish little shopgirl who had taken up resistance work because it was exciting. ${ }^{, 26}$ In addition to manipulating gender norms, E. Nearne was adept in concealing information. When interrogated, E. Nearne stated,

[The Gestapo] asked me questions about my code. I told them lies. They then took me to be interrogated and I said I was working on a double transposition code. They asked me how long I had been working as a W/T operator. I said three months and most of the codes were made up by my chief. They then asked me what organisation I worked for. I said I had joined in France and that I met my chief in a coffee shop and he engaged me there. ${ }^{27}$

The best deceptions were cloaked in half-truths, making the story easier to remember in times of stress. For instance, E. Nearne had operated in France for about three or four months before her arrest, and it is entirely possible that she used a double transportation code, a method of encryption taught during SOE training. That said, because the SOE

\footnotetext{
${ }^{24}$ Pattinson, "'Playing the Daft Lassie with Them,"” 277.

${ }^{25}$ Pattinson, "'Playing the Daft Lassie with Them,"' 277.

${ }^{26}$ Pattinson, "'Playing the Daft Lassie with Them,"” 277.

${ }^{27}$ The National Archives HS 9/1089/2.
} 
training syllabus stated that "Before leaving the operator receives a complete 'plan' containing scheds, call signs, etc... The operator must work in accordance with the 'plan' and any alterations must be sanctioned by the base," E. Nearne's assertion that her organizer created her codes was unlikely. ${ }^{28}$ This statement, regardless of its validity, however, was a cleaver move because it simultaneously downplayed her understanding of the work and discouraged further interrogation, prompting a shift to look for her organizer. Although it is unclear whether E. Nearne divulged any information, the Gestapo arguably learned about the organization of F Section circuits from prior interrogations.

It is also important to note that E. Nearne divorces herself from the SOE by claiming to be recruited in France. This small detail further distanced her from accusations of serious involvement in the resistance. The Gestapo resorted to torture and E. Nearne noted in a personal statement that "They put me in a cold bath and tried to make me speak but I stuck to the story." ${ }^{29}$ It was perhaps by chance that the Gestapo were unable to disprove her assertions, because when they went to confront her chief, after E. Nearne lied about their meeting spot, "an air raid warning was sounded" and E. Nearne noted that "he must have been delayed because of it." ${ }^{30}$ Due to E. Nearne's deception, her organizer was able to allude capture.

When arrested on April 17, 1943, Odette Sansom relied on femininity to aid in the continuation of her circuit. Betrayed by a member within the resistance, codename CHAILLAN, Sansom and her organizer, codename Raoul, were arrested at the Hotel

\footnotetext{
${ }^{28}$ British SOE, How to Become a Spy, 102-103.

${ }^{29}$ The National Archives HS 9/1089/2.

${ }^{30}$ The National Archives HS 9/1089/2.
} 
Glaiculles in Talloire, France. ${ }^{31}$ As the Gestapo searched the premise, Sansom was able to hide important information pertaining to their work; a pocket book that Sansom claims contained "three messages which had come by radio the same day for GILS and GISELLE and also for Captain MOREL. These messages concerned Captain MOREL's work and the work of the Maquis." ${ }^{32}$ Slipping the documents into her sleeve, upon leaving the building and "[entering] the car [Sansom] deliberately caught her stocking on the corner of the back seat so as to give her an excuse to touch her stocking and push the pocket book under the back seat." ${ }^{, 33}$ In doing so, Sansom hoped "that the pocket book would be hidden at least for a few hours and it would give some time for the news of their arrest to leak out, and various people would take precautions accordingly."34 Thinking of the survival of the collective, Sansom's deception depended on the excuse to check her stockings, which once again highlights how a female agent could use gender norms, a woman expressing concern over a stocking, to do her job. Lacking stockings, a male agent would have needed another cover to hide such important information.

Manipulation, however, took on several different forms and in the case of Sansom, she did not only rely on passive femininity, but purposeful authority. Her organizer's real surname was Churchill—although unrelated to the British Prime Minister, Winston Churchill. While he was hesitant to disclose such information, Sansom disagreed and believed that "the name might be somewhat of a protection...that it might influence the Germans. ${ }^{, 35}$ Acting as husband and wife, claiming the name of Churchill,

\footnotetext{
${ }^{31}$ The National Archives HS 9/648/4.

${ }^{32}$ The National Archives HS 9/648/4.

${ }^{33}$ The National Archives HS 9/648/4.

${ }^{34}$ The National Archives HS 9/648/4.

${ }^{35}$ The National Archives HS 9/648/4.
} 
Sansom was able to exercise some power when transferred to the Fresnes prison. In one instance, after being pulled out of bed and slapped in the face by a female S.S agent., Sansom requested to speak to the Captain-in-Charge of the prison and "gave her name as Mrs. CHURCHILL." ${ }^{36}$ Arriving shortly after, the German Captain "was full of apologies and did not want [Sansom] to think ill of all Germans, and was there anything he could do for her to make up for it?"37 Sansom attributed the Captain's, as well as other staff at the prison, accommodating behavior to her supposed surname. ${ }^{38}$

Her familial façade, however, did not protect Sansom from torture. According to her pension record, in the seven and a half month at Fresnes Sansom was "interrogated by the Gestapo on 12 different occasions; on occasions she was subjected to torture; the first time she had a red hot poker jabbed into her back; the second time her toe-nails were torn off. She was constantly threatened with worse treatment and was condemned to death twice. ${ }^{39}$ The mistreatment was so significant that her cellmate noted that

SANSOM had for many months been detained in solitary confinement in that prison and when she came to live with me her health was seriously impaired by this inhuman procedure so dear to the Nazis; her weakness was extreme: she could no longer even eat the small amount of filthy and repugnant food which was given to us. On some days she had not the strength to leave her paillasse... ${ }^{40}$

Despite her suffering, Sansom maintained an extraordinary level of dedication and power. Sansom's cellmate at Fresnes stated, "Convinced that she would certainly be shot, she said that she had for a long time accepted the sacrifice of her life which she had wished to dedicate without reservation to service of her country." ${ }^{41}$ Moreover, during one

\footnotetext{
${ }^{36}$ The National Archives HS 9/648/4.

${ }^{37}$ The National Archives HS 9/648/4.

${ }^{38}$ The National Archives HS 9/648/4.

39 The National Archives HS 9/648/4.

${ }^{40}$ The National Archives HS 9/648/4.

${ }^{41}$ The National Archives HS 9/648/4.
} 
interrogation, in which she was continually baited, her interrogator "said...that [Sansom] ought to be killed once for France and once for England," to which Sansom "retorted that they could only kill a woman once." ${ }^{42}$ Sansom's commanding presence continued after her imprisonment in France to her internment at Ravensbrück. ${ }^{43}$ Although suffering greatly, her intelligence and character arguably kept her alive.

Khan was another female agent who displayed great fortitude. Following her arrest, Khan was sent to Fresnes where she "twice attempted to escape. The first time through the bathroom and the second through the window of her cell," according to the testimony of Karl Haug, an employee at the prison. ${ }^{44}$ In a further act of rebellion against her captors, following her second attempted escape, she "again refused to give [her] word of honour not to attempt further escapes." 45

According to the testimonies of Gestapo agents who interacted with Khan, she did not provide any significant information. Ruehl stated that "I do not know of any other arrests which were made as a result of the arrest of MADELEINE [Khan].." ${ }^{, 46}$ Even after being moved from Fresnes to Karlsruhe, the Gestapo "had to ask Karlsruhe several times to reinterrogate Madeleine in connection with wireless transmissions 'Diana'. Once an official went from Paris to Karlsruhe to get some information from her...I am sure that in

\footnotetext{
${ }^{42}$ The National Archives HS 9/648/4.

${ }^{43}$ Ravensbrück was "the largest concentration camp for women in the German Reich," thus it is unsurprising that Sansom and other female agents were deported to the camp. As Baseden, Sansom and E. Nearne were sent to Ravensbrück for a period of time, the experiences of agents are more detailed. The Red Army liberated the camp in April 1945. United States Holocaust Memorial Museum, "Ravensbrück," Holocaust Encyclopedia, accessed April 11, 2019, https://encyclopedia.ushmm.org/content/en/article/ravensbrueck;

United States Holocaust Memorial Museum, "Ravensbrück: Key Dates," Holocaust Encyclopedia, accessed April 11, 2019, https://encyclopedia.ushmm.org/content/en/article/ravensbrueck-key-dates.

${ }^{44}$ The National Archives HS 9/836/5.

${ }^{45}$ The National Archives HS 9/836/5.

${ }^{46}$ The National Archives HS 9/59/2.
} 
this...she lied to us. We could never rely on anything she said."47 Similar to E. Nearne, as well as other agents, deception was not only an effective means to withhold important information, but also as a form of psychological resistance-frustrating German attempts at victory.

Khan, unsurprisingly, suffered for her subversive actions. While interned at Pforzheim prison, the Governor of the prison came into contact with Khan and "was told that she was to be treated in accordance with regulations for 'Nact und Nebel' prisoners. (Note; 'Nacht und Nebel' means Night and Fog. It was the expression used for people who 'disappeared' and once in custody were kept on the lowest rations, and in solitary confinement etc) and moreover, that she was to be chained hand and foot.",48

The brutality faced by female agents in prison varied significantly. Several Gestapo testimonies claimed that the women were treated fairly well. Joseph August Peter Placke, who was stationed at Fresnes prison and saw Khan and Borrel pass through, asserted "KIEFFER once told me that he believed the agents were held for exchange against German agents in England and I was obliged to believe it as all agents that I have seen were treated with particular consideration." ${ }^{49}$ At the end of his statement, Placke expressed "[surprise] and [shock] to hear that many were killed in concentration camps and do not believe that this thought occurred to KIEFFER."50 Granted, the truthfulness of such statements made by Gestapo agents while under Allied custody at the end of the war should be challenged. Under these circumstances, the Gestapo were incentivized to

\footnotetext{
${ }^{47}$ The National Archives HS 9/836/5.

${ }^{48}$ The National Archives HS 9/836/5.

49 The National Archives HS 9/59/2.

${ }^{50}$ The National Archives HS 9/59/2.
} 
understate the torture experienced. Moreover, with the lack of substantial proof to dispute their claims, these Gestapo agents could control the narrative.

That said, the statement made by Werner Emil Ruehl confirms the maltreatment capable during imprisonment, as seen in Sansom's case. Although he first worked at Rue des Saussaies in Paris and claimed to "not lay hands on any prisoner during" his tenure there, Ruehl admitted that the situation changed at Fresnes, stating that he "allowed [himself] to give way to maltreating prisoners, after we had been continually goaded...not to get soft and to carry out all interrogations with great severity." Stork, a driver working at Fresnes prison, noted that he "heard...that prisoners wer [sic] being beaten during interrogations," specifically noting "the bath method" employed by many interrogators. ${ }^{52}$ It is impossible to know the extent that female agents suffered in prison because of the lack of evidence, but the existence of other such stories reveals that Sansom's experience was not completely abnormal. That said, none of the women perished while held in prisons, which were just stops for female agents on the way to concentration camps in Eastern Europe, where fourteen of the seventeen arrested would ultimately die.

\section{Stories from the Camps}

While Sansom was aware of the increased possibility of death once she headed to a camp, not all agents were as conscious of the danger that lay ahead of them. Lili Simon, a female Gestapo agent who was employed at Karlsruhe, tracked the movements of some of the female agents who were held at the prison. Thus, Simon was acutely aware of what

\footnotetext{
51 The National Archives HS 9/59/2.

52 The National Archives HS 9/59/2. The bath method, "the cure," or "the 'baignoire," referred to was the "continual immersion in a bath of water until loss of consciousness." Stork stated, "I do not know of any cases where prisoners suffered from or died from the cure." The National Archives HS 9/59/2; Pattinson, "'Playing the Daft Lassie with Them,"” 279.
} 
the future held for these women, writing in her notes when an agent was "sentenced by Volksgerichtshof [the People's Court]' sometimes 'To Death." ${ }^{, 53}$ Simon knew that the prisoners had little understanding of their fate, rather they were told that "they were being taken to a camp and that they would be expected to work. The surrounding country was lovely and the women enjoyed it and looked forward to working. I did not know that they were being taken to a camp in order to be executed." 54 Simon may not have known that the women she was transporting would be executed, she nonetheless understood that it was a possibility and at the very least that the forced labor would be grueling.

Of the fifteen women deported to concentration camps in Eastern Europe, three went to Natzweiler, seven were sent to Ravensbrück, one was deported to Belsen and four were transported to Dachau. ${ }^{55}$ Since only three women survived, the information regarding their treatment while in concentration camps is limited.

Eileen Nearne, arrived at Ravensburg, but was moved to Torgau, Abteroda, and Makleberg before eventually escaping. ${ }^{56}$ E. Nearne's recollection of her time in the camps focused primarily on the forced labor. When told that she would be working in a factory, E. Nearne replied, "I did not want to work in the factory so they shaved my head and told me that if I did not work in 20 minutes I would be shot. I then decided to work." ${ }^{\circ 7}$ Once arriving in Makleberg—near Leipzig—in December, E. Nearne "worked on the roads for 12 hours per day and one day they told us we would be leaving the camp

\footnotetext{
${ }^{53}$ The National Archives HS 9/59/2.

54 The National Archives HS 9/59/2.

${ }^{55}$ The agents interned in each camp, respectively, were as follows: Andrée Borrel, Vera Leigh, and Elaine Plewman; Yvonne Baseden, Denise Bloch, Cecily Lefort, Eileen Nearne, Lilian Rolfe, Odette Sansom, and Violette Szabo; Yvonne Rudellat; Yolande Beekman, Madeleine Damerment, and Noor Inayat-Khan.

Pattinson, "'Playing the Daft Lassie with Them," 274-275.

${ }^{56}$ The National Archives HS 9/1089/2.

57 The National Archives HS 9/1089/2.
} 
for a place $80 \mathrm{~km}$. away," which provided the opportunity for her to escape. ${ }^{58}$ Running into and hiding in the forest with two other French girls, staying in a bombed out shelter and the woods, the three women were at one point "arrested by the S.S. who asked us for papers. We told them a story and they let us go." ${ }^{59}$ Following their arrival in Leipzig, the women were sheltered in a local church for three nights before "the first Americans [arrived]." ${ }^{60}$ While E. Nearne's time in captivity was surely trying, her brief time with the Americans in the post-war era-which will be explored in the following chapterpresented arguably the greatest frustration as she was placed in a camp as a potential threat. $^{61}$

Sansom, one of the only women with an extensive retelling of her time in captivity, suffered continually. Upon arrival at Ravensbrück in July 1944, she was immediately "put into an underground dark cell as a punishment. This was because of the [Allied] invasion of the South of France..."62 Sansom was confined to this cell for about three months. At one point "she was told that she would have no food to eat and for five days she was given nothing at all."63 This only changed after Sansom became delirious, and it was discovered that she had tuberculosis. True to her persistent character, however, she did not succumb to illness quietly. Rather, she demanded to see her X-rays and when denied she "made a great fuss and when the Camp Commandant came she demanded to see the plates." ${ }^{64}$ According to the physician, her condition was so poor that "if [she]

\footnotetext{
${ }^{58}$ The National Archives HS 9/1089/2.

${ }^{59}$ It is not stated in her personnel file what E. Nearne told the S.S. agents. The National Archives HS 9/1089/2.

${ }^{60}$ The National Archives HS 9/1089/2.

${ }^{61}$ The National Archives HS 9/1089/2.

${ }^{62}$ The National Archives HS 9/648/4.

${ }^{63}$ The National Archives HS 9/648/4.

${ }^{64}$ The National Archives HS 9/648/4.
} 
stayed in the cell she would be dead in two months." ${ }^{65}$ Once again relying on the name Churchill and her strong-willed personality to bend her captors, Sansom believed that "she managed to frighten the Germans by saying she was not German, etc. ${ }^{, 66}$ From that moment onwards, Sansom received treatment and better care from the camp doctor, which she "was convinced...was not done through any tender feelings for her, but simply to protect himself from retribution. ${ }^{, 67}$ This conviction was proven correct when she was repatriated “immediately prior to Ravensbrück's liberation in May 1945, the camp commandant, Fritz Suhren, still believing Sansom to be related to Winston Churchill, drove her to the American lines and tried to plea-bargain with American officials." ${ }^{68}$

Other than Baseden, E. Nearne, and Sansom, the other twelve women all died in the camps. Eleven were killed by firing squad, lethal injection, or gas, and were cremated immediately. Yvonne Rudellat, lived to see the liberation of Belsen—where she was held — only to die of disease waiting for repatriation. ${ }^{69}$

The imprisonment of these women contributes to the larger debate concerning the combatant status of female SOE agent. Although many of the women were treated poorly, and the next chapter debates the role of torture in their experiences, the capture and execution of the women adhered to international laws of war regarding unlawful combatants. The ability for some of the women to persevere in such horrid conditions, however, contributes to both their extraordinary characters and upends beliefs that women were too delicate for the violence of war. Rather, they fought—in whichever

\footnotetext{
${ }^{65}$ The National Archives HS 9/648/4.

${ }^{66}$ The National Archives HS 9/648/4.

${ }^{67}$ The National Archives HS 9/648/4.

${ }^{68}$ Pattinson, "'Playing the Daft Lassie with Them,"' 287.

${ }^{69}$ Pattinson, "'Playing the Daft Lassie with Them,"” 275.
} 
ways possible - to prove their power and ability to handle the greatest consequences of war. Pattinson contended in her article, "'Playing the Daft Lassie with Them,", that "For these women [imprisoned], who had all undertaken resistance roles with a distinct gender tag, perhaps 'equality' did start at the point at which combat stopped."70 True equality arguably was found in the execution of male and female agents as the death rate was nearly equivalent; seventy-eight percent of male agents perished in the camps and eighty percent of female agents died.

As the war came to a close, however, the experiences of female agents did not come to an end. As will be seen in the last chapter, the post-war era for surviving agents was defined by the reemergence of traditional gender norms and power dynamics.

Following the liberation of France in August 1944, Vera Atkins headed the SOE search for their missing personnel. Many of the surviving women struggled for recognition in the post-war era. The dissolution of the SOE in January 1946 officially closed the space in which these women both risked their lives and received recognition for their contributions. As the world began readjusting to peacetime gender dynamics, female SOE agents were expected to conform accordingly.

\footnotetext{
${ }^{70}$ Pattinson, "'Playing the Daft Lassie with Them,"” 279.
} 


\section{CHAPTER 5: AGENTS OR SPIES? MEMORY MAKING IN THE POST-WAR ERA}

A memorandum written by the U.S. Army on May 2, 1945, asserted

Subject creates a very unbalanced impression. She is often unable to answer the simplest questions, as though she were impersonating someone else. Her account of what happened to her after her landing near ORLEANS is held to be invented. It is recommended that Subject be put at the disposal of the British Authorities for further investigation and disposition. ${ }^{1}$

This report detailed the interrogation of Eileen Nearne following the liberation of the town in which she sought refuge after escaping from the Nazis. Since the U.S. Army did not believe her story, fearing that she was a "German agent," E. Nearne remained in U.S. custody, interned with other German women, for a month before she was released to British custody. E. Nearne, one of the three women who survived the Nazi camps in Eastern Europe, experienced early on the type of treatment of female SOE agents would receive in the post-war era. As the war in Europe came to a victorious close, the story of female agents did not end on a similarly positive note. Rather their work continued as many fought for recognition on an institutional level, seeking acknowledgement of missing agents and their wartime contributions.

The collective memory of the SOE and its female agents was shaped during the post-war period. Collective memory, which by nature is contentious and subjective, is the societal meaning attached to a historical event, that ultimately affects history's view of the people involved. Collective memory is important because it shapes the identity of a nation. ${ }^{2}$ As the actions of these women in France became known through public debate,

\footnotetext{
${ }^{1}$ ENearne_31.

${ }^{2}$ For further information regarding collective memory see The Collective Memory Reader, edited by Jeffrey K. Olick, Vered Vinitzky-Seroussi and Daniel Levy (Oxford: Oxford University Press, 2011).
} 
books, newspapers, films, oral testimonies, and memoirs, a narrative formed regarding both female agents' work and the role of women in war. Due to the number of deaths among agents and the desire of some surviving agents to return to their pre-war lives, female SOE agents were left out of the memory-making process. Rather the public's perception of the women is steeped in romantic visions of espionage, while still rejecting the combative role of women in war.

\section{Returning Home}

Demobilization for SOE F Section agents was particularly difficult because of the lack of procedure and the fact that agents who left the field prior to the liberation of France traveled to England. Of the original thirty-nine women deployed to France, twenty-seven returned to their homes. There is not a full report of their post-war lives, many preferring a secluded life after the war. Of the accounts provided, many of the women returned to civilian life to become wives, mothers, and workers.

Contesting narratives of sexual deviancy in female combatants, many of the women married, had children, and reentered society. For example, Sonya Butt fell in love with Guy d'Artois, a fellow SOE agent, and married in April 1944 before leaving for France. ${ }^{3}$ The couple was reunited following the liberation of Paris and "in late 1944, left for Canada...where the couple raised six children and settled in Montreal." ${ }^{, 4}$ Similarly, Witherington married childhood friend and SOE agent, Henri Cornioley, following the war. In her personnel file, Witherington's post-war occupation was designated as "Housewife-domesticated." Regardless of the abrupt language used to define

\footnotetext{
${ }^{3}$ Roderick Bailey, "D’Artois [née Butt], Sonia Esmée Florence [Toni] (1924-2014)," Oxford Dictionary of National Biography (15 February 2018): 2, https://doi.org/10.1093/odnb/9780198614128.013.108203.

${ }^{4}$ Bailey, "D'Artois [née Butt], Sonia Esmée Florence [Toni] (1924-2014)," 3.

${ }^{5}$ The National Archives HS 9/356.
} 
Witherington's post-war occupation, Butt and Witherington were just two female SOE agents that challenge the conception that the violence of wartime fully strips women of their femininity. It is important to recognize, however, that just because some of the women took on classically feminine positions in the post-war era, it does not mean that they did not also continue to assert themselves in the public sphere. Witherington becomes a clear example of this continuation, although limited, of authority into the postwar era, as she fights for recognition.

Many women found important jobs following the war as well. Nancy Wake returned to Australia after discovering that her husband had been killed during the war. Wake subsequently entered politics in 1949, and even though she never gained a position in the government, Wake's intention marks a continuation in her life of contesting gender occupational norms.

In Baissac's personnel file, a final report addresses her wish to find work following her release from the SOE; "[Baissac] will remain on the strength of this Section until 28.2.1945. By that time it is hoped that employment will have been found for her [unreadable]. If, however, they cannot make a firm offer, efforts will be made to secure alternative employment..." ${ }^{\prime 6}$ Although the specific position is unreadable in the document, Pattinson wrote about Baissac's employment as a French translator for the $\mathrm{BBC}$ following the war, which was a goal Baissac apparently had prior to the outbreak of WWII. ${ }^{7}$ This reference in her file does highlight the ways in which the SOE cared for their agents, some officials taking a particular interest in the future for the men and women - the latter probably more surprisingly—who volunteered.

\footnotetext{
${ }^{6}$ The National Archives HS 9/77/1.

${ }^{7}$ Pattinson, Behind Enemy Lines, 197.
} 
The SOE took a similar interest in Eileen Nearne, writing in her file that "we are anxious to see her reestablished in a suitable peace-time occupation. She is extremely keen to train in beauty culture and I have no doubt [she] will work very hard on making a success of it if she is given an opening." ${ }^{8}$ Similarly, Sansom and E. Nearne, who both suffered from physical and psychological maladies, received extra attentiveness to help them re-adjust to civilian life even though as a medical professional stated in one document "both [suffered] from psychological symptons [sic] which undoubtedly have been brought on by their service in the field. These symptoms interfere to a considerable extent with their efficiency for future employment and it is likely that they may continue to do so for some time to come."

Christine Granville, who operated in three different theaters of the war-Eastern Europe, France, and Cairo — was left to her own devices after peace. Granville wished to become a British citizen, rather than return to her home country, Poland. As one report noted, "[Granville's] situation is still difficult as her standing with her own people has undoubtedly been prejudiced by the fact that she has worked for [the SOE]." ${ }^{10}$ The author of the report asserts that because of her wartime work and contribution that the SOE was "under an obligation to pay her some sort of maintenance allowance until such a time as she can arrange to maintain herself." "11 Granville's application for citizenship, however, was rejected, unlike Vera Atkins, apparently because she was married to a foreign

\footnotetext{
${ }^{8}$ The National Archives HS 9/1089/2.

${ }^{9}$ The National Archives HS 9/1089/2.

${ }^{10}$ The National Archives HS 9/612.

${ }^{11}$ The National Archives HS 9/612.
} 
national. ${ }^{12}$ Granville was ultimately killed on June 15,1952 by one of her ex-lovers, Dennis Muldowney, while travelling. ${ }^{13}$

Jacqueline Nearne took on several roles in her post-war life, becoming both a worker and a caretaker. Juliette Pattinson noted J. Nearne "looked after her sister [Eileen Nearne] upon her release from Ravensbrück and then moved to New York to work with the United Nations."14 J. Nearne's post-war life reflects continuity with her wartime experience in terms of gender role delegation, as she became both a caretaker and a professional career woman.

While many women accepted and appreciated their post-war roles in the domestic sphere, other women challenged the dominating post-war narrative that diminished their contributions.

\section{Finding Missing Agents}

While a majority of the female F Section agents returned home to reintegrate into society, twelve women remained missing following the signing of peace treaties. Vera Atkins played a significant role in the post-war period, demanding that missing female agents not be forgotten. Following the end of the war in Europe, the SOE sought to "gather all possible information regarding the fate of those of its agents who were captured by the enemy and of whom many had vanished without trace in the latter stages of the Allied advance." 15 Atkins was at the forefront of this search, dedicating herself to tracking the missing men and women whom she had sent into field. In January 1945, Atkins was ordered to travel to France with "the task of tracing W.A.A.F. and R.A.F.

\footnotetext{
${ }^{12}$ The National Archives HS 9/612.

${ }^{13}$ Clare Mulley, The Spy Who Loved: The Secrets and Lives of Christine Granville (New York: St. Martin's Press, 2012), 327-329.

${ }^{14}$ Pattinson, Behind Enemy Lines, 199.

${ }^{15}$ The National Archives HS 9/59/2.
} 
Officer Agents who have been arrested and of whose fate [the SOE had]...no information." ${ }^{\prime 16}$ Primarily selected for this work because of her "long association with the W.A.A.F personnel appointed to this Department and her special concern with them whilst on this mission," Atkins war work continued beyond the end of wartime operations in France.

Despite the general consensus within the agency to search for missing agents, there was friction in regards to how to best accomplish this task and even the purpose for locating them. John Senter, the head of the SOE security section, pushed back against Atkins' investigation for several reasons according to Sarah Helm, who researched and wrote an extensive biography on Vera Atkins. ${ }^{17}$ Senter wished to interrogate the surviving agents about why and how so many circuits were infiltrated, following safety protocols to find them. In contrast, Atkin's wanted to circulate information about missing agents, arguing that "rules had been broken to get agents out there, particularly in the case of the women. Now rules had to be broken to get them back." ${ }^{18}$ Although it is unclear what specific safety protocols would be broken, arguably the problem with Atkin's plan to broadcast the identities of the agents was unwise because at this point the war was not over, so such actions could potentially risk exposing the missing agents. The worst consequence in this circumstance, especially if the agents were still hiding their identity, could be death. ${ }^{19}$ It was not until April 1945 that "the head of SOE's security

\footnotetext{
${ }^{16}$ The National Archives HS 9/59/2.

${ }^{17}$ Sarah Helm, A Life in Secrets: Vera Atkins and Missing Agents of WWII (New York: Nan A. Talese, 2005), 82-83.

${ }^{18}$ Helm, A Life in Secrets, 83.

${ }^{19}$ Odette Sansom, for instance, relied on the cover story that she was related to Winston Churchill, which she believes was the only reason the Germans kept her alive. As she kept up this ruse, she was repatriated by the Commandant of Ravensbrück in May 1945. Odette Marie Céline Sansom, interviewed by Conrad Wood, Imperial War Museum, October 31, 1986, interview 9478.
} 
directorate had sanctioned that short particulars of SOE agents should be published in the POW casualty lists... ${ }^{20}$ Even though Atkins' concerns about waiting to search for the missing agents was understandable, in reality, by the time the Allies crossed into Germany in March 1945, most of the women were already executed. ${ }^{21}$

Yet, when exploring this interaction between Atkins and Senter the question of gender emerges. Did Senter challenge Atkins purely out of security risks, or was he also affected by gender norms of the time, believing that she was incapable of handling such work? In response to Atkins' original proposal, which included distributing the names and descriptions of missing agents in hopes that as the Allied armies marched towards Berlin they may be able to locate the agents, Helm noted that Senter responded by saying, “"I think the set-up suggested in Vera Atkins's note, and the annotations, is frankly unworkable' ...adding that she should confine herself to 'welfare work.",22 Given the disparaging undertone of Senter's commentary, it is highly likely that Akins' gender played a significant role in the obstruction of her plan. Beyond potential security concerns, it was unlikely that her plan was significantly "unworkable," especially as the Allied armies marched towards victory. Senter's comment that Atkins should resign to "welfare work" further illustrates the return of gender biases. This vague language used by Senter alludes to the conception that women were best suited for work related to the domestic sphere, rather than the public and military sphere. As the F Section was steadily closing off, it was clear that shortly her high-ranking, respected position would be

\footnotetext{
${ }^{20}$ Helm, A Life in Secrets, 90.

${ }^{21}$ Borrel, Leigh, and Rowden were killed in July 1944; Beekman, Damerment, Khan, and Plewman were shot in September 1944; and Bloch, Lefort, Rolfe and Szabo were executed in January 1945. Pattinson, "'Playing the daft lassie with them," 274-275.

${ }^{22}$ Helm, A Life in Secrets, 82.
} 
eliminated. In such light, Senter's belittling comment can be interpreted as the slow return to traditional norms, coinciding with the nullification of Atkins' job.

The SOE officially dismantled at the end of 1945 and did not exist long enough to discover the fates of their missing agents. ${ }^{23}$ The discontinuation of the SOE signaled the end of the unique circumstances that allowed for female agency in the war effort. Atkins lamented this resolution in her oral history, expressing that "I think it tis in many ways most regretful that the decision was taken...before any real assessment could be made of [the SOE's] work or an ordered handover [of] what remained of historical interest or indeed any conclusion drawn from this work. ${ }^{24}$ Moreover, at this junction, there were still agents missing, "whose fate[s] one did not know... or the details of what happened." 25

Fortunately, the SOE arranged for Atkins to be attached to the J.A.G. War Crimes division to handle further investigation of missing agents. ${ }^{26}$ Driven by the hopes of providing answers to the missing agents" families, Atkins "was only interested in tracing the people who had gone to concentration camps and had not returned, and find out how and where they were killed."${ }^{27}$ Due to her role in the investigation and interrogation of German SS and Gestapo agents, Atkins participated in three war crimes trials;

\footnotetext{
${ }^{23}$ Vera May Atkins, interviewed by Conrad Wood, Imperial War Museum, January 6, 1987, interview 9552.

${ }^{24}$ Vera May Atkins, interviewed by Conrad Wood, Imperial War Museum, January 6, 1987, interview 9552.

${ }^{25}$ Vera May Atkins, interviewed by Conrad Wood, Imperial War Museum, January 6, 1987, interview 9552.

${ }^{26}$ The National Archives HS 9/59/2.

${ }^{27}$ Vera May Atkins, interviewed by Conrad Wood, Imperial War Museum, January 6, 1987, interview 9552.
} 
Natzweiler, Ravensbrück, and another unrelated case. ${ }^{28}$ Atkins, along with others who participated in these inquires, acted as the final defender of the lost female agents.

\section{Recognition in the Post-War World}

Medals and awards following military service represent a stereotypical method of recognizing combatants for their service and sacrifice during war. It not only reaffirms the government's acknowledgement of those who fought in its name, but also signals to the public the individual's service to the nation. Yet, few female SOE agents received such commendations. Instead, many of the commendations read, as seen in Elaine Plewman's file, as; "For her great gallantry and devotion to duty, it is recommended that Vol. PLEWMAN be appointed a Member of the Order of the British Empire. (Civil Division.)" ${ }^{29}$ This closing line demonstrates the paradox of the wartime experiences and post-war recognition of female SOE agents. Using language to depict the ideal traits of a combatant — bravery and loyalty — contradicts the civilian nature of this award. By receiving an award reserved for civilians, Plewman's combatant status during WWII is left aside in post-war memorialization. This commemorative approach both belittles female agents' contribution to the war effort and helps establish a narrative that these women were spies not soldiers.

There were four British awards that female SOE agents could receive, although the approval rates varied significantly: Member of the Order of the British Empire (M.B.E.), Officer of Order of the British Empire (O.B.E.), the George Cross (G.C.), and the George Medal (G.M.). Furthermore, M.B.E. and O.B.E. awards were distinguished

\footnotetext{
${ }^{28}$ Vera May Atkins, interviewed by Conrad Wood, Imperial War Museum, January 6, 1987, interview 9552.

${ }^{29}$ The National Archives HS 9/1195/1.
} 
between military (Mil.) and civil (Civ.) levels. According to the British government, the M.B.E. is "awarded for an outstanding achievement or service to the community. This will have had a long-term, significant impact and stand out as an example to others." ${ }^{, 30}$ The O.B.E. "is awarded for having a major local role in any activity, including people whose work has made them known nationally in their chosen area."31 The primary difference between the M.B.E. and O.B.E. is the rank of the individual, officers received the latter award. Both the George Medal and the George Cross were removed from the violence of war; making both military and civilian personnel capable of receiving this award. The George Cross "recognises acts of extreme bravery carried out by civilians and military personal when not under enemy fire. ${ }^{32}$ The George Medal followed similar guidelines to the George Cross, but was inferior in prestige. ${ }^{33}$

A majority of the women were relegated to the civil awards. ${ }^{34}$ Pearl Witherington, Christine Granville, Lise de Baissac, Marguerite Knight, and Elaine Plewman were all recommended for the O.B.E. (Civ.) medal. ${ }^{35}$ The female nominated for the M.B.E. (Civ.) included Eileen Nearne, Jaqueline Nearne, Odette Sansom, Virginia Hall, Andrée Borrel,

\footnotetext{
30 "Guide to the Honours," BCC online, published August 1, 2016, https://www.bbc.com/news/uk11990088 .

31 "Guide to the Honours," $B C C$ online, published August 1, 2016, https://www.bbc.com/news/uk11990088.

32 "How to Tell the Difference Between the Victoria Cross and the George Cross," Imperial War Museum, last modified May 30 2018, https://www.iwm.org.uk/history/how-to-tell-the-difference-between-thevictoria-cross-and-the-george-cross.

33 "Military Honours and Awards," accessed April 11, 2019, https://www.royal.uk/military-honours-andawards.

${ }^{34}$ Due to the limited information regarding commendations for $\mathrm{F}$ Section female agents the following names were limited to seventeen personnel records collected at The National Archives (TNA), as well as from Juliette Pattinson's book Behind Enemy Lines.

${ }^{35}$ The National Archives HS 9/356; The National Archives HS 9/612; The National Archives HS 9/77/1; The National Archives HS 9/849/7; The National Archives HS 9/1195/1.
} 
Anne-Marie Comert, Yvonne Baseden, and Sonya Butt. ${ }^{36}$ The two women who were awarded the George Medal were Nancy Wake and Christine Granville_-although Granville was put up for the award by the African Section of the SOE for her work prior to deploying to France. ${ }^{37}$

Noor Inayat Khan, Odette Sansom and Violette Szabo received the George Cross. ${ }^{38}$ The SOE occasionally attempted to recognize the women's combative role in the war, but the members of the British government that approved the recommendations did not always agree. For instance, Witherington was originally put up for the Military Cross in April 1945, although SOE's final executive director Major General Gubbins conceded in Witherington's recommendation that "If ineligible, it is equally recommended that she be appointed an Officer in the Order of the British Empire (Military Division)." ${ }^{39}$ Yet, according to Witherington, "I had been nominated for an MBE...But there are two categories of MBE, military and civil. I was on the civil list."40

Even though these medals could all be applied to military personnel, as well as civilians, the fact that they were specified as non-combative is troublesome when reviewing the wartime experiences of the women. Lise de Baissac and Witherington, frustrated by their exclusion from military awards, protested. Baissac wrote to Atkins, "The work which I volunteered to do in 1942 was of a military nature and later, when open warfare became necessary, we organised and carried out open attacks on the

\footnotetext{
${ }^{36}$ The National Archives HS 9/1089/2; The National Archives HS 9/1089/4; The National Archives HS 9/648/4; The National Archives HS 9/647/4; The National Archives HS 9/183; The National Archives HS 9/339/2; Pattinson, Behind Enemy Lines, 206-213.

37 The National Archives HS 9/1545; The National Archives HS 9/612.

38 The National Archives HS 9/836/5; The National Archives HS 9/648/4; The National Archives HS $9 / 1435$

${ }^{39}$ The National Archives HS 9/356.

${ }^{40}$ Cornioley and Larroque, Code name Pauline, 108.
} 
enemy... ${ }^{41}$ Witherington reflected a similar sentiment, specifically highlighting the fact that "Our training, which we did with the men, was purely military, and as women we were expected to replace them in the field... ${ }^{, 42}$ According to both women, their work was just as military as their male counterparts, who "received military decorations." ${ }^{43}$

To further complicate the memorialization process through awards, the rationale surrounding why agents received the George Cross over others is unclear. The three female agents who received this award — Khan, Sansom and Szabo — had overlapping similarities in their capture and torture, because as a memorandum in Sansom's personnel file stated, "[the citation for the George Cross] stands little chance of acceptance without: - (a) Medical evidence of maltreatment. (b) Witnesses of her refusal to speak under threat of torture, during torture and after torture." ${ }^{44}$ Acknowledging that the poor treatment of female agents contributes to their extraordinary character and war experiences, why is torture a significant prerequisite for earning the most prestigious of the four awards? Furthermore, what constitutes torture $?^{45}$ MRD Foot addressed this in one newspaper article, "Resistance Author Hits at Critics," declaring that it was a misconception that "people were given George Crosses simply because they were tortured, not because they

\footnotetext{
${ }^{41}$ The National Archives HS 9/356.

${ }^{42}$ The National Archives HS 9/356.

${ }^{43}$ The National Archives HS 9/356.

${ }^{44}$ The National Archives HS 9/648/4.

${ }^{45}$ Torture is one of the topics that one can identify when they see it, but when prompted to give a specific definition of what constitute torture is a far more difficult task. Is torture defined by the horrors inflicted upon the individual or by the fatality of the method? While the Gestapo agents interrogating SOE agents did not see the "baignoire" as lethal, although perhaps distressing, the agents feasibly thought differently. While the picture of Sansom clearly matches with connotations of torture - nails ripped out, solitary confinement, and burned - would the beatings sustained by all of the agents, according to Juliette Pattinson, illicit a similar reaction? While Foot is more concerned with historical accuracy, this discussion revolving around what constitutes as torture demonstrates the need for further discussion. According to Juliette Pattinson, beyond the beatings experienced by agents during interrogation, "Sansom had her toenails extracted and a poker laid on her spine, Eileen Nearne experienced the 'baignoire'....and Yvonne Baseden endured her bare toes being trampled upon by guards in army boots and a mock execution was staged." Pattinson, "'Playing the daft lassie with them,"” 279.
} 
were gallant far beyond the line of duty. ${ }^{, 46}$ Under this criteria Sansom, Khan, and Szabo were deserving, but it remains unclear why other women were deemed unqualified, such as Pearl Witherington. ${ }^{47}$

Szabo was a case in point. She was killed and cremated at Ravensbrück, so claims that she was tortured when arrested remained unsubstantiated. Thus, when R.J. Minney published Carve Her Name with Pride in 1964, which was an adaption from the film that was released in 1958, questions surfaced regarding the accuracy of Minney's portrayal of Szabo's brutal treatment while imprisoned. MRD Foot addressed the potential historical inaccuracies in his book SOE in France, published in 1966, in which he stated, "The reader will notice that awful as the sufferings of these women were, the allegations of fiendish brutality towards them by the Germans that are freely and frequently made are by no means all of them borne out be the facts. ${ }^{48}$ Minney took this statement as a personal slight, resulting in a lawsuit. The interactions between Minney and Foot aside, this passage from SOE in France raised questions about Szabo receiving the George Cross.

Following the publication of Foot's work, the public and media became involved in the discussion, expanding this dispute and shaping the memory of Szabo and other female SOE agents. David Creffield, author of "Violette, GC: Now they question her courage," specifically noted that Foot "alleges that the brutal tortures always accepted as imposed on Violette Szabo, the posthumous George Cross heroine of the film 'Carve Her

\footnotetext{
${ }^{46}$ The National Archives TS 58/1161.

${ }^{47}$ Although a note at the bottom of a draft of Witherington's recommendation for the award of the O.B.E., posited that the citation was first used for a George Medal recommendation. That said, the note was crossed out at some point, it is unclear when, and regardless Witherington did not receive the George Medal. The National Archives HS 9/356.

${ }^{48}$ Foot, SOE in France, 378.
} 
Name with Pride,' never happened. And that in the case of Mrs. Odette Hallowes [Sansom]...they have been exaggerated." ${ }^{49}$ Of course, the women still alive and the loved ones of the women who were killed during the war were shocked. Szabo's daughter expressed "I believe my mother was tortured in the same way that I believe she was very brave. I would like to think she wasn't tortured—it wouldn't in any way reduce my admiration for her." ${ }^{\prime, 50}$

In the case of Sansom, Foot was not only questioning the extent of her torture but also her sanity, asserting that "'Unfortunately [Sansom's] experiences in Ravensbruck had induced in her a state of nervous tension so severe that she had considerable trouble for many months in distinguishing fantasy and reality and it is likely enough that she got the two confused. ${ }^{, 51}$ In response, Sansom noted that she did in fact have her nails removed and stated that "'surely this is not in dispute." medical records within Sansom's personnel file confirm that she was tortured and was in considerable pain as a result.

Even the character of these women came under attack in the conversations revolving around the contribution of female agents in wartime France. Foot wrote that "[Sansom] was a Frenchwoman so combative that she had sacrificed the company of her three small daughters in England to go back to war by the early November felucca." ${ }^{, 53}$ As the primary memory-maker of the SOE, Foot's commentary on the female agents left a lasting impression. The language used in this statement highlights long-standing gender

\footnotetext{
${ }^{49}$ The National Archives TS 58/1161.

${ }^{50}$ The National Archives TS 58/1161.

${ }^{51}$ The National Archives TS 58/1161.

${ }^{52}$ The National Archives TS 58/1161.

${ }^{53}$ Foot, SOE in France, 188.
} 
dynamics. When men left their families to serve their country they were heroes, but women were considered sexually deviant due to both their wish to participate in war and their abandonment of the family or the domestic sphere.

Whether or not Foot—who as the official historian of the SOE had the power to shape how these women were remembered - was correct in being skeptical about claims to torture and suffering, this exchange revealed that the women did not necessarily have a voice in such conversations. The ability for women to push back against such poor portrayals of their character and their work was exceptionally limited. By the 1966, when the construction of memory was underway, fifteen of the F Section female agents were dead and their voices were essentially lost. ${ }^{54}$ Plus, similar to veterans of the Second World War, not all women wished to disclose their wartimes experiences. ${ }^{55}$ Society also obstructed the ability for all women to tell their stories. In October 1945, it was suggested to the SOE that former female agents from the F Section travel to the United States for propaganda purposes. Originally, the Wing Commander, who suggested the trip, decided upon Paddy O’Sullivan because of her M.B.E. award. Yet, SOE officials disagreed with the choice of O'Sullivan supposedly because "[she] had already received a considerable amount of publicity, was known to be very indiscreet and could not be relied on...to keep her mouth shut. She was also a citizen of Eire [Ireland]." ${ }^{, 56}$ Rather, Witherington was

\footnotetext{
${ }^{54}$ Eleven women were executed in concentration camps; Yvonne Rudellat died of starvation after the liberation of Belsen; Madeleine Latour Lavigne died from a blood clot in February 1945; Muriel Byck died from Menginitis in May 1944; and Christine Granville was murdered by her former lover in 1952. For further information see, Juliette Pattinson, Behind Enemy Lines: Gender, Passing and the Special Operations Executive in the Second World War (Manchester: Manchester University Press, 2007). ${ }^{55}$ Selwyn Jepson noted in his oral history that "All these years I have absolutely refused to talk about it because it brought back that life and death responsibility which I had so abhorred. My casualties were less than in the frontline infantry or any other frontline unit. They were still casualties." His comment illustrates the post-traumatic stress that resulted from war, regardless of whether the individuals were classified as combatants or civilians. Bailey, Forgotten Voices of the Secret War, 354.

${ }^{56}$ The National Archives HS 9/356.
} 
favored —along with Sonya Butt—because of her discreet nature and, arguably, her British nationality. The fact that nationality, which was of little consequence during the recruitment and deployment of agents, featured into this decision undercut the voice of certain agents. O'Sullivan could die for the SOE, but could not represent the organization that sent her to France.

\section{Fighting for Agency}

While there are several examples of how the female SOE agents were unable to represent themselves in the post-war era, there were a few marked instances in which the women tried to reclaim their stories. Primarily through memoirs, oral testimonies, and film, the surviving women were provided the opportunity to shape the memory of the female agents in France.

Of the remaining women, only a handful of the women wrote down their service in the SOE; Witherington, Wake and Comert. ${ }^{57}$ Yet, this provided the opportunity for these women to contribute to the collective memory in their own voices, which is particularly important as many of the details relayed are missing from other documents. The precision and accuracy of memoirs due either to self-censorship or misremembering details as time proceeds is less important for the purpose of this section than the significance of female agents asserting their authority over the memory-making process as the years went by.

Witherington spends the final chapters of her memoirs discussing the slights against her and fellow agents. She recalls both her civil award and the fact that she was

\footnotetext{
${ }^{57}$ Cornioley and Larroque, Code name Pauline; Nancy Wake, The Autobiography of the Woman the Gestapo Called the white Mouse (Melbourne: Macmillan, 1985); Anne-Marie Walters, Moondrop to Gascony (London: Macmillan, 1947).
} 
not officially allowed to wear parachute wings because she "“only jumped four times,"” three times during training and a fourth when parachuting into France. ${ }^{58}$ Yet, according to Witherington, "The SOE men all jumped four times in training and a fifth in operation, which gave them the right to wear wings, the parachutists' license for which you needed five jumps." 59 In Witherington's opinion, this was another way in which the government honored and rewarded the male over the female agents, and as an act of protest she wrote that "I didn't care. I had jumped, I went into operation; I was going to wear them..."60 Although seemingly a small detail, this admission along with the act of wearing parachutist wings pushed allowed for Witherington to assert her authority over the narrative. She was a combatant and she would not allow for others to tell her otherwise.

Oral testimonies were also a powerful way of, literally, giving the women a voice. Publically accessible through the Imperial War Museum, Atkins, Cormeau, Sansom and Witherington participated in this form of memory-making. Much like the memoirs, this source type gave the women a chance to engage in the conversations revolving around their wartime service. Atkins specifically addressed the debate revolving around Foot's work at the end of the interview;

well I think it is a really great pity that SOE in France was published before the author was enabled to see the people whom he would have wished to see, which included head-office staff like Col. Buckmaster and myself... and a much wider cross-section of agents. It is very discernable in the book...I can pick out those who he had seen as against those whom he had not seen. And it does leave an imbalance there. $^{61}$

\footnotetext{
${ }^{58}$ Cornioley and Larroque, Code name Pauline, 110.

${ }^{59}$ Cornioley and Larroque, Code name Pauline, 110.

${ }^{60}$ Cornioley and Larroque, Code name Pauline, 110.

${ }^{61}$ Vera May Atkins, interviewed by Conrad Wood, Imperial War Museum, January 6, 1987, interview 9552.
} 
While the interviewer injected that Foot limited by the Foreign Office restrictions Atkins nonetheless expressed frustration over what she saw as an incomplete record of the $\mathrm{F}$ Section that shaped the public perception of the organization.

Sansom similarly expressed joy over her ability to positively impact the memory of her fellow agents. When asked whether she was happy with the 1950 film "Odette," which was based on the biography Odette: The Story of a British Agent, she responded yes. ${ }^{62}$ Unconcerned about seeing an apt, personal portrayal, she "[wanted the public] to see the girls through the film." ${ }^{.63}$ This attitude was prompted by her post-war experience. According to Sansom, when she attempted to discuss the stories of other female agents the conversation "was always coming back to [her] because there [she] was and [she] could answer [the public's questions]." ${ }^{64}$ She subsequently "decided that the best thing to do was to try to give them some kind of publicity, which was started by the book...and the film, and after that by Violette Szabo...I was technical advisor on the film about Violette Szabo. So, it really started the ball rolling. ${ }^{, 65}$ As an ending note, Sansom asserted that "it was the only satisfaction I got out of all that." 66

Sansom's oral history conveys not only the significance of oral histories as vehicles of empowerment, the conversation also alludes to the role that films played in contributing to the collective memory. Films and television shows both informed the

\footnotetext{
${ }^{62}$ Odette Marie Céline Sansom, interviewed by Conrad Wood, Imperial War Museum, October 31, 1986, interview 9478.

${ }^{63}$ Odette Marie Céline Sansom, interviewed by Conrad Wood, Imperial War Museum, October 31, 1986, interview 9478.

${ }^{64}$ Odette Marie Céline Sansom, interviewed by Conrad Wood, Imperial War Museum, October 31, 1986, interview 9478.

${ }^{65}$ Odette Marie Céline Sansom, interviewed by Conrad Wood, Imperial War Museum, October 31, 1986, interview 9478.

${ }^{66}$ Odette Marie Céline Sansom, interviewed by Conrad Wood, Imperial War Museum, October 31, 1986, interview 9478.
} 
public about the female agents in the SOE and contributed to the shaping of public memory. Carve Her Name with Pride, 1958, and Odette were popular films that according to Sansom succeed in presenting an accurate picture of the war work undertaken in the F Section. Not all visual representations, however, were well received by the agents who were being portrayed. Wake challenged the perception of her character when a television show portrayed her cooking eggs and bacon. ${ }^{67}$ In response to this television drama on her wartime experiences, drawing from her memoirs, Wake asserted that "For goodness' sake, did the Allies parachute me into France to fry eggs and bacon for the men? There wasn't an egg to be had for love nor money. Even if there had been, why would I be frying it? I had men to do that sort of thing." 68

Charlotte Gray, released in 2002, is a more recent depiction of female SOE agents in France. While the film works to examine what it meant to be a woman in the F Section, overall it romanticizes the female agent experience. It focuses on the love interests that supposedly drive the female protagonist's participation in the SOE, and encourages the public to see the agents as spies rather than combatants. Even though this is a subtle difference, it is nonetheless vital. While the female agents were essentially spies, without nuance this perspective devalues their status as combatants, a dismissal made easier because of their gender.

In the post-war era, surviving female agents saw the return of traditional gender norms. Women returned to the domestic sphere and were compelled to leave their wartime contributions in the past. Going from a place where they could assert power and self-agency, female agents were left out of many of the discussions surrounding the

\footnotetext{
${ }^{67}$ Bailey, "Wake, Nancy Grace Augusta (1912-2011)," 3.

${ }^{68}$ Bailey, "Wake, Nancy Grace Augusta (1912-2011)," 3.
} 
collective memory of their wartime experiences. The memorialization of female agent's positive contributions during the war was frustrated by the commendation process and the public debates that mostly excluded the women. Even though traditional gender power dynamics were quick to return, the moments in which female agents pushed against the mainly male-prescribed narrative leaves a lasting impression of their strength in character. Regardless of the effectiveness of female resistance against gendered subordination in the post-war era, their ability to make their voices heard, even in the smallest ways, perhaps demonstrates some lasting remnants of the altered power dynamics that defined the SOE. 


\section{CONCLUSION}

In 2010, the New York Times published an article relaying the death of Eileen Nearne at 89 years old, dubbing her a "Wartime Spy." This article, as well as others written to extol the extraordinary stories of these women fails to grasp the larger significance of female agents' participation in WWII. Their remarkable story rests in the ways ordinary women altered — even if temporarily—gender power dynamics in war, thereby challenging ideas about women in war.

By contesting traditional conceptions of what women ought to do in war, female SOE agents demonstrate the multitude of ways wartime service can reinforce and challenge gender norms. The disruption of societal power dynamics during wartime therefore requires significant reconceptualization and what it means to be a soldier.

The participation of women in war was not a revolutionary idea when the SOE called for the mobilization of women and it was certainly not the last instance, especially as warfare drifted further from the traditional battle field. Women have been employed by national independence military organizations ever since for similar reasons, namely out of necessity and to gain a tactical advantage.

Algeria's war for independence (1954-1962) from French colonial rule included the mobilization of " 10,949 fighting women, $3.1 \%$ of all those taking part in active combat," according to Danièle Djamila Amrane-Minne who participated in the anticolonial fight led by the Front de Libération Nationale (FLN). ${ }^{2}$ These women filled

\footnotetext{
${ }^{1}$ John F. Burns, "Eileen Nearne, Wartime Spy, Dies at 89," New York Times, September 2010, https://www.nytimes.com/2010/09/22/world/europe/22nearne.html.

${ }^{2}$ Danièle Djamila Amrane-Minne and Farida Abu-Haidar, "Women and Politics in Algeria from the War of Independence to Our Day," Research in African Literatures 30, no. 3 (Autumn 1999): 62. DOI: 10.1353/ral.1999.0003.
} 
various roles, such as nursing, cooking, disseminating political propaganda and other supportive roles. ${ }^{3}$ Many of these jobs represent a continuation of traditional gender norms in Algeria prior to the war-subordinate to men and the French—but, that does not devalue their war work. ${ }^{4}$ Rather, Amrane-Minne noted that female participants were sometimes viewed as "the nucleus around which a whole support network revolved." Gender was also an advantage in the cities as "women fighters were becoming indispensable because they could easily mistaken for civilians. ${ }^{, 6}$ The combatant status of female fighters in Algeria is confirmed when they were captured, tortured and killed, similar to male fighters. Yet, Amrane-Minne asserted that while the men leading the FLN "accepted [women] on the battlefield...they could not come to terms with the idea of accepting them as equals."

During the Vietnam War (1955-1975), women partook in fighting against the United States. With no training, only “'provided with a knapsack, two sets of uniforms, a pot, and a tin can," women set out to work on the Ho Chi Minh Trail. ${ }^{8}$ Combating the environment, American air-bombings, and unexploded ordinances littered around the area, the women repaired the trail to ensure its usability by the North Vietnamese Military. Risking their lives as they maintained the trail, these women illustrate the

\footnotetext{
${ }^{3}$ Amrane-Minne and Abu-Haidar, "Women and Politics in Algeria from the War of Independence to Our Day," 64.

${ }^{4}$ Zohra Drif-Bitat, Andrew Ferrand, and Lakhdar Brahimi. Inside the Battle of Algiers: Memoir of a Woman Freedom Fighter (Charlottesville, Virginia: Just World Books, 2017), 41.

http://search.ebscohost.com.libproxy.chapman.edu/login.aspx?direct=true\&AuthType=ip, uid\&db=nlebk\& $\mathrm{AN}=1575673 \&$ site $=$ eds-live.

${ }^{5}$ Amrane-Minne and Abu-Haidar, "Women and Politics in Algeria from the War of Independence to Our Day," 63.

${ }^{6}$ Amrane-Minne and Abu-Haidar, "Women and Politics in Algeria from the War of Independence to Our Day," 65.

${ }^{7}$ Amrane-Minne and Abu-Haidar, "Women and Politics in Algeria from the War of Independence to Our Day," 67.

${ }^{8}$ Karen Gottschange Turner and Phan Thanh Hao, Even the Women Must Fight: Memories of War from North Vietnam (New York: John Wiley and Sons, 1998), 93.
} 
necessity and value of non-combative roles in warfare. One woman, Nguyen Thi Lieu was highly admired by the male soldiers on the trail because her work in disarming bombs, prompting one onlooker to note that "'Lieu had been given a male part to play.",9 The altering of gendered war work expectations, women performing highly dangerous work and the invaluableness of their participation on the war effort, further demonstrates the ways in which women continued to serve as combatants in wartime roles that remain unrecognized.

In 1990, Mozambique was in the middle of a Civil War that drew in the civilian population as the fighting moved into the cities. Carolyn Nordstrom, an Anthropologist at Notre Dame, traveled the country during this time and interacted with the local population. Driven by the question "What...is a female soldier" Nordstrom relayed the experiences of two women, Graca and Leenda. ${ }^{10}$ Graca transported "medicines, food, weapons, and other essentials" across battlefield lines, while Leenda acted as "one of the commanders in the area." ${ }^{11}$ Both of these women qualify as combatants, because of their level of participation in violence. Yet, the lack of legitimacy, both legally and in terms of memory, given to these women as combatants, arguably because gender norms prevent serious conversations about making women lawful combatants, obscures a true understanding of what it means to be a woman in war. Nordstrom aptly summarizes this concept, stating, "to be female today in a war zone is to be the frontlines." ${ }^{\prime 2}$ Even if recognized in war, however, peacetime does not guarantee their acceptance as an important contributor to society.

\footnotetext{
${ }^{9}$ Gottschange and Hao, Even the Women Must Fight, 113.

${ }^{10}$ Carolyn Nordstrom, "(Gendered) War," Studies in Conflict and Terrorism 28 (2005): 404.

${ }^{11}$ Nordstrom, "(Gendered) War," 405.

12 Nordstrom, "(Gendered) War," 404.
} 
Since the 1940s, women have been drawn closer into the violence of war. They are no longer just spectators, but participants in various and crucial ways. As this trend continues with women participating in both traditional militaries and non-state organizations, it is crucial to reexamine the relationship between women and war. If women join the war effort, regardless of the lawfulness of their combatant status, is it necessary to bring them into the fold? There are two potential pathways in which to examine this larger question. The first requires reconceptualizing gender expectations in war, mainly understanding that women can and do effectively participate in war. If governments and revolutionary forces continue to view — even if subconsciously because of social conditioning - women as an advantageous tool to be temporarily used in war, it is unlikely that roles of women in war will change.

The second is reconstructing our understanding of combatant and non-combatant. Even though the definitions of combatant and non-combatant are not perfect, they at the very least attempt to limit the horrors of war. Creating a grey area in the interpretations of these two classifications may provide women in war further legitimacy, but it also may increase the number of legitimate targets in war. By determining combatant status through war work, the proverbial Pandora's box may be opened. Without careful considerations about the multitude of thresholds between civilian and soldier, workers in an ammunitions factory could easily become lawful targets. Yet, by not giving women a legal status as combatants they suffer the consequences when they are deemed "illegal combatants."

There is no easy, nor just one, solution to these issues, but they require further analysis. The wartime experiences of female SOE agents in France, however, provide a 
paradigm to better understand these problems. Deployed as legitimate agents of the British government, these women proved that womanhood is not analogous with peace. The war work undertaken by these women clearly fell under the categorization of combatant and the agency exercised by the women during wartime and altered gender dynamics within the SOE.

The need for legitimacy—institutional and public recognition—is perhaps one of the most important take-aways from these female agents' stories. None of the women pushed for excessive authority and many did not ask for the responsibilities that came with leadership in a circuit in France. Nor did these women need to volunteer for further service as many of them were already part of an auxiliary force or had aided the French resistance prior to fleeing for England. Nonetheless, they chose to continually risk their lives. The women explored in this thesis did what they deemed necessary to win the war; often going above and beyond. Yet, in popular memory they are not recognized akin to the soldiers of WWII; they are "spies."13 Giving the F Section women the recognition of soldiers, validating their voices in the conversations surrounding their own actions, may be a first step in addressing this complicated relationship between women and war.

\footnotetext{
${ }^{13}$ Burns, "Eileen Nearne, Wartime Spy, Dies at 89," New York Times, September 2010, https://www.nytimes.com/2010/09/22/world/europe/22nearne.html.
} 


\section{APPENDICES}

Appendix A: Female SOE Agents in the F Section

\begin{tabular}{|c|c|c|c|c|}
\hline $\begin{array}{l}\text { Agent Name } \\
\text { (Last, First) }\end{array}$ & $\begin{array}{l}\text { Field } \\
\text { Name }\end{array}$ & $\begin{array}{l}\text { Function } \\
\text { Given }\end{array}$ & Circuit & $\begin{array}{l}\text { Time } \\
\text { Deployment }\end{array}$ \\
\hline $\begin{array}{l}\text { Agarzarian, } \\
\text { Francine }\end{array}$ & Marguerite & Courier & Physician (Prosper) & $\begin{array}{l}17 \text { March } \\
1943-J u n e \\
1943\end{array}$ \\
\hline Aisner, Julienne & $\begin{array}{c}\text { Claire, } \\
\text { Dominique }\end{array}$ & Courier & Farrier & $\begin{array}{c}14 \text { May 1943- } \\
\text { April } 1943\end{array}$ \\
\hline Atkins, Vera & $\mathrm{N} / \mathrm{A}$ & $\begin{array}{c}\text { Intelligence } \\
\text { Officer }\end{array}$ & $\mathrm{N} / \mathrm{A}$ & $\begin{array}{c}\text { April 1941- } \\
1946\end{array}$ \\
\hline Baseden, Yvonne & Odette & $\begin{array}{c}\mathrm{W} / \mathrm{T} \\
\text { operator }\end{array}$ & Scholar & $\begin{array}{c}18 \text { Mar 1944- } \\
\text { 26 June 1944; } \\
\text { Captured } \\
\end{array}$ \\
\hline $\begin{array}{l}\text { Beekman, } \\
\text { Yolande }\end{array}$ & Yvonne & $\begin{array}{c}\mathrm{W} / \mathrm{T} \\
\text { operator }\end{array}$ & Musician & $\begin{array}{c}18 / 19 \\
\text { September } \\
\text { 1943-15 Jan } \\
\text { 1944; Killed } \\
\text { September } \\
\text { 1944 at } \\
\text { Dachau }\end{array}$ \\
\hline Bloch, Denise & Ambroise & $\begin{array}{c}\mathrm{W} / \mathrm{T} \\
\text { operator }\end{array}$ & Clergyman & $\begin{array}{c}\text { 2/3 Mar } \\
\text { 1944-19 June } \\
\text { 1944; Killed } \\
\text { early } 1945\end{array}$ \\
\hline Borrel, Andrée & Denise & Courier & Physician (Prosper) & $\begin{array}{c}\text { 24/25 Sept } \\
\text { 1942-23 June } \\
\text { 1943; Killed } \\
\text { July } 1944 \text { at } \\
\text { Natzweiler }\end{array}$ \\
\hline Butt, Sonya & Blanche & Courier & Headmaster & $\begin{array}{c}28 \text { May 1944- } \\
\text { Oct } 1944 \\
\end{array}$ \\
\hline Byck, Muriel & Violette & $\begin{array}{c}\mathrm{W} / \mathrm{T} \\
\text { operator }\end{array}$ & Ventriloquist & $\begin{array}{c}\text { 8/9 April } \\
\text { 1944-May } \\
\text { 1944; Died of } \\
\text { Meningitis }\end{array}$ \\
\hline Carlet, Blanche & Christianne & Courier & Ventriloquist & $\begin{array}{c}\text { 1 Sept 1942- } \\
24 \text { Oct 1942; } \\
\text { Captured; } \\
\text { Escaped } 16 \\
\text { Sept } 1943\end{array}$ \\
\hline $\begin{array}{l}\text { Comert, Anne- } \\
\text { Marie (née } \\
\text { Walters) }\end{array}$ & Colette & Courier & Wheelwright & $\begin{array}{c}4 \text { Jan 1944- } \\
\text { Aug } 1944\end{array}$ \\
\hline
\end{tabular}




\begin{tabular}{|c|c|c|c|c|}
\hline $\begin{array}{l}\text { Cormeau, } \\
\text { Yvonne }\end{array}$ & Annette & $\begin{array}{c}\mathrm{W} / \mathrm{T} \\
\text { operator }\end{array}$ & Wheelwright & $\begin{array}{c}22 / 23 \text { Aug } \\
1943-23 \text { Sept } \\
1944\end{array}$ \\
\hline $\begin{array}{l}\text { Cornioley, Cecil } \\
\text { Pearl (née } \\
\text { Witherington) }\end{array}$ & Marie & Courier & Stationer/Wrestler & $\begin{array}{l}\text { 22/23 Sept } \\
1943-1944\end{array}$ \\
\hline $\begin{array}{l}\text { Damerment, } \\
\text { Madeline }\end{array}$ & Solonge & Courier & Bricklayer & $\begin{array}{c}29 \text { Feb 1944; } \\
\text { Captured } \\
\text { upon landing; } \\
\text { Killed Sept } \\
1944 \text { at } \\
\text { Dachau }\end{array}$ \\
\hline De Baissac, Lise & $\begin{array}{l}\text { Odile (1); } \\
\text { Marguerite } \\
(2)\end{array}$ & Courier & Scientist & $\begin{array}{c}\text { 24/25 Sept } \\
\text { 1942-Aug } \\
\text { 1943; 9 April } \\
\text { 1944-Aug } \\
1944\end{array}$ \\
\hline Fontaine, Yvonne & Mimi & Courier & Minister & $\begin{array}{l}25 \text { Mar 1944- } \\
16 \text { Sept } 1944 \\
\end{array}$ \\
\hline Gerson, Giliana & $\mathrm{N} / \mathrm{A}$ & N/A & N/A & $\begin{array}{c}\text { End May } \\
\text { 1941-June } \\
1941\end{array}$ \\
\hline $\begin{array}{l}\text { Granville, } \\
\text { Christine }\end{array}$ & Pauline & Courier & Jockey & $\begin{array}{c}\text { 6/7 Jul 1944- } \\
\text { French } \\
\text { liberation }\end{array}$ \\
\hline Hall, Virginia & $\begin{array}{l}\text { Marie (1); } \\
\text { Diane (2) }\end{array}$ & $\begin{array}{c}\text { Intelligence; } \\
\text { W/T } \\
\text { operator; } \\
\text { Organizer }\end{array}$ & $\begin{array}{c}\text { Heckler (1); Saint } \\
\text { (2) }\end{array}$ & $\begin{array}{c}\text { Aug 1941- } \\
\text { Nov 1942; } 21 \\
\text { Mar 1944- } \\
\text { French } \\
\text { liberation }\end{array}$ \\
\hline Herbert, Mary & Claudine & Courier & Scientist & $\begin{array}{c}31 \text { Oct } 1942- \\
18 \text { Feb 1943; } \\
\text { Captured; } \\
\text { Released } \\
\text { April } 1943\end{array}$ \\
\hline $\begin{array}{l}\text { Khan, Noor } \\
\text { Inayat }\end{array}$ & Madeleine & $\begin{array}{c}\mathrm{W} / \mathrm{T} \\
\text { operator }\end{array}$ & Cinema-Phono & $\begin{array}{l}16 \text { June 1943- } \\
\text { Oct 1943; } \\
\text { Killed Sept } \\
1944 \text { at } \\
\text { Dachau }\end{array}$ \\
\hline Julian, Ginette & Adèle & $\begin{array}{c}\mathrm{W} / \mathrm{T} \\
\text { operator }\end{array}$ & Permit & $\begin{array}{l}7 \text { June } 1944- \\
22 \text { Sept } 1944\end{array}$ \\
\hline $\begin{array}{l}\text { Knight, } \\
\text { Marguerite }\end{array}$ & Nicole & Courier & Donkeyman & $\begin{array}{l}6 \text { May } 1944- \\
13 \text { Sept } 1944\end{array}$ \\
\hline
\end{tabular}




\begin{tabular}{|c|c|c|c|c|}
\hline Latour, Phyllis & Geneviève & $\begin{array}{c}\text { W/T } \\
\text { operator }\end{array}$ & Silversmith & $\begin{array}{c}\text { 23/24 May } \\
\text { 1944-Aug } \\
1944\end{array}$ \\
\hline $\begin{array}{l}\text { Lavigne, } \\
\text { Madeleine Latour }\end{array}$ & Isabelle & Courier & Silversmith & $\begin{array}{l}23 \text { May 1944- } \\
\text { Aug 1944; } \\
\text { died Feb 1945 }\end{array}$ \\
\hline $\begin{array}{l}\text { Le Chêne, Marie- } \\
\text { Thérèse }\end{array}$ & Adèle & Courier & Plane & $\begin{array}{c}31 \text { Oct 1942- } \\
\text { Aug } 1943\end{array}$ \\
\hline Lefort, Cecily & Alice & Courier & Jockey & $\begin{array}{c}16 \text { June 1943- } \\
\text { 15 Sept 1943; } \\
\text { Killed Feb } \\
1945 \text { at } \\
\text { Ravensbruck }\end{array}$ \\
\hline Leigh, Vera & Simone & Courier & Inventor & \begin{tabular}{|c|}
14 May 1943- \\
20 Oct 1943; \\
Killed July \\
1944 at \\
Natzweiler \\
\end{tabular} \\
\hline Nearne, Eileen & Rose & $\begin{array}{l}\text { W/T } \\
\text { operator }\end{array}$ & Wizard & $\begin{array}{c}\text { 2/3 Mar } \\
\text { 1944-22 Jul } \\
\text { 1944; } \\
\text { Captured; } \\
\text { Escaped April } \\
1945\end{array}$ \\
\hline $\begin{array}{l}\text { Nearne, } \\
\text { Jacqueline }\end{array}$ & Jacqueline & Courier & Stationer & $\begin{array}{c}25 \text { Jan 1943- } \\
\text { April } 1944\end{array}$ \\
\hline $\begin{array}{l}\text { O'Sullivan, } \\
\text { Patricia }\end{array}$ & Simonet & Courier & Fireman & $\begin{array}{c}22 / 23 \mathrm{Mar} \\
1944-5 \text { Oct } \\
1944\end{array}$ \\
\hline $\begin{array}{l}\text { Olschanezky, } \\
\text { Sonia }\end{array}$ & Tania & Courier & Juggler & $\begin{array}{l}22 \text { Jan } 1943- \\
22 \text { Jan } 1944\end{array}$ \\
\hline Plewman, Elaine & Gaby & Courier & Monk & $\begin{array}{c}\text { 13/14 Aug } \\
\text { 1943-7 April } \\
\text { 1944; Killed } \\
\text { Sept 1944 at } \\
\text { Dachau }\end{array}$ \\
\hline $\begin{array}{l}\text { Reynolds, } \\
\text { Devereaux }\end{array}$ & Elizabeth & Courier & Marksman & $\begin{array}{l}18 \text { Oct } 1943- \\
20 \text { Mar } 1944\end{array}$ \\
\hline Rolfe, Lilian & Nadine & $\begin{array}{l}\text { W/T } \\
\text { operator }\end{array}$ & Historian & $\begin{array}{c}\text { 5/6 April } \\
\text { 1944-July } \\
\text { 1944; Killed } \\
\text { Jan 1945 at } \\
\text { Ravensbruck }\end{array}$ \\
\hline Rowden, Diana & Paulette & Courier & Acrobat/Stockbroker & $\begin{array}{l}16 \text { Jun 1943- } \\
18 \text { Nov 1943; } \\
\text { Killed July }\end{array}$ \\
\hline
\end{tabular}




\begin{tabular}{|c|c|c|c|c|}
\hline & & & & $\begin{array}{c}1944 \text { at } \\
\text { Natzweiler }\end{array}$ \\
\hline Rudellat, Yvonne & Jacqueline & Courier & Physician (Prosper) & $\begin{array}{c}\text { July 1942-21 } \\
\text { June 1943; } \\
\text { Died April } \\
1945 \text { in } \\
\text { Belsen }\end{array}$ \\
\hline Sansom, Odette & Lise & Courier & Spindle & $\begin{array}{l}\text { 31 Oct 1942- } \\
16 \text { April } \\
1943 ; \\
\text { Captured; } \\
\text { Repatriated } \\
\text { May } 1945 \\
\end{array}$ \\
\hline Szabo, Violette & Louise & Courier & Salesman & $\begin{array}{c}\text { 5/6 April } \\
\text { 1944-30 April } \\
\text { 1944; } 7 \text { June } \\
\text { 1944-10 June } \\
\text { 1944; Killed } \\
\text { Jan 1945 at } \\
\text { Ravensbruck }\end{array}$ \\
\hline $\begin{array}{l}\text { Wake, Nancy } \\
\text { (née Fiocia) }\end{array}$ & Hélène & Courier & Freeland & $\begin{array}{l}\text { 29/30 April } \\
\text { 1944-French } \\
\text { liberation }\end{array}$ \\
\hline Wilen, Odette & Sophie & $\begin{array}{c}\text { W/T } \\
\text { operator }\end{array}$ & Labourer & $\begin{array}{c}\text { 11 April } \\
\text { 1944-Aug } \\
1944\end{array}$ \\
\hline
\end{tabular}




\section{Appendix B: Traditional Gender War Work Hierarchy}

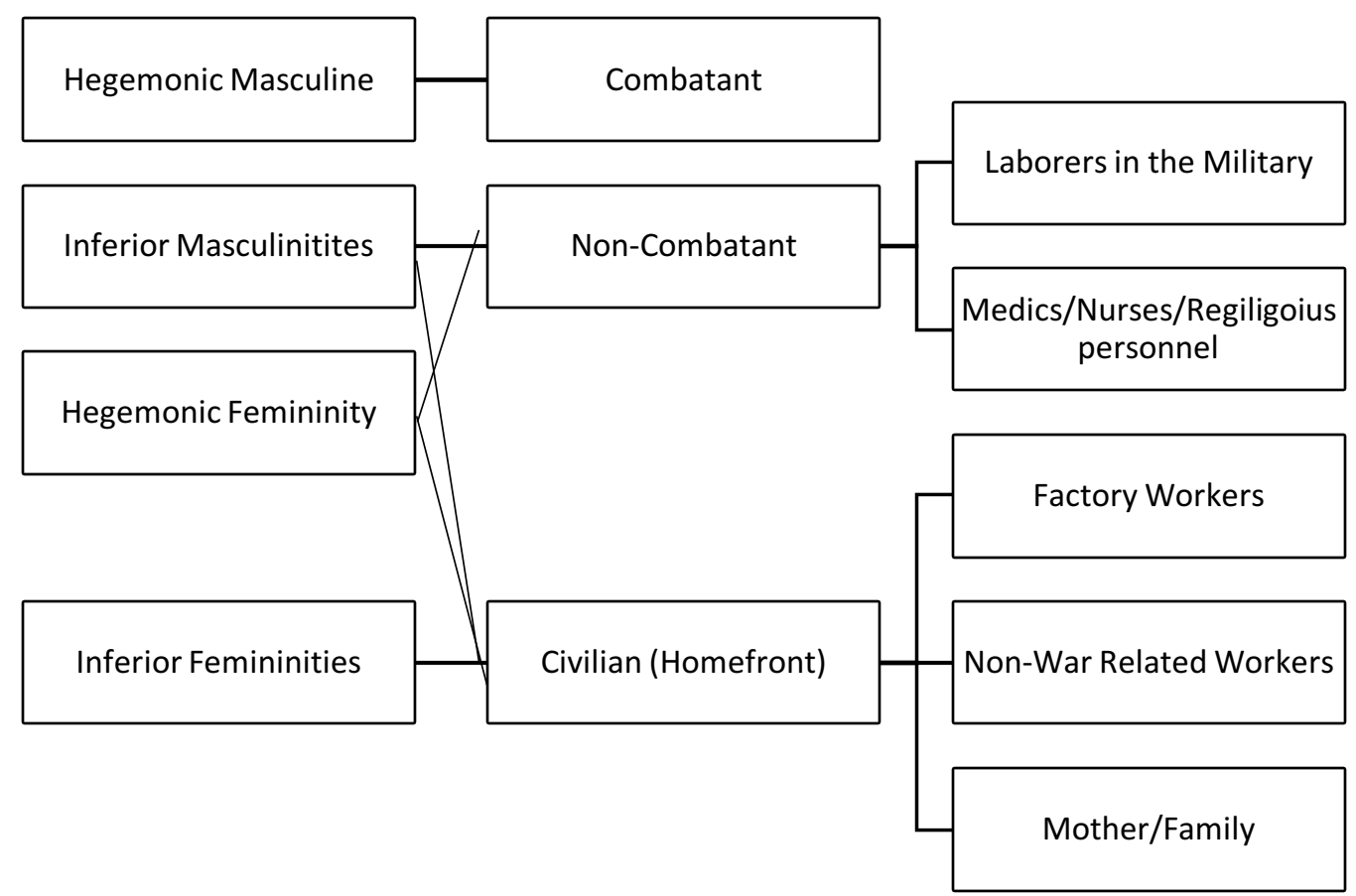




\section{BIBLIOGRAPHY}

\section{Primary Sources}

\section{Files held at the National Archives, Kew, London}

The National Archives HS 7/1 - History of SOE 1938-1945.

The National Archives HS 7/7 - Administrative Directorate and FANY Corps.

The National Archives HS 8/422 - Evaluations: SOE activities in France.

The National Archives HS 8/893 -Missing Agents Index; Concentration Camps.

The National Archives HS 8/998 - France: F Section Personnel; Circuits and Their Locations; OSS Personnel; Buckmaster Reseau Agents in the Field

The National Archives HS 9/55/6 - Personnel File, Hélène Berthe Aron.

The National Archives HS 9/59/2 - Personnel File, Vera May Atkins née Rosenberg.

The National Archives HS 9/77/1 - Personnel File, Lise Marie Jeanette de Baissac.

The National Archives HS 9/114/2 - Personnel File, Yolande Elsa Maria Beekman.

The National Archives HS 9/183 - Personnel File, Andrée Raymonde Borrel.

The National Archives HS 9/339/2 - Personnel File, Anne-Marie Comert née Walters.

The National Archives HS 9/356 - Personnel File, Cecile Pearl Cornioley née Witherington.

The National Archives HS 9/572/4 - Personnel File, Brunita Josepha Gemmeke.

The National Archives HS 9/612 - Personnel File, Christine Granville [also known as Kristina Gizyka].

The National Archives HS 9/647/4 - Personnel File, Virginia Hall.

The National Archives HS 9/648/4 - Personnel File, Odette Marie Céline Hallowes [also known as Odette Sansom].

The National Archives HS 9/653/1 - Personnel File, Joyce Amina Hanafy.

The National Archives HS 9/836/5 - Personnel File, Nora Inayat-Khan. 
The National Archives HS 9/849/7 - Personnel File, Marguerite Diana Francis Knight.

The National Archives HS 9/1089/2 - Personnel File, Eileen Mary Nearne.

The National Archives HS 9/1089/3 - Personnel File, Francis Nearne.

The National Archives HS 9/1089/4 - Personnel File, Jacqueline Francoise Mary Josephine Nearne.

The National Archives HS 9/1195/1 - Personnel File, Eliane Sophie Plewman née Browne-Bartroli.

The National Archives HS 9/1435 - Personnel File, Violette Reine Elizabeth Szabo née Bushell.

The National Archives HS 9/1453/4 - Personnel File, Odille Anne Marie Testelin.

The National Archives HS 9/1545 - Personnel File, Nancy Grace Augusta Wake.

The National Archives HS 9/1654 - Personnel File, Madeleine Zoe Damerment.

The National Archives TS 58/1161 - Objections raised about references to Violet Szabo, by R J Minney, the author of "Carve Her Name With Pride."

\section{Oral Histories held at the Imperial War Museum Sound Archive}

Atkins, Vera May. Interviewed by Conrad Wood. Imperial War Museum. January 6, 1987. Interview 9551.

Jepson, Selwyn. Interviewed by Conrad Wood. Imperial War Museum. July 3, 1986. Interview 9331.

Sansom, Odette Marie Céline. Interviewed by Conrad Wood. Imperial War Museum. October 31, 1986. Interview 9478.

\section{Memoirs}

Cornioley, Pearl Witherington. Code Name Pauline: Memoirs of a World War II Special Agent. Edited by Kathryn J. Atwood. Chicago: Chicago Review Press, 2015.

Wake, Nancy. The Autobiography of the Woman the Gestapo Called the White Mouse. Melbourne: Macmillan, 1985.

Walters, Anne-Marie. Moondrop to Gascony: An Account of the Author's Experiences in France during 1945 as a Member of the French Resistance. London: Macmillan, 1947. 


\section{$\underline{\text { Secondary Sources }}$}

Amrane-Minne, Danièle Djamila and Farida Abu-Haidar. "Women and Politics in Algeria from the War of Independence to Our Day." Research in African Literatures 30, no. 3 (Autumn 1999): 62-77. DOI: 10.1353/ral.1999.0003.

Anderson, Karen. Wartime Women: Sex Roles, Family Relations, and the Status of Women in World War II. Westport, CT: Greenwood Press, 1981.

Bailey, Roderick. "D’Artois [née Butt], Sonia Esmée Florence [Toni]: 1924-2014." Oxford Dictionary of National Biography. 15 February 2018. https://doi.org/10.1093/odnb/9780198614128.013.108203.

Bailey, Roderick. Forgotten Voices of the Secret War: An Inside History of Special Operations During the Second War. London: Ebury Press, 2008.

Bailey, Roderick. "Wake, Nancy Grace Augusta: 1912-2011." Oxford Dictionary of National Biography. 08 January 2015. https://doi.org/10/1093/ref.odnb/104083.

Behind the lines: Gender and the Two World Wars. Edited by Margaret Randolph Higonnet, Jane Jenson, Sonya Michel, and Margaret Collins Weitz. New Haven: Yale University Press, 1987.

British SOE. How to Become a Spy: The World War II SOE Training Manual. New York: Skyhorse Publishing, 2015.

Burns, John F. "Eileen Nearne, Wartime Spy, Dies at 89.” New York Times. September 2010. https://www.nytimes.com/2010/09/22/world/europe/22nearne.html.

Campbell, D'Ann. Women at War with America: Private Lives in a Patriotic Era. Cambridge: Harvard University Press, 1984.

Campbell, D’Ann. "Women in Combat: The World War II Experience in the United States, Great Britain, Germany, and the Soviet Union." The Journal of Military History 57, no. 2 (Apr. 1993): 301-323. https://www.jstor.org/stable/2944060.

Carve Her Name with Pride. Directed by L. Gilbert. 1958; United Kingdom; Angel Productions. DVD.

Charlotte Gray. Directed by Gillian Armstrong. 2001; United Kingdom: FilmFour and Warner Bros. [UK]. DVD.

The Collective Memory Reader. Edited by Jeffrey K. Olick, Vered Vinitzky-Seroussi and Daniel Levy. Oxford: Oxford University Press, 2011. 
Conover, Pamela Johnston and Virginia Sapiro. "Gender, Feminist Consciousness, and War." American Journal of Political Science 37, no. 4 (1993): 1079-099. doi:10.2307/2111544.

Crang, Jeremy A. "The revival of the British women's auxiliary services in the late nineteen-thirties." Historical Research 83, no. 220 (May 2010): 343-357. DOI: 10.1111/j.1468-2281.2008.00478.x.

Downs, Laura Lee. "War Work" in The Cambridge History of The First World War. Volume III. Edited by Jay Winter. United Kingdom: Cambridge University Press, 2016.

Drif-Bitat, Zohra, Andrew Ferrand, and Lakhdar Brahimi. Inside the Battle of Algiers: Memoir of a Woman Freedom Fighter. Charlottesville, Virginia: Just World Books, 2017.

http://search.ebscohost.com.libproxy.chapman.edu/login.aspx?direct=true\&AuthT ype $=$ ip, uid \&db=nlebk\&AN=1575673\&site $=$ eds-live .

Foot, M.R.D. SOE: An Outline History of the Special Operations Executive 1940-1946. London: British Broadcasting Corporation, 1984.

Foot, M.R.D. SOE in France: An Account of the Work of the British Special Operations Executive in France 1940-1944. London: Frank Cass, 2004.

Foot, M.R.D. “Was SOE Any Good?” Journal of Contemporary History 16, no.1 (1981): 167-81. http://www.jstor.org.libproxy.chapman.edu/stable/260622.

Elshtain, Jean Bethke. Women and War. New York: Basic Books, 1987.

Fieseler, Beate, M. Michaela Hampf and Jutta Schwarzkopf. "Gendering combat: Military women's status in Britain, the United States and the Soviet Union during the Second World War." Women's Studies International Forum 47, part A (NovDec 2014): 115-126. https://doi.org/10.1016/j.wsif.2014.06.011.

Fitzsimons, P. Nancy Wake: The Inspiring Story of One of the War's Greatest Heroines. London: Harper Collins Entertainment, 2002.

Garraway, Charles H.B. "'Combatants'-Substance or Semantics?” In International Law and Armed Conflict: Exploring the Faultlines: Essays in Honour of Yoram Dinstein. Edited by Michael N. Schmitt and Jelena Pejic. Boston: Martinus Nijhoff Publishers, 2007.

Gender and warfare in the twentieth century: textual representations. Edited by Angela K. Smith. Manchester: Manchester University Press, 2004. 
Gray, Colin S. "Irregular Warfare: One Nature, Many Characters." Strategic Studies Quarterly 1, no. 2 (December 2007): 35-57.

http://www.jstor.org.libproxy.chapman.edu/stable/26267370.

"Guide to the Honours." BCC online. Published August 1, 2016. https://www.bbc.com/news/uk-11990088.

Helm, Sarah. A Life in Secrets: Vera Atkins and Missing Agents of WWII. New York: Nan A. Talese, 2005.

"How to Tell the Difference Between the Victoria Cross and the George Cross." Imperial War Museum. Last modified May 30 2018. https://www.iwm.org.uk/history/howto-tell-the-difference-between-the-victoria-cross-and-the-george-cross.

ICRC. Customary IHL Database. https://ihldatabases.icrc.org/applic/ihl/ihl.nsf/ART/305-430004?OpenDocument. Accessed: January 16, 2019.

Jarvis, Erika. "Five Badass Female Spies Who Deserve Their Own World War II Movie." Vanity Fair. 25 November 2016. https://www.vanityfair.com/hollywood/2016/11/allied-world-war-2-female-spymovies.

Jensen, Kimberly. Mobilizing Minerva: American Women in the First World War. Urbana, Chicago, and Springfield: University of Illinois Press, 2008.

Kaplan, Marion A. "Revealing and Concealing: Using Memoirs to Write German-Jewish History." In Text and Context: Essays in Modern Jewish History and Historiography in Honor of Ismar Schorsch. Edited by Eli Lederhendler and Jack Wertheimer. New York: Jewish Theological Seminary of America, 2005.

Kramer, R. Flames in the Field: The Story of Four SOE Agents in Occupied France. London: Penguin, 1995.

Lee, Janet. War Girls: the First Aid Nursing Yeomanry in the First World War. New York: Manchester University Press, 2005.

Mackenzie, William. The Secret History of the SOE: The Special Operations Executive 1940-1945. Great Britain: St. Ermin's Press, 2000.

Milkman, Ruth. Gender At Work: Dynamics of job Segregation by Sex during World War II. Urbana: University of Illinois Press, 1987.

“Military Honours and Awards.” Accessed April 11, 2019. https://www.royal.uk/military-honours-and-awards. 
Miller, Roderick. "Fresnes Prison," Frank Falla Archive, accessed March 22, 2019, https://www.frankfallaarchive.org/prisons/fresnes-prison/.

Mulley, Clare. The Spy Who Loved: The Secrets and Lives of Christine Granville. New York: St. Martin's Press, 2012.

Nordstrom, Carolyn. “(Gendered) War.” Studies in Conflict \& Terrorism 28 (2005): 399411. DOI: $10.1080 / 10576100500180410$.

Pattinson, Juliette. Behind Enemy Lines: Gender, passing and the Special Operations Executive in the Second World War. Manchester: Manchester University Press, 2007.

Pattinson, Juliette. "'Playing the daft lassie with them': Gender, Captivity and the Special Operations Executive during the Second World War." European Review of History, 13, no. 2 (2 June 2006): 271-292. DOI: 10.1080/13507480600785955.

Peach, Lucinda J. "An Alternative to Pacifism? Feminism and Just-War Theory." Hypatia 9, no. 2 (Spring 1994): 152-172. https://www-jstororg.libproxy.chapman.edu/stable/3810175.

Perrin, Nigel. "Undercover operators: fakery, passing and the special operations executive." Journal of Intelligence History 16, no. 1 (2017): 23-46. DOI: 10.1080/16161262.2016.1258247.

Odette. Directed by H. Wilcox, H. 1950; United Kingdom: Herbert Wilcox Productions. DVD.

Rose, Sonya O. Which People's War? National Identity and Citizenship in Wartime Britain 1939-1945. Oxford: Oxford University Press, 2003.

Seaman, Mark. Special Operations Executive: A New Instrument of War. London: Routledge, 2006. eBook Collection (EBSCOhost), EBSCOhost (accessed August 4, 2018).

Schippers, Mimi. "Recovering the Feminine Other: Masculinity, Femininity, and Gender Hegemony." Theory and Society 36, no. 1 (February 2007): 85-102.

Shannon, Edgar, and Christopher Ricks. "'The Charge of the Light Brigade': The Creation of a Poem." Studies in Bibliography 38 (1985): 1-44. http://www.jstor.org.libproxy.chapman.edu/stable/40371812.

Sjoberg, Laura. "Women fighters and the 'beautiful soul' narrative." International Review of the Red Cross 92, no. 877 (March 2010): 53-68. 
Solis, Gary D. The Law of Armed Conflict: International Humanitarian Law in War. $2^{\text {nd }}$ Edition. New York: Cambridge University Press, 2016.

Stafford, David. Britain and European Resistance, 1940-1945: A survey of the Special Operations Executive, with Documents. Toronto: University of Toronto Press, 1980.

Stevenson, William. Spymistress: The Life of Vera Atkins, the Greatest Female Secret Agent of World War II. New York: Arcade Publishing, 2011.

The Routledge History of Gender, War, and the U.S. Military. Ed. by Kara Dixon Vuic. London and New York: Routledge, 2018.

Turner, Karen Gottschange and Phan Thanh Hao. Even the Women Must Fight: Memories of War from North Vietnam. New York: John Wiley and Sons 1998.

Tyas, Stephen. SS-Major Horst Kopkow: from the Gestapo to British Intelligence. United Kingdom: Fonthill, 2017.

United States Holocaust Memorial Museum. “Dachau.” Holocaust Encyclopedia. Accessed April 11, 2019. https://encyclopedia.ushmm.org/content/en/article/dachau.

United States Holocaust Memorial Museum. "Ravensbrück.” Holocaust Encyclopedia. Accessed April 11, 2019. https://encyclopedia.ushmm.org/content/en/article/ravensbrueck.

United States Holocaust Memorial Museum. "Ravensbrück: Key Dates.” Holocaust Encyclopedia. accessed April 11, 2019. https:/encyclopedia.ushmm.org/content/en/article/ravensbrueck-key-dates.

Women, militarism, and war: Essays in history, politics, and social theory. Edited by Jean Bethke Elshtain and Sheila Tobias. Savage, Md.: Rowman \& Littlefield, 1990.

Wylie, Neville. "Ungentlemanly Warriors or Unreliable Diplomats? Special Operations Executive and 'Irregular Political Activities' in Europe." Intelligence and National Security 20, no. 1 (2005): 98-120. DOI: 10.1080/02684520500059445. 